National Water-Quality Assessment Program

Prepared in cooperation with the

Maine Center for Disease Control and Prevention

\title{
Assessment of Arsenic Concentrations in Domestic Well Water, by Town, in Maine, 2005-09
}

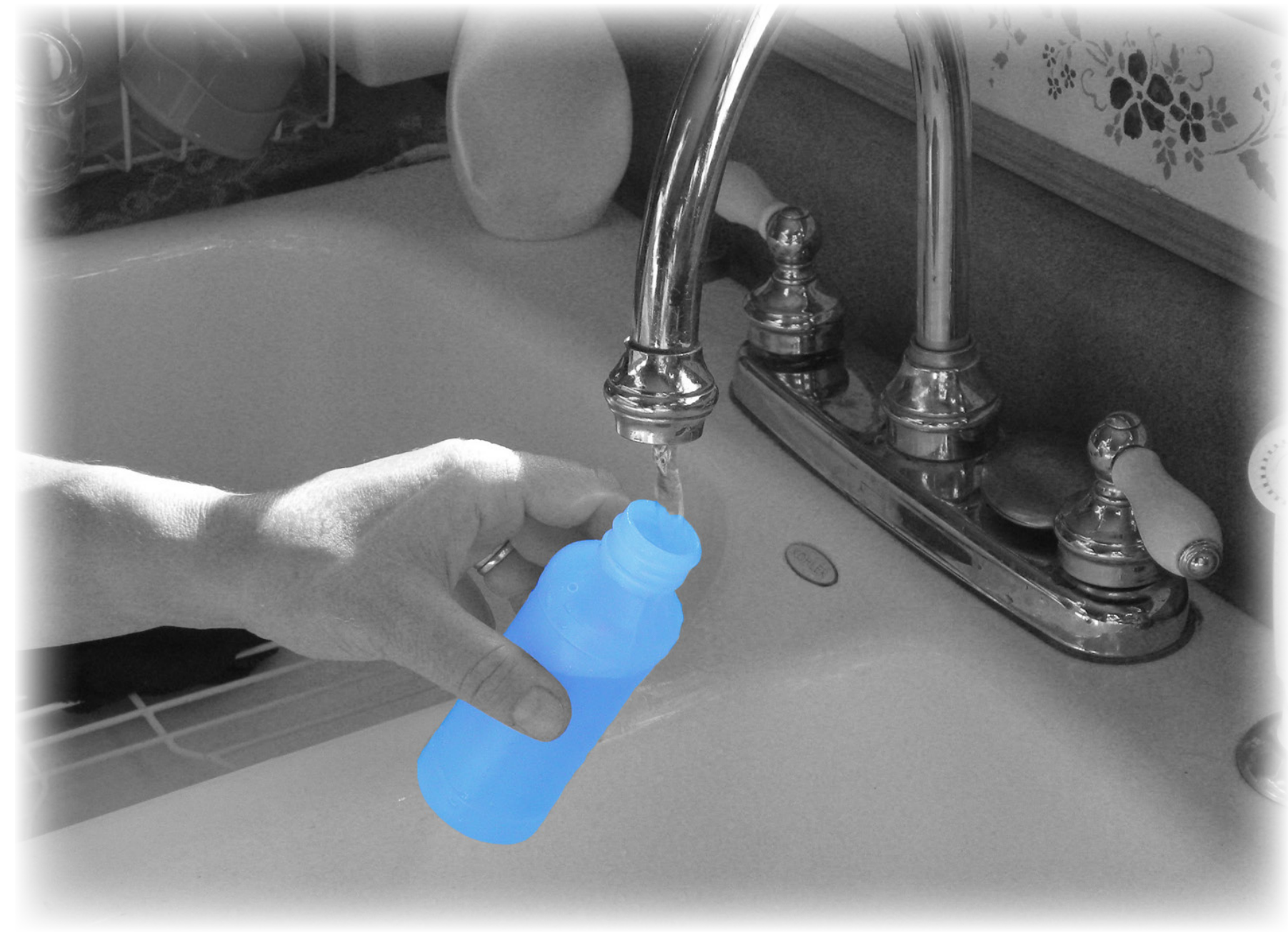

Scientific Investigations Report 2010-5199 



\section{Assessment of Arsenic Concentrations in Domestic Well Water, by Town, in Maine, 2005-09}

By Martha G. Nielsen, Pamela J. Lombard, and Luther F. Schalk

Prepared in cooperation with the

Maine Center for Disease Control and Prevention

Scientific Investigations Report 2010-5199 


\section{U.S. Department of the Interior \\ KEN SALAZAR, Secretary \\ U.S. Geological Survey \\ Marcia K. McNutt, Director}

U.S. Geological Survey, Reston, Virginia: 2010

For product and ordering information:

World Wide Web: http://www.usgs.gov/pubprod

Telephone: 1-888-ASK-USGS

For more information on the USGS - the Federal source for science about the Earth, its natural and living resources, natural hazards, and the environment:

World Wide Web: http://www.usgs.gov

Telephone: 1-888-ASK-USGS

Any use of trade, product, or firm names is for descriptive purposes only and does not imply endorsement by the U.S. Government.

Although this report is in the public domain, permission must be secured from the individual copyright owners to reproduce any copyrighted materials contained within this report.

Suggested citation:

Nielsen, M.G., Lombard, P.J., and Schalk, L.F., 2010, Assessment of arsenic concentrations in domestic well water, by town, in Maine, 2005-09: U.S. Geological Survey Scientific Investigations Report 2010-5199, 68 p. (Also available at http://pubs.usgs.gov/sir/2010/5199.) 


\section{Foreword}

The U.S. Geological Survey (USGS) is committed to providing the Nation with reliable scientific information that helps to enhance and protect the overall quality of life and that facilitates effective management of water, biological, energy, and mineral resources (http://www.usgs.gov/). Information on the Nation's water resources is critical to ensuring long-term availability of water that is safe for drinking and recreation and is suitable for industry, irrigation, and fish and wildlife. Population growth and increasing demands for water make the availability of that water, measured in terms of quantity and quality, even more essential to the long-term sustainability of our communities and ecosystems.

The USGS implemented the National Water-Quality Assessment (NAWOA) Program in 1991 to support national, regional, State, and local information needs and decisions related to water-quality management and policy (http://water.usgs.gov/nawqa). The NAWQA Program is designed to answer: What is the quality of our Nation's streams and ground water? How are conditions changing over time? How do natural features and human activities affect the quality of streams and ground water, and where are those effects most pronounced? By combining information on water chemistry, physical characteristics, stream habitat, and aquatic life, the NAWOA Program aims to provide science-based insights for current and emerging water issues and priorities. From 1991 to 2001, the NAWQA Program completed interdisciplinary assessments and established a baseline understanding of water-quality conditions in 51 of the Nation's river basins and aquifers, referred to as Study Units (http://water.usgs.gov/nawqa/studies/study_units.html ).

In the second decade of the Program (2001-2012), a major focus is on regional assessments of water-quality conditions and trends. These regional assessments are based on major river basins and principal aquifers, which encompass larger regions of the country than the Study Units. Regional assessments extend the findings in the Study Units by filling critical gaps in characterizing the quality of surface water and ground water, and by determining water-quality status and trends at sites that have been consistently monitored for more than a decade. In addition, the regional assessments continue to build an understanding of how natural features and human activities affect water quality. Many of the regional assessments employ modeling and other scientific tools, developed on the basis of data collected at individual sites, to help extend knowledge of water quality to unmonitored, yet comparable areas within the regions. The models thereby enhance the value of our existing data and our understanding of the hydrologic system. In addition, the models are useful in evaluating various resource-management scenarios and in predicting how our actions, such as reducing or managing nonpoint and point sources of contamination, land conversion, and altering flow and (or) pumping regimes, are likely to affect water conditions within a region.

Other activities planned during the second decade include continuing national syntheses of information on pesticides, volatile organic compounds (VOCs), nutrients, trace elements, and aquatic ecology; and continuing national topical studies on the fate of agricultural chemicals, effects of urbanization on stream ecosystems, bioaccumulation of mercury in stream ecosystems, effects of nutrient enrichment on stream ecosystems, and transport of contaminants to public-supply wells.

The USGS aims to disseminate credible, timely, and relevant science information to address practical and effective water-resource management and strategies that protect and restore water quality. We hope this NAWQA publication will provide you with insights and information to meet your needs, and will foster increased citizen awareness and involvement in the protection and restoration of our Nation's waters.

The USGS recognizes that a national assessment by a single program cannot address all water-resource issues of interest. External coordination at all levels is critical for cost-effective management, regulation, and conservation of our Nation's water resources. The NAWQA Program, therefore, depends on advice and information from other agencies_-Federal, State, regional, interstate, Tribal, and local—as well as nongovernmental organizations, industry, academia, and other stakeholder groups. Your assistance and suggestions are greatly appreciated. 



\section{Contents}

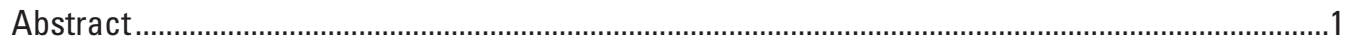

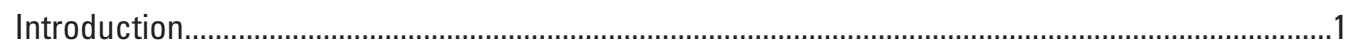

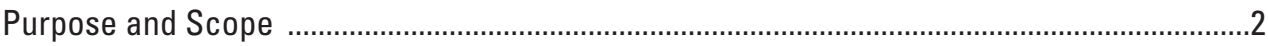

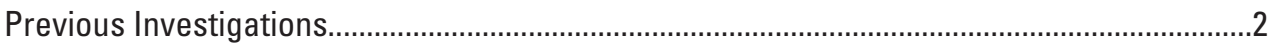

Description of Database, Data Screening, and Statistical Analysis ..............................................

Database of Domestic Well-Water Samples from the Maine Health and Environmental

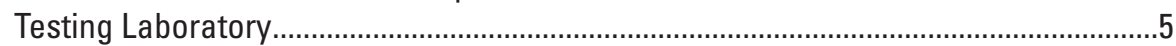

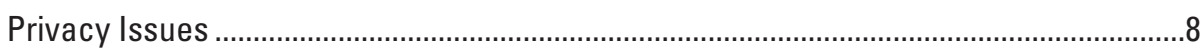

Laboratory Methods and Quality Assurance/Quality Control Methods .........................8

Data Screening and Assumptions about Samples....................................................................

Data Sorting and Elimination of Erroneous Sample Data ..............................................11

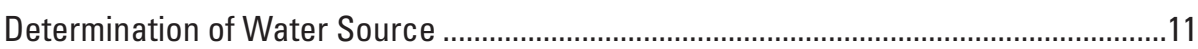

Conversion of Less Than Values to Numeric Values .....................................................12

Handling of Filtered Samples and Multiple Samples per Well........................................12

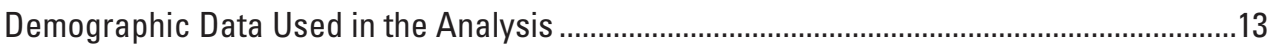

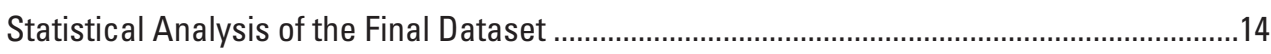

Estimates of Populations and Households Served by Domestic Wells, by Town ............................14

Considerations for Using Domestic Well-Water Data for Town-Wide Summaries of Arsenic

Concentrations in Maine ...................................................................................................

Arsenic Concentrations in Domestic Well Water in Maine..............................................................22

Statistical Distributions of Arsenic Concentrations, by Town ..................................................22

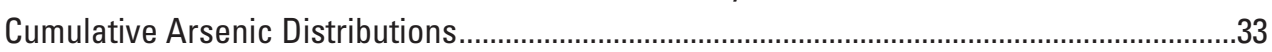

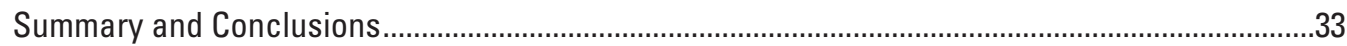

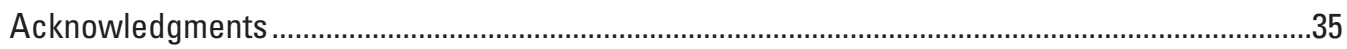

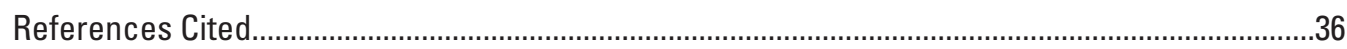

Appendix 1. Demographic Data for Towns in Maine ................................................................38

Appendix 2. Numbers of Samples and Wells with Samples, by Town, in Maine, and Minimum, Maximum, and Median Arsenic Concentrations in Each Town with Samples in the Maine Health and Environmental Testing Laboratory Database, 2005-09...

Appendix 3. Exceedence Percentages for Towns with More than 20 Wells Sampled for Arsenic, from Samples in the Maine Health and Environmental Testing Laboratory Database, 2005-09 


\section{Figures}

1. Map showing towns in Maine with at least one domestic well sample recorded in the Maine Health and Environmental Testing Laboratory database, 2005-09 ...................3

2. Map showing Maine counties and other Maine localities................................................

3. Sample information sheet used by the Maine Health and Environmental Testing Laboratory for submission of samples, 2005-09.

4. Box plots showing distribution of total arsenic concentrations in sample pairs analyzed by the Maine Health and Environmental Testing Laboratory and the Underwriters Laboratory, 2006-07.

5. Graph showing arsenic concentrations in paired samples analyzed by the Maine Health and Environmental Testing Laboratory and Underwriters Laboratory, 2008..........9

6. Graph showing cumulative distribution of arsenic concentrations, by filtration status, in Maine, 2005-09

7. Map showing percentage of town populations using a self-supply water source, generally wells, in Maine, 1990 census

8. Map showing estimated number of self-supplied households, by town, in Maine, 2008

9. Histogram showing distribution of sampling rates for arsenic in Maine towns, 2005-09

10. Map showing sampling rate for towns, calculated as the number of sampled wells per hundred self-supplied households, in Maine, 2005-09.

11. Graphs showing estimated percentage of households with sampled wells in each town in relation to (A) the median of all samples in each town, (B) the maximum of all samples in each town, and (C), the maximum of samples in each town broken down by whether the towns were targeted for outreach by the Maine Centers for Disease Control and Prevention or whether they were unsolicited

12. Map showing total numbers of sampled wells in the Maine Health and Environmental Testing Laboratory database, 2005-09, and some known areas of elevated arsenic levels

13. Map showing maximum arsenic concentrations for towns with five or more sampled wells in Maine, 2005-09.

14. Map showing median arsenic concentrations for towns with five or more sampled wells in Maine, 2005-09

15. Map showing percentage of wells in each town with arsenic concentrations greater than 10 micrograms per liter in Maine, 2005-09.

16. Map showing percentage of wells in each town with arsenic concentrations greater than 50 micrograms per liter, in Maine, 2005-09

17. Map showing percentage of wells in each town with arsenic concentrations greater than 100 micrograms per liter, in Maine, 2005-09.

18. Map showing percentage of wells in each town with arsenic concentrations greater than 500 micrograms per liter, in Maine, 2005-09.

19. Graphs showing cumulative distribution plot types $1(A-B), 2(C-D), 3(E-F)$, and 4 (G-H) for arsenic in wells in Maine, 2005-09. 


\section{Tables}

1. Fields requested from the Maine Human Health and Environmental Testing Laboratory database

2. Fields added to the Health and Environmental Testing Laboratory database for data screening and analysis.

3. Towns with the 30 highest maximum arsenic concentrations, of the towns with five or more sampled wells in the Maine Health and Environmental Testing Laboratory database, 2005-09

4. Towns with the 30 highest median arsenic concentrations, of the towns with five or more sampled wells in the Maine Health and Environmental Testing Laboratory database, 2005-09

5. Towns with the 30 highest percentages of wells with arsenic concentrations exceeding 10 micrograms per liter, of the towns with 20 sampled wells in the Maine Health and Environmental Testing Laboratory, 2005-09, and percentages of wells in those towns with arsenic concentrations exceeding 50, 100, and 500 migrograms per liter

\section{Conversion Factors and Datum}

Inch/Pound to SI

\begin{tabular}{|c|c|c|}
\hline Multiply & By & To obtain \\
\hline \multicolumn{3}{|c|}{ Length } \\
\hline foot $(\mathrm{ft})$ & 0.3048 & meter $(\mathrm{m})$ \\
\hline mile (mi) & 1.609 & kilometer $(\mathrm{km})$ \\
\hline \multicolumn{3}{|c|}{ Area } \\
\hline square mile $\left(\mathrm{mi}^{2}\right)$ & 2.590 & square kilometer $\left(\mathrm{km}^{2}\right)$ \\
\hline
\end{tabular}

Concentrations of chemical constituents in water are given either in milligrams per liter (mg/L) or micrograms per liter $(\mu \mathrm{g} / \mathrm{L})$.

Horizontal coordinate information is referenced to the North American Datum of 1983 (NAD 83). 



\title{
Assessment of Arsenic Concentrations in Domestic Well Water, by Town, in Maine, 2005-09
}

\author{
By Martha G. Nielsen, Pamela J. Lombard, and Luther F. Schalk
}

\section{Abstract}

Prior studies have established that approximately 10 percent of domestic wells in Maine have arsenic levels greater than the U.S. Environmental Protection Agency maximum contaminant limit (10 micrograms per liter $(\mu \mathrm{g} / \mathrm{L})$ ). Of even greater concern are multiple discoveries of wells with very high arsenic levels (>500 $\mu \mathrm{g} / \mathrm{L})$ in several areas of the State. A study was initiated to assist the Maine Center for Disease Control and Prevention (ME-CDC) in developing a better understanding of the statewide spatial occurrence of wells with elevated arsenic levels at the individual town level, identify areas of the State that should be targeted for increased efforts to promote well-water testing, and generate data for potential use in predicting areas of the State likely to have very high levels of arsenic. The State's Health and Environmental and Testing Laboratory (HETL) annually analyzes samples from thousands of domestic wells for arsenic. Results of arsenic analyses of domestic well water submitted to the HETL from 2005 to 2009 were screened and organized, by town, in order to summarize the results for all towns with samples submitted to the HETL. In order to preserve the privacy of well owners, the screening and organization of samples was conducted in the offices of the ME-CDC, following applicable Maine and United States laws, rules, and privacy policies. After screening, the database contained samples from 531 towns in Maine and from 11,111 individual wells. Of those towns, 385 had samples from 5 or more individual wells, 174 towns had samples from 20 or more individual wells, and 49 towns had samples from 60 or more wells. These samples, because they were submitted by homeowners and were not part of a random sample, may not be representative of all wells in a given area. The minimum, maximum, and median arsenic values for the towns with five or more samples were calculated, and the maximum and median values were mapped for the State. The percentages of samples exceeding 10, 50,100, and $500 \mu \mathrm{g} / \mathrm{L}$ were calculated for the 174 towns with 20 or more sampled wells, and statewide maps were prepared for each of these categories. More than 25 percent of the sampled wells in 44 towns exceeded $10 \mu \mathrm{g} / \mathrm{L}$. Many fewer towns had wells with samples that exceeded the 50,100 , or $500 \mu \mathrm{g} / \mathrm{L}$ categories.
For 19 towns, more than 10 percent of the sampled wells had arsenic concentrations that exceeded $50 \mu \mathrm{g} / \mathrm{L}$, and in 45 towns, 1 percent or more exceeded $100 \mu \mathrm{g} / \mathrm{L}$. Of these, Surry in Hancock County had 120 wells tested, and 23 percent of those wells had arsenic concentrations that exceeded $100 \mu \mathrm{g} / \mathrm{L}$, which is a much higher rate than for other towns. In only four towns (Danforth in Washington County, Surry and Blue Hill in Hancock County, and Woolwich in Sagadahoc County), 1 percent or more of the sampled wells had arsenic concentrations greater than $500 \mu \mathrm{g} / \mathrm{L}$ during 2005-09. The distribution of high arsenic concentrations in wells follows some geographic patterns, which are generally geologically controlled. There are clusters or belts of towns with high arsenic concentrations ( $>50 \mu \mathrm{g} / \mathrm{L}$ ), such as in southern coastal areas, the Kennebec County area, and towns along the central coastal part of Maine. In contrast, there are areas of the State with low arsenic concentrations, such as the northernmost towns, as well as towns in the western and west-central areas. There appear to be three distinct large-scale areas of high concentrations of arsenic in groundwater - one in southern coastal areas, one in central Kennebec County, and one in the town of Ellsworth (Hancock County) and the surrounding areas. In addition, several smaller clusters of isolated high concentrations of arsenic in groundwater exist. Earlier testing has identified other clusters of very high arsenic concentrations in groundwater in the towns of Northport, Buxton/Hollis, and Waldoboro, but those samples were collected before 2005 and did not factor in this analysis.

\section{Introduction}

The widespread occurrence of arsenic in groundwater is a well known public health issue in Maine. Arsenic occurs naturally in bedrock in Maine and dissolves into groundwater along bedrock fractures. Arsenic (in the forms of lead arsenate, calcium arsenate, and sodium arsenate) also was widely used as a crop pesticide on apples, potatoes, and blueberries in the early 20th century (D'Angelo and others, 1996). Arsenic has been found in groundwater across Maine in both public watersupply wells and domestic (private) wells at concentrations ranging from less than 0.5 micrograms per liter $(\mu \mathrm{g} / \mathrm{L})$ to more 
than $5,000 \mu \mathrm{g} / \mathrm{L}$, which are some of the highest concentrations reported in the United States (Focazio and others, 1999).

Because of the link between arsenic ingestion and several forms of cancer (primarily bladder and skin cancers), the U.S. Environmental Protection Agency (USEPA) has set the maximum contaminant level (MCL) for arsenic in public water supplies at $10 \mu \mathrm{g} / \mathrm{L}$ (U.S. Environmental Protection Agency, 2001), which was revised downward from the previous MCL of $50 \mu \mathrm{g} / \mathrm{L}$ in 2001. All public water suppliers in Maine are required to test for arsenic and to ensure that water delivered to the public complies with USEPA standards. There are no requirements for homeowners in Maine to test their wells for arsenic.

Public water supplies account for only 52 percent of the drinking water consumed in Maine, however. According to USGS water-use data from 2005, domestic wells account for 20 percent (in Cumberland County) to more than 80 percent (in Washington County) of the drinking water used in Maine (U.S. Geological Survey, 2005). Overall, approximately 40 to 45 percent of the Maine population relies on domestic wells for their drinking water (U.S. Geological Survey, 2005), and most of these domestic wells have not been tested for arsenic. Earlier studies estimated that 12 to 13 percent of Maine's rural population may have wells with arsenic concentrations exceeding $10 \mu \mathrm{g} / \mathrm{L}$ and 1 to 3 percent exceeding $50 \mu \mathrm{g} / \mathrm{L}$ (Loiselle and others, 2001). The study by Loiselle and others (2001) along with other studies elevated the general awareness of the problem of arsenic in domestic well water, and the Maine Department of Health has been aggressively working to encourage Maine residents to test their well water for arsenic. Since 2002, many of the water tests offered by the Maine Health and Environmental Testing Laboratory (HETL) include arsenic as an analyte, removing the prior need for an individual to specifically request and purchase testing for arsenic as an additional analyte. It is believed that this has increased the frequency of testing for arsenic and may possibly lessen the phenomenon of self-selection bias.

The HETL provides water testing services to State agencies and to the general public. Homeowners submit samples (collected using kits and instructions supplied by the laboratory) to the HETL. State agencies that test domestic wells, monitoring wells, and public supply wells also use the HETL for water-testing services. Over the years, the HETL has analyzed tens of thousands of arsenic samples from homes across Maine, but the data have not been rigorously organized and assembled for scientific or public-health analyses. In 2009, the Maine Center for Disease Control and Prevention (ME-CDC) began a cooperative program with the USGS to retrieve, organize, screen, and analyze these data, to be used by the ME-CDC to develop a better understanding of the statewide spatial occurrence of wells with elevated arsenic levels at the individual town level, to identify areas of the State that should be targeted for increased efforts to promote well-water testing, and to generate data for potential use in predicting areas of the State likely to have very high levels of arsenic.

\section{Purpose and Scope}

The purpose of this report is to describe the steps taken to retrieve, screen, edit, and analyze arsenic data for domestic well water that have been compiled by the HETL and to describe the distribution of domestic wells with elevated levels of arsenic in towns having samples from at least 20 wells. The data span the period from January 2005 through July 2009 and include samples from domestic wells submitted by homeowners and by State agencies. This report describes the sample submission, sample data forms, procedures for maintaining homeowner privacy, and quality assurance of the database and laboratory analyses. Assumptions made about incomplete data, handling of multiple samples for a well, potential for self-selection bias, and the handling of "filtered" samples also are described. The second part of the report presents the descriptive analysis of the dataset once all screening steps had been completed, including the numbers of sampled wells in each town; the minimum, median, and maximum arsenic concentrations found in each town (for towns with 5 or more sampled wells); and the percentage of wells in each town with arsenic levels greater than 10, 50, 100, and $500 \mu \mathrm{g} / \mathrm{L}$ (for towns with 20 or more sampled wells). The towns in Maine with at least one well sample recorded in the database are shown in figure 1. Cumulative distribution plots of the data in several representative towns are presented, along with several maps of the State showing the spatial distribution of the samples and of arsenic occurrence.

\section{Previous Investigations}

The presence of high levels of arsenic (more than $50 \mu \mathrm{g} / \mathrm{L}$ ) in domestic wells in Maine became recognized in the early 1990s when the Maine Geological Survey (MGS) and other State agencies published a report documenting high arsenic levels in domestic wells in the Buxton/Hollis area in southern Maine (see fig. 2) and the occurrence of relatively high arsenic levels in other areas of Maine (Marvinney and others, 1994). This study showed that the problem was not confined to a few towns in southern Maine but that high arsenic levels occurred in many geologically diverse areas across the State (Marvinney and others, 1994). Shortly thereafter, the USGS and others began analyzing data from public supply wells in Maine and New Hampshire, selected domestic wells, and stream sediments (Ayotte and others, 1999; Peters and others, 1999; Ayotte and others, 2003; Ayotte and others, 2006; Robinson and Ayotte, 2006; Peters, 2008) and concluded that there is a strong spatial correlation between the presence of arsenic in well water and the presence of certain bedrock geologic units (Robinson and Ayotte, 2006). Although arsenical pesticides applied throughout the region in the 1900s could not be ruled out as a source in some areas, it did not appear to be a controlling factor in the overall presence of bedrock groundwater arsenic (Ayotte and others, 2006). A joint study by the MGS and ME-CDC is the only Maine study 


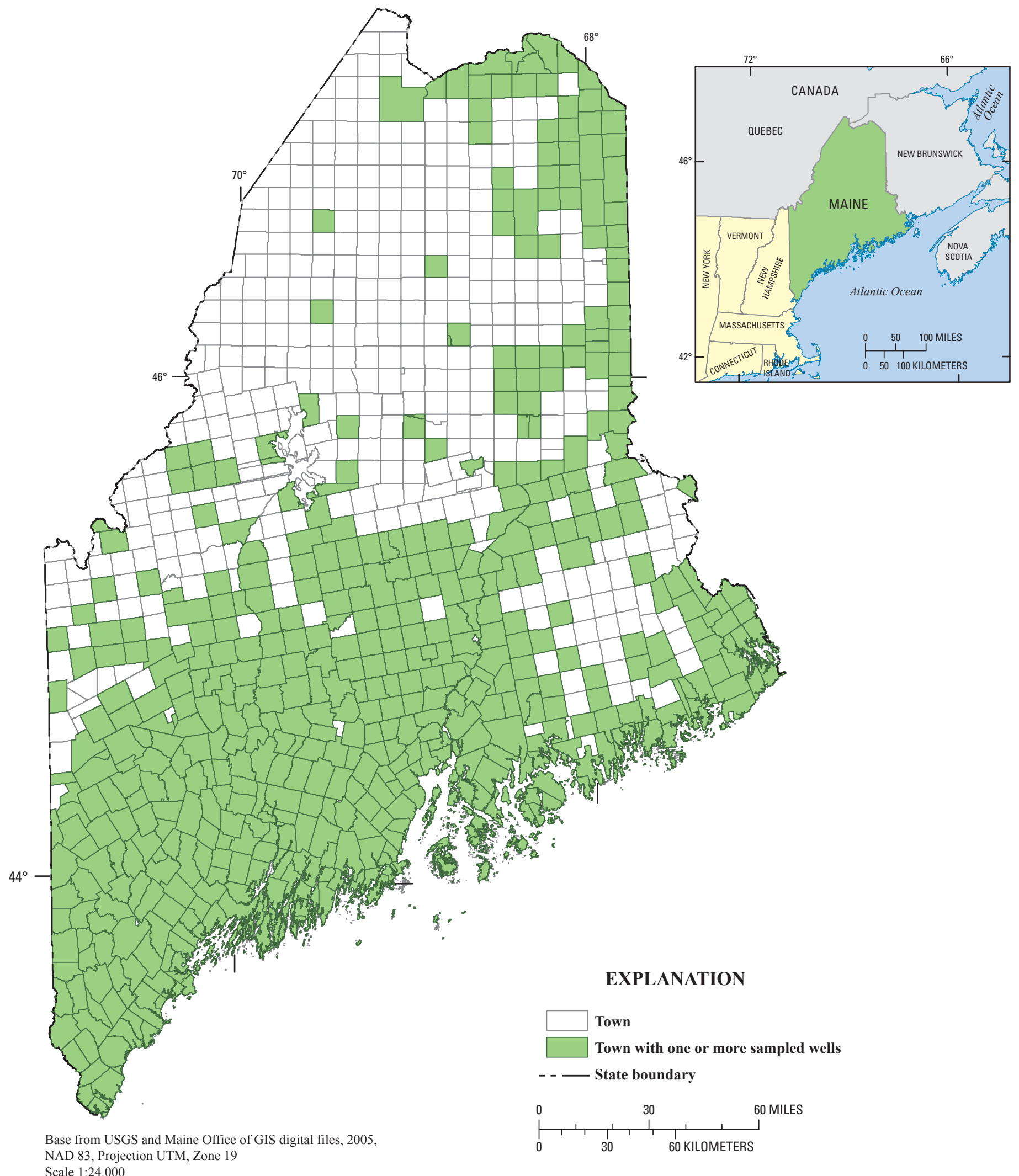

, Projection UTM, Zone 19

Scale 1:24,000

Figure 1. Towns in Maine with at least one domestic well sample recorded in the Maine Health and Environmental Testing Laboratory database, 2005-09. 


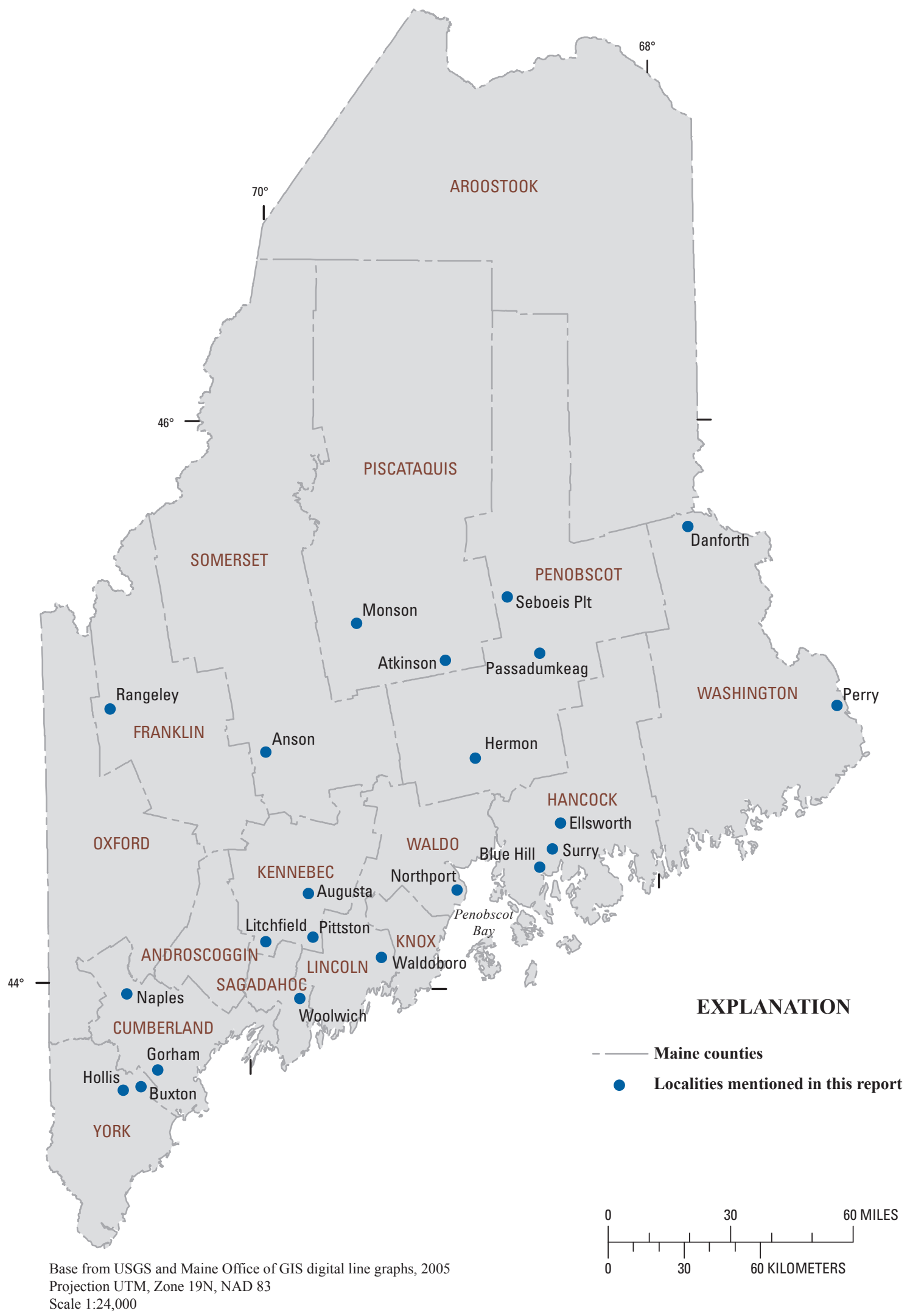

Figure 2. Maine counties and other Maine localities. 
that used a random-sampling design to support estimates of population exposure to arsenic in well water (Loiselle and others, 2001). This study reported that 10 percent of sampled wells in Maine had arsenic levels of $10 \mu \mathrm{g} / \mathrm{L}$ or higher.

Studies have shown that the occurrence of high levels of arsenic in Maine appears to be highly clustered in areas from a few kilometers to tens of kilometers across (Loiselle and others, 2001; Yang and others, 2009). Arsenic clusters have been identified in several coastal and inland areas of Maine, particularly in the Buxton/Hollis area in southern Maine (Marvinney and others, 1994), the Waldoboro area in central coastal Maine (Sidle and others, 2001; Sidle, 2003), the greater Augusta area (Yang and others, 2009), the Northport area on western Penobscot Bay, (Lipfert and others, 2006), the Ellsworth/Blue Hill area (Andrew Smith, ME-CDC, oral commun., 2008), the town of Rangeley in northwestern Maine (Andrew Smith, ME-CDC, written commun., 2009), and Danforth in far eastern Maine (Andrew Smith, ME-CDC, written commun., 2008). Some of the clusters of wells with high concentrations of arsenic encompass several towns, and maximum arsenic concentrations are in hundreds of micrograms per liter (southern Maine, greater Augusta area, and Ellsworth/Blue Hill). Other clusters encompass much smaller geographic areas but have maximum arsenic concentrations in thousands of micrograms per liter (Northport and Danforth, for example).

These small, extreme-concentration clusters within the State continue to be discovered; the most recent is the 2008 discovery of a cluster of wells in Danforth with arsenic levels of 1,000 to 3,000 $\mu \mathrm{g} / \mathrm{L}$ (Andrew Smith, ME-CDC, oral commun., 2008). There is an understandable desire by public health agencies to identify other areas of the State likely to have other extreme-concentration clusters, so outreach efforts can be better targeted. There is also a desire to understand in which towns in the State there has been considerable testing for arsenic in well water and in which there have not. A systematic compilation and analysis of the large domestic well-water dataset available from the HETL, which consists of thousands of records from water tests for arsenic, was viewed as potentially helpful in meeting these needs.

\section{Description of Database, Data Screening, and Statistical Analysis}

A detailed description of the data screening methods is provided in this report because the HETL dataset is an opportunistic dataset, which means that data were neither collected nor stored with any intent or subsequent plans for retrieval and analysis to support investigations. The purpose of the data screening exercise was to reduce the database to one sample per well that represented, as well as possible given the information available, untreated or "raw" groundwater from that well.

\section{Database of Domestic Well-Water Samples from the Maine Health and Environmental Testing Laboratory}

The database used for this analysis was compiled from the results of water samples submitted for analysis by homeowners; by real estate agents (for clients); and by a few State agencies, including the Maine Department of Transportation, Maine Department of Health and Human Services-Bureau of Child and Family Services, and the Maine Department of Environmental Protection. Samples were analyzed for arsenic at the HETL in Augusta. A large proportion of the samples was sent to the laboratory for general water tests, which have all included arsenic since 2002. Test kits for water analysis were provided by the HETL to those requesting analyses; the kits consist of instructions for collecting samples, sample bottles, boxes for mailing the samples to the HETL, and a sample identification sheet to be filled in by the person requesting the sample analysis. Test kits may be picked up in person at the HETL, but most often the HETL mails the test kit to the person requesting the sample analysis. These kits also can be ordered online through the State of Maine Website. A sample kit includes a clear polyethylene sample bottle with no preservative. Sample tracking is conducted using a barcode label on the bottle and a corresponding barcode on a label affixed to the sample information sheet. Instructions for collecting samples of drinking water direct the homeowner to run the water from a tap (usually a kitchen sink) for 5 to 10 minutes before filling the bottle. After filling the sample bottle and completing the sample identification sheet (fig. 3), the test kit is returned to the HETL (by mail or in person). The instructions, which are the same for most water tests offered by the HETL, state that the sample is to be sent to the HETL on the same day that it is collected and that the sample is not to be collected and sent on a Friday or Saturday. After arriving at the HETL, the sample is logged in using the sample identification sheet and barcode, the sample is acidified with nitric acid to a $\mathrm{pH}$ of less than 2, and the sample analysis is begun usually within 24 hours (John Nims, Maine Health and Environmental Testing Laboratory, written commun., 2010).

The database into which the samples are logged has specific fields for much, but not all, of the information contained in the sample information sheet. The client name, address, town, state, zip code and address are entered, along with the date and time of sample collection, person collecting the sample, sample location (town or city), sample state, and zip code of sample location. As the person collecting the sample may not always be the client (the party paying for the sample analysis), this information is important in determining where the sample came from. Also recorded are whether the sample is from a public source or private home, the sample type, company name (if given - often this field is filled in with "cash client" or "walk-in client"), and sample description. The sample description field is a catchall field and includes 
See back for sampling instructions and when to expect laboratory results

DEPARTMENT OF HEALTH \& HUMAN SERVICES

HEALTH \& ENVIRONMENTAL TESTING LABORATORY DATE REC'D @ LAB

TEL: (207)287-1716 FAX: (207) 287-1884

TEMP UPON ARRIVAL @ LAB $\mathrm{C}$

( ) NAME AND ADDRESS (IF NOT ON LABEL)

( ) CHANGE OF NAME OR ADDRESS

IF YOU HAVE REMOVED THIS

LABEL, PUT IT BACK. IT NEEDS

TO STAY WITH THIS FORM

NAME:

STREET:

TOWN:

ZIP CODE:

PHONE (EVE):

PHONE (DAY):

FAX

\section{( ) PLEASE CHECK HERE IF YOU WOULD LIKE A SIMPLIFIED FINAL REPORT}

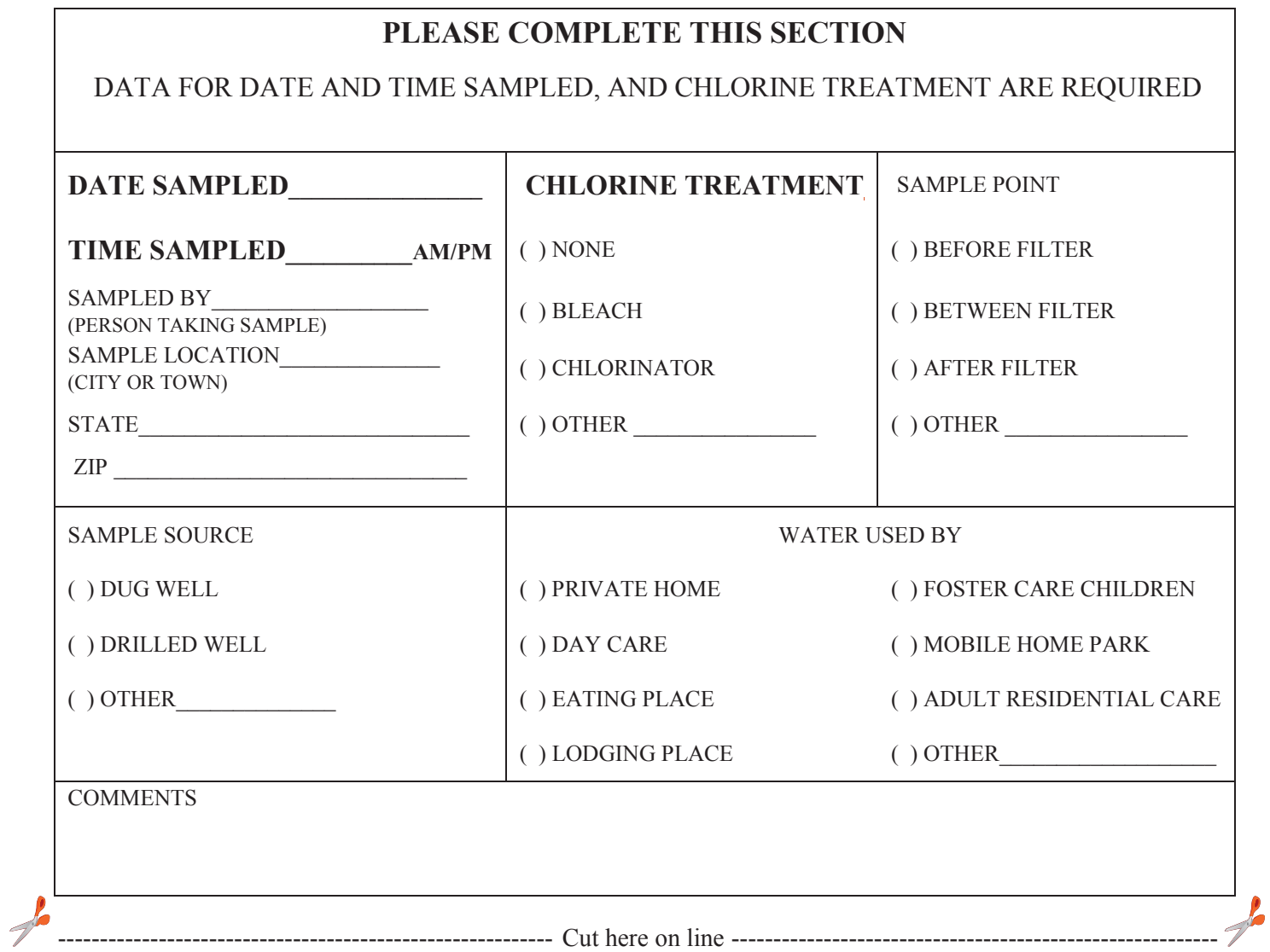

WRITE YOUR SAMPLE NUMBER FROM THE BARCODED LABEL ABOVE FOR YOUR RECORDS EXAMPLE: C123456 DO NOT REMOVE BARCODED LABEL FROM THIS FORM OR BOTTLES

PLEASE WRITE YOUR SAMPLE NUMBER HERE

Figure 3. Sample information sheet used by the Maine Health and Environmental Testing Laboratory for submission of samples, 2005-09. 
information on sample-collection point (before or after filter), sample source (if "other" was checked on the form), other treatment or filtration information, anything in the "comment" field, and often the name and address of the house from which the sample was collected if the client was not a homeowner.

All these data are associated with each arsenic sample in the HETL database. Each sample result in the database has a unique Analyte field and associated Result field. For this study, the authors requested a compilation of all the HETL data from January 1, 2005, to July 20, 2009, for which the
Analyte field was arsenic, the Result included a numerical value (including non-detects), the Sample State was Maine, the Public/Private field was either private or blank, and the Sample Type was either drinking water or blank. The fields for each record requested from the HETL are shown in table 1.

From this initial set of data, the authors screened, sorted, re-categorized the information, and stripped out all personally identifiable information (PII) to create the database that was used in the final analysis. The procedure for doing these tasks is described in the following sections.

Table 1. Fields requested from the Maine Human Health and Environmental Testing Laboratory database.

[HETL, Health and Environmental Testing Laboratory]

\begin{tabular}{|c|c|}
\hline Field & Description \\
\hline Sample Number & Unique sample number used by HETL \\
\hline Profile/test & Analyte code requested for sample \\
\hline Analyte & Arsenic \\
\hline Results, units & Numeric result, or less than value, and units (primarily micrograms per liter) \\
\hline Sample Date & Date sample was collected \\
\hline Client Name & Name of person requesting sample \\
\hline Client Address & Address of person requesting sample \\
\hline Client Town & Town of person requesting sample \\
\hline Client State & State of person requesting sample \\
\hline Client Zip & Zip Code of person requesting sample \\
\hline Sampler & Person collecting the sample, often the same as the client \\
\hline Sample Location & Location (town, city) in which the sample was collected \\
\hline Sample State & State in which the sample was collected \\
\hline Sample Zip & Zip code of sample location \\
\hline Public/Private & Use of water: public well or private well \\
\hline Sample Type & DW-H2O (drinking water) or blank \\
\hline Company Name & "Cash clients," "walk-in clients," or company/agency name \\
\hline Sample Description & Catch-all field for notes, well type, filtration information, or any other information \\
\hline
\end{tabular}




\section{Privacy Issues}

Parties submitting samples to the HETL have a reasonable expectation that their information will remain private and confidential under the Privacy Act of 1974, as amended in 1988 (5 U.S.C. §552a). However, the screening and sorting of the data required the use of PII, such as the names and street addresses, in order to identify samples taken from the same source. Under Maine State Law (22 MRSA §1692-B.), the ME-CDC is given access to all reports and records filed by physicians, hospitals, or other private- or public-sector organizations with all departments, agencies, commissions or boards of the State for the purpose of conducting investigations within the department's disease surveillance programs. This statute thus provides authorization for ME-CDC to have access to private well-water data in HETL's possession. The statute also requires that the department follow the data confidentiality requirements of the departments, agencies, commissions or boards of the State that provide this information (including the HETL). Therefore, all screening work of these data was conducted by the USGS within the ME-CDC offices, using ME-CDC computers, and following all the ME-CDC confidentiality requirements and United States laws. Once the screening was completed, all PII was removed from the database, and this version was used by the USGS in subsequent analyses. Town names and an arbitrary number representing each unique source remained with each sample.

\section{Laboratory Methods and Quality Assurance/ Quality Control Methods}

At the HETL, drinking-water samples are analyzed for metals (including arsenic) following USEPA method 200.8 , using inductively coupled plasma/mass spectrometry (ICP/MS). Because the homeowner sample kits contain no preservative, all samples for arsenic analysis received by the HETL are first treated with high purity nitric acid in order to adjust the $\mathrm{pH}$ of the samples to less than 2 prior to sample analysis by ICP/MS.

An assessment of HETL arsenic analyses was derived from a 2006-07 comparison of arsenic concentrations reported by HETL and the Underwriters Laboratory (UL; Underwriters Laboratories, Inc., Drinking Water Laboratory, South Bend, Ind.) as part of a project to review the efficacy of treatment systems in removing arsenic from domestic well water (Charles Culbertson, U.S. Geological Survey, written commun.). During that project, 64 samples from wells with concentrations of arsenic ranging from 5 to $420 \mu \mathrm{g} / \mathrm{L}$ were replicated (sampled at the same time, from the same source, and using USEPA method 200.8; samples acidified to $\mathrm{pH}<2$ for both laboratories) and sent separately to HETL and UL. The results of the analyses for total arsenic from the two laboratories were compared to assess quality assurance in the analytical process.

The distributions of total arsenic concentrations in the paired samples from the two laboratories (fig. 4) were similar, and the overall differences in the distributions were slight. The mean concentration of total arsenic analyzed by HETL was $97.3 \mu \mathrm{g} / \mathrm{L}$ ( standard error $=11.1 \mu \mathrm{g} / \mathrm{L}$ ), whereas the mean concentration of total arsenic analyzed by UL was $98.0 \mu \mathrm{g} / \mathrm{L}$ (standard error $=11.9 \mu \mathrm{g} / \mathrm{L}$ ). Neither dataset is normally distributed (Shapiro-Wilk method, Shapiro and Francia, 1972).

In general, the average difference in concentration for the 64 sample pairs analyzed by HETL and UL, expressed as the absolute value of the relative percent difference between the samples, was about 7.6 percent (|[HETL-UL]/ $\left.\left.([\mathrm{HETL}+\mathrm{UL}] / 2)\right|^{*} 100\right)$. A comparison of concentrations for the paired samples (fig. 5) shows that, for the most part, this difference is primarily at the upper end of the range in concentrations of total arsenic (with one exception at the lower end of the range). The range in relative percent difference is 0 to 105 percent, but only two samples have a relative percent difference greater than 16.7 percent. The best-fit line through the data points has an $r^{2}$ of 0.983 . According to a one-way analysis of variance of the datasets, the concentration means are not significantly different at the $p=0.05$ level.

\section{Data Screening and Assumptions about Samples}

After receiving all the requested data from HETL, several data screening, sorting, and coding tasks were completed. The purpose of the data screening was to reduce the dataset to samples collected from domestic wells that represented "raw" groundwater, or at least groundwater that was not treated to remove arsenic. Furthermore, the intent was to compile statistics, by town, on wells (not on samples) so that one well sampled many times did not skew the town statistics. The screening/sorting/coding tasks included (1) screening out duplicate samples; (2) determining the minor civil division (town) in which the sample was collected; (3) screening out samples that were probably not domestic well-water samples, even though they passed an initial data screening step; (4) determining which samples in each town probably were either repeat samples from the same well or a unique sample from a well; and (5) documenting what was known about any possible filtration of the water sample.

Several new fields were created in the database to hold information gleaned from the original list of fields. These fields are listed in table 2. 


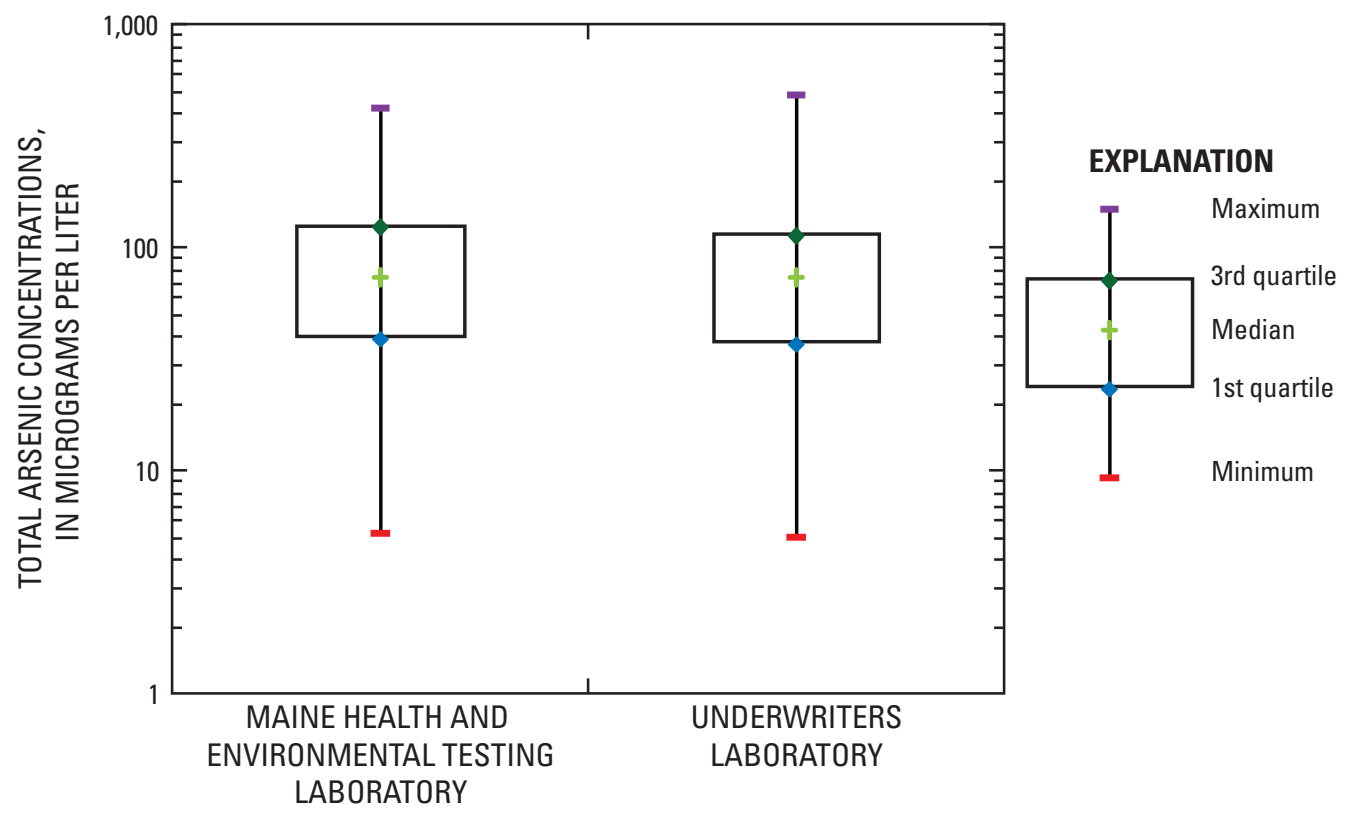

Figure 4. Distribution of total arsenic concentrations in sample pairs analyzed by the Maine Health and Environmental Testing Laboratory and the Underwriters Laboratory, 2006-07.

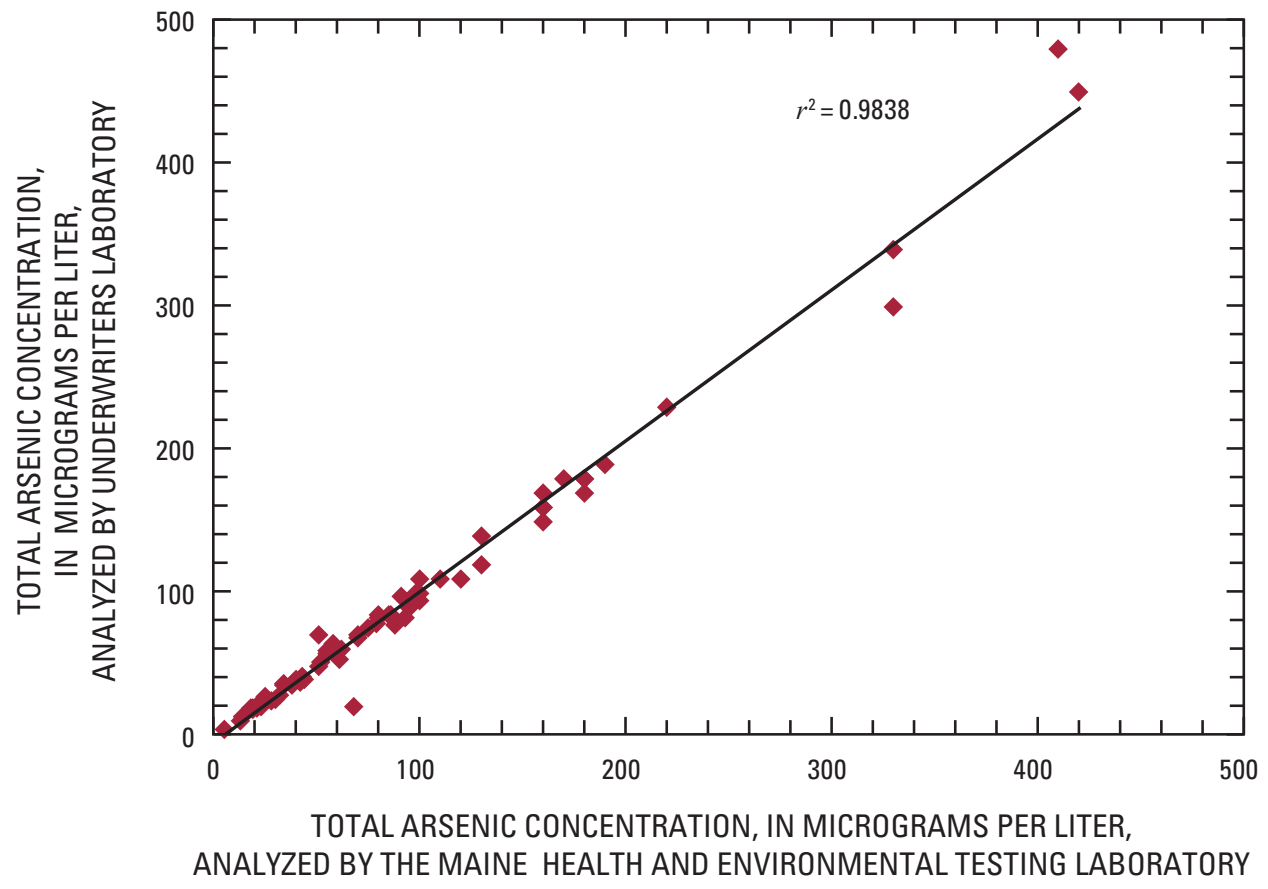

Figure 5. Arsenic concentrations in paired samples analyzed by the Maine Health and Environmental Testing Laboratory and Underwriters Laboratory, 2008. 
Table 2. Fields added to the Health and Environmental Testing Laboratory database for data screening and analysis.

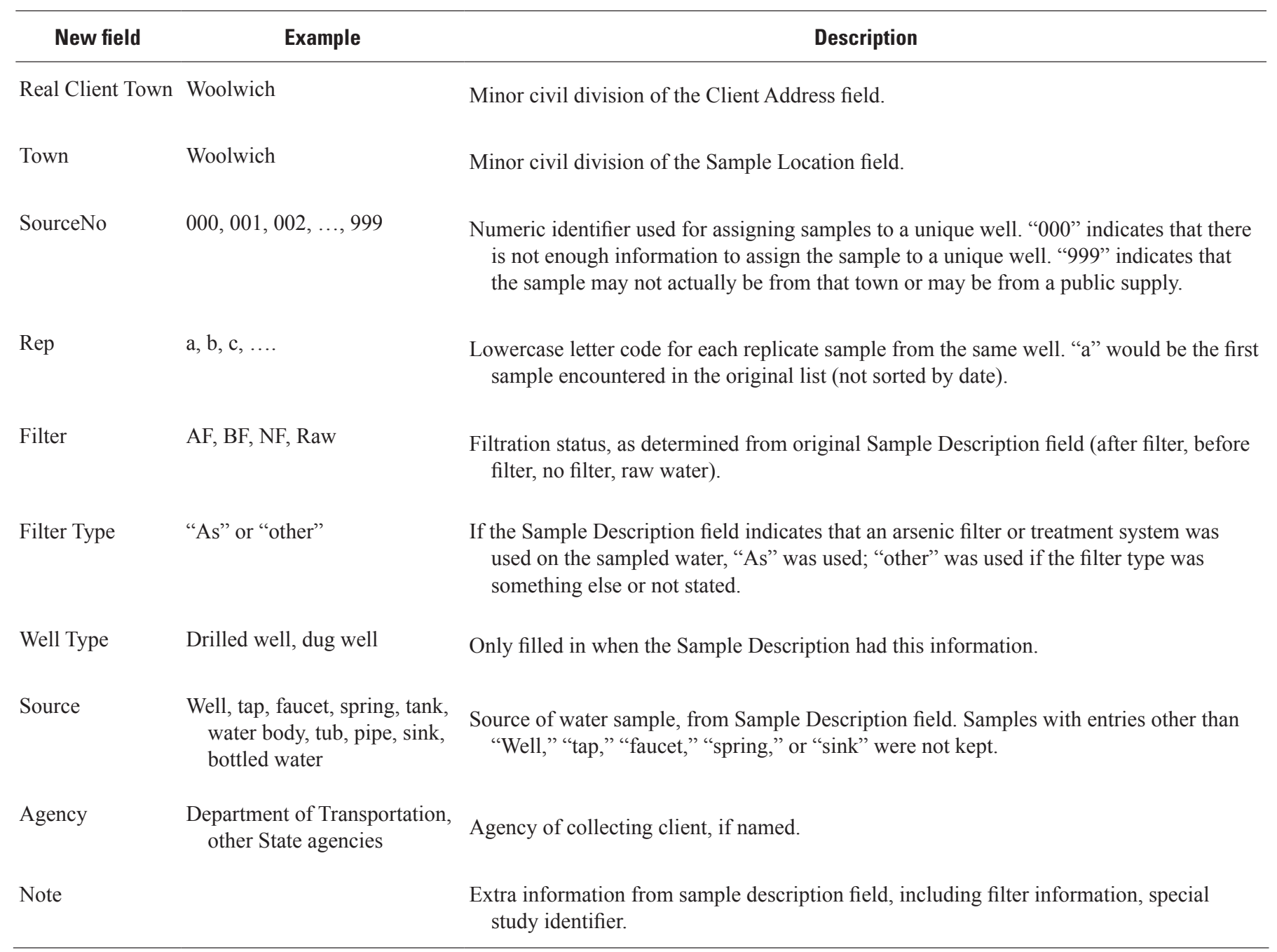




\section{Data Sorting and Elimination of Erroneous Sample Data}

The original request for data from HETL produced 18,009 records. The initial screening found 3,765 duplicated Sample Numbers; these records were removed from the database. Next, the Sample Location field was parsed through a lookup table to sort out the Town (minor civil division) in which minor localities were located. Misspellings and typographical errors in the place name were corrected during this step. If a misspelling of a place name or town had an ambiguous solution (could be corrected to more than one specific town), this record was discarded. Several locations of samples were found to be outside Maine, even though they were tagged as being in Maine, and these records were discarded. Although the data requested from the HETL was for domestic well-water data, sometimes samples were coded incorrectly, and information in either the Client or Sample Description fields indicated that the water was from a public supplier, institution, or other water source, such as a pond or stream, or was purchased (bottled) water. These records also were removed from the database. The final number of records passing the screening tests was 14,175 .

\section{Determination of Water Source}

The most difficult part of the data screening was the determination of whether a particular water sample was from a unique well in a given town. The general procedure involved an examination of the fields Town, Sampler, ClientName, ClientAddress, Real Client Town, Company Name, and Sample Description. Each town was screened individually (531 towns are represented in the database with 1 to 217 individual wells sampled in each). The data were sorted first by the Sampler field, and each unique "sampler" was given a SourceNo $(001,002, \ldots 00 x)$, which became the tentative unique well number. These were then compared to the Client Name and Client Address fields to see if other samples with different samplers were likely to be from the same location. For example, in town X, John Southman collected sample 1 and was also the Client. Judy Southman collected sample 2 and was the Client, but John and Judy shared an address and probably were related. Therefore, the samples were probably from the same well. Sample 3 was collected by Alan Southman, but the Client was John Southman, and the address had the same street name as samples 1 and 2 (but no number), so sample 3 was assumed to be from the same well as samples 1 and 2. Sample 4 was collected for the Maine Department of Transportation by a State employee, but the Sample Description has "John Southman well," so the sample was assumed to be from the same well as samples 1,2, and 3. (This was done only if the name was a full name and not a common name.) A substantial amount of subjective judgment was used in the determination of the SourceNo field, and because the street address of the sample location was not requested on the sample information sheet, there is inherent uncertainty in this determination. Therefore, caution was used in assigning multiple samples to a unique SourceNo. If there was reasonable ambiguity about whether the sample could be assigned to a unique well, it was given a SourceNo of "000" and not used in the subsequent analysis. (In late 2009 the HETL changed the sample information sheet and now requests the address of the sample location. This will greatly simplify this process in the future). Additional assumptions made in this screening step are listed below.

1. If the sampler was the same for two or more records, and there were no data to indicate otherwise, it was generally assumed that the sample came from the same source, even though this may not in fact have been the case (except for samples collected by State agencies or real estate agents; see below). For example if Joel sampled his parents' well across the street but wrote himself down as "sampler" for both his own sample and his parents' sample, there was no way to distinguish these two samples by source since the sample location as well as all client information would match. In cases where two samplers were the same but their client names were different, the record with matching client name and sampler was given a unique number, and the record with nonmatching client name and sampler was given a SourceNo of 000 because there was not enough information to confirm replication.

2. The address of the sample location was not requested on the sample information sheet until late 2009. The authors made assumptions about the sample address based on Sample Location (city or town), Client Address (this should be a street address), Sampler, and Client Name.

3. Post Office boxes were used, if available, to determine whether a source (well) was unique, even though the well could not be pinned to a location. In some instances, one Sampler or Client Name was linked to a street address in one record and a post office box in another; it was assumed in these cases that both samples were replicates from the same source.

4. If the Sample Location field was blank, the sample was not collected by an agency, and there was unique PII in the client fields, it was assumed that the Client Town and Client Address were the same as the sample town and address.

Several agencies, particularly the ME-CDC and Maine Department of Transportation (DOT), collected samples in various towns, but the Client Name and Client Address were always in Augusta, and the sampler was always a State employee. Therefore, unless the Sample Description contained enough site-identification information, the records were marked "000" in SourceNo. If the Sample Description did contain PII, that information was compared to other samplers, client names, and client addresses in that town 
to check for replicates. Often the PII was a last name with or without a first name or initial, and some names were found repeatedly within that agency's samples from that town. If the names could be linked to, or distinguished from, those of other records with any certainty (first and last names were consistently the same, for example), they were given nonzero SourceNo's; otherwise, the records were marked " $000 . "$ Sometimes the agency comments consist of information such as "New well—John Southman." If there were multiple samples, some before and some after the new-well comment, it was assumed that the samples were from different wells on the same property (particularly if the arsenic values were quite different).

\section{Conversion of Less Than Values to Numeric Values}

The Result field in the original data was populated with numeric values if the arsenic values were greater than the detection limit, or a less than 0.5 value if arsenic was not detected. These less-than values were recoded for data analysis and were converted to a value of 0.1 for graphing and data summary statistics. When the summary statistics were calculated, if a median value fell between a value at the detection limit and one below the detection limit, the median was set to less than 0.5 .

\section{Handling of Filtered Samples and Multiple Samples per Well}

The stated goal of using samples that represented "raw" groundwater, or at least groundwater that was not treated to remove arsenic, determined how the available information on water treatment or filtration was utilized, particularly when deciding how to aggregate multiple samples per well to one representative value. Any available information on water treatment/filtration for each sample (in the sample description field) was distilled into the field Filter (coded as YES, NO, or UNK for unknown). Forty-eight percent of the total samples had no information on whether the sample had gone through some kind of treatment or filter. Of the rest, 54 percent were noted as being untreated, and 46 percent had been collected after some sort of filter or treatment system. Once again, some judgment was needed in determining what to use for the Filter field because the comments in the sample description field were often vague. Even where the description indicated that a sample was collected after a filter, there was rarely information about the type of filter (for example, chlorine filter, sediment filter, or reverse osmosis filter). If a sample record did not contain "After Filter" or "AF" in the Sample Description field but did contain the name of a type of filter, such as just the word "anion," it was assumed that the sample was indeed collected after the filter of the given type. Where a determination could be made that a sample was filtered, the Filter field was set to YES. If the information indicated that the sample was definitely not filtered or treated, the field Filter was filled in with NO.

An analysis of how the filtration status (as determined above) affected the arsenic concentration in the samples was conducted to both determine how to handle multiple samples at a given well and whether to keep or discard all the sample records marked "Filtered." The variation in arsenic concentration at any given well in the dataset may be the result of natural variation or the use of a treatment system in the home (or a combination of both). Because many of the water-treatment systems and filters installed in homes do not affect arsenic concentrations appreciably, the authors did not want to discard data for all 3,263 samples that were tagged as "Filtered" unless the data indicated that the samples were in some way different from the other arsenic samples. To assist in determining the best strategy for dealing with these Filtered samples, the authors created cumulative distribution graphs of the data in the Filter categories (YES, NO, or UNK) (fig. 6).

Figure 6 shows that the samples described as unfiltered (NO) have a slightly different distribution than the samples that were described as filtered/treated (YES) and the samples for which no information was available (UNK). The unfiltered samples generally have slightly higher arsenic concentrations than the other two types up to the 98th percentile, which is not surprising. The samples described as filtered and samples with filter unknown (UNK) have similar distributions and are essentially identical at concentrations greater than $3 \mu \mathrm{g} / \mathrm{L}$. Many of the filter unknown samples probably do have some sort of treatment because the distribution is so similar to that of the Filtered samples. This indicates that while many filters or treatment systems that are not intended to treat for arsenic do in fact affect the arsenic concentrations somewhat. However, because this study is primarily concerned with identifying towns that have wells with high arsenic concentrations $(>50 \mu \mathrm{g} / \mathrm{L})$, there seemed to be little basis for discarding all the samples described as filtered (YES) from the overall dataset. There were 195 samples in the dataset that were described as being treated for arsenic specifically, and these were removed from the analysis.

There were several options for handling these multiple samples from a well: average the values to get a composite concentration, take the sample that was collected first because first samples often had the highest concentrations and were used to determine whether a treatment system was necessary (subsequent samples often were collected to test the efficacy of a treatment system) or select one sample (unfiltered if possible) from each well. If all the variations in arsenic concentrations for a well were the result of natural variation, taking the average would result in a representative concentration for that well. For the wells with multiple samples, however, it was common to have some samples filtered and some not. Oftentimes, the first sample in the dataset for a well was high in arsenic concentration, and a later sample would be tagged as filtered and be less than the detection level (or it may not have been tagged as filtered although it was less than the detection level anyway). 


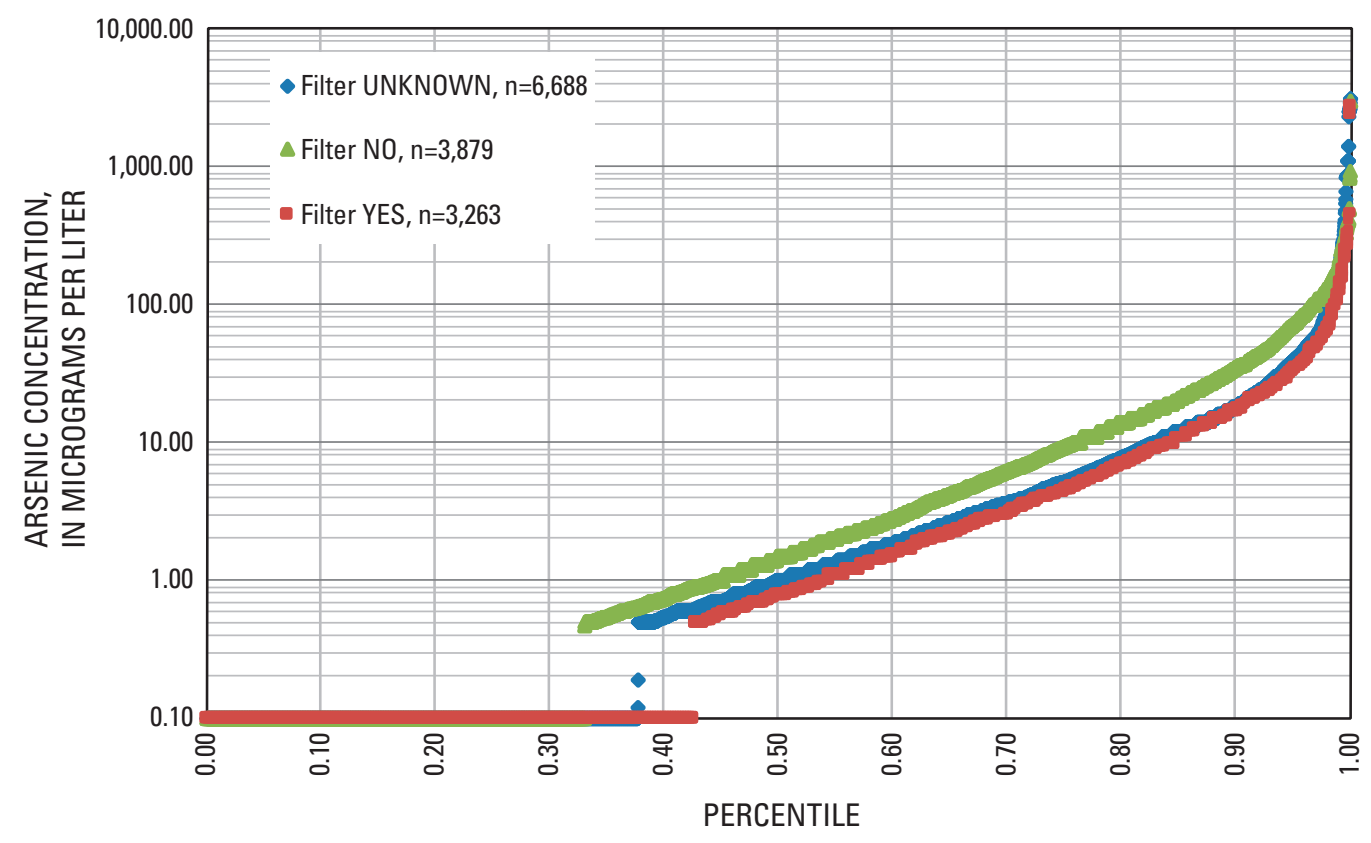

Figure 6. Cumulative distribution of arsenic concentrations, by filtration status, in Maine, 2005-09.

Many times, Before Filter and After Filter samples were collected on the same day. Because of the mix of filtered and unfiltered samples (and not knowing necessarily which was which), the most conservative and simple approach was to take the maximum concentration at each well. This was most likely to catch all the samples described as unfiltered, as well as unknown samples that were not treated/filtered.

Overall, 16 percent of the wells had from two to six samples, the remaining 84 percent had only one sample. On the basis of the analysis described above, the wells with multiple samples were given one value representing the maximum concentration at that well. The final dataset consisted of one value for each of the 11,111 wells.

\section{Demographic Data Used in the Analysis}

Demographic data were used to put the number of sampled wells in each town into context, specifically, to compare the number of wells sampled to the estimated number of self-supplied households. Population data are available for all the organized towns in Maine (488), but there are an additional 420 unorganized minor civil divisions (plantations, surpluses, unorganized townships) for which individual population estimates are not available. (The census combines these into blocks of unorganized territories for demographic data.) Seven of the minor civil divisions that have arsenic data in this study have no individual census population estimates, so those areas were left out of the demographic analyses described later in the report.

The 1990 census was the last to survey water sources for households, and those data are the only data currently available for demographic analyses of water source. Maine residents get their drinking water from either a self-supplied source (such as a domestic well) or from a public-water system. Public-water systems can include both communitywide systems or smaller systems designed to serve a smaller number of housing units, such as a trailer park. Self-supplied sources include drilled wells, dug wells, springs, purchased water, or a surface-water source. In Maine, the primary selfsupply is from groundwater, either a drilled or dug domestic well (U.S. Census Bureau, 1990). (Springs are also used occasionally and for this report are considered the same as domestic wells because they also have a groundwater source.) This study used 2008 population estimates (U.S. Census 
Bureau, 2008), data on the number of households per town in the 2000 census (U.S. Census Bureau, 2000), and the percentage of households using domestic wells to estimate the number of households in each town using domestic wells for their drinking water. The number of wells sampled divided by the estimated number of self-supplied households was used to give a calculated "sampling rate" for each town.

\section{Statistical Analysis of the Final Dataset}

Data summaries using the final dataset were completed for each town. For all towns, regardless of the number of samples or wells in the database, the following were tabulated: number of samples, number of wells with samples, range in concentrations, and number of wells sampled per 100 households using wells for drinking water (see above). For towns with five or more sampled wells (385 towns), the median arsenic concentration was calculated. For towns with 20 or more sampled wells (174 towns), the percentage of wells with concentrations of arsenic greater than 10, 50, 100, and $500 \mu \mathrm{g} / \mathrm{L}$ was calculated. For towns with 40 or more samples (77 towns), cumulative distribution graphs were prepared (many of which are shown in a subsequent section).

\section{Estimates of Populations and Households Served by Domestic Wells, by Town}

In 1990, public-water sources in Maine supplied 54 percent of the households. Forty-one percent of households reported using a drilled or dug well, and 5 percent reported using "other" for a water supply (U.S. Census Bureau, 1990). In areas of the State without large population centers, households generally are all self-supplied (fig. 7). Many areas of southern and coastal Maine have experienced substantial population growth since the last water-source survey in 1990. Because residential development growth since 1990 has generally tended to occur in rural areas outside the more densely populated town centers that are served by publicwater systems (The Brookings Institution, 2006), these data probably underestimate the current percentage of town populations using a self-supply (groundwater) for drinking water. The estimated number of self-supplied households (fig. 8) in southern and coastal Maine particularly is probably underestimated. All of the demographic data are provided in Appendix 1. 


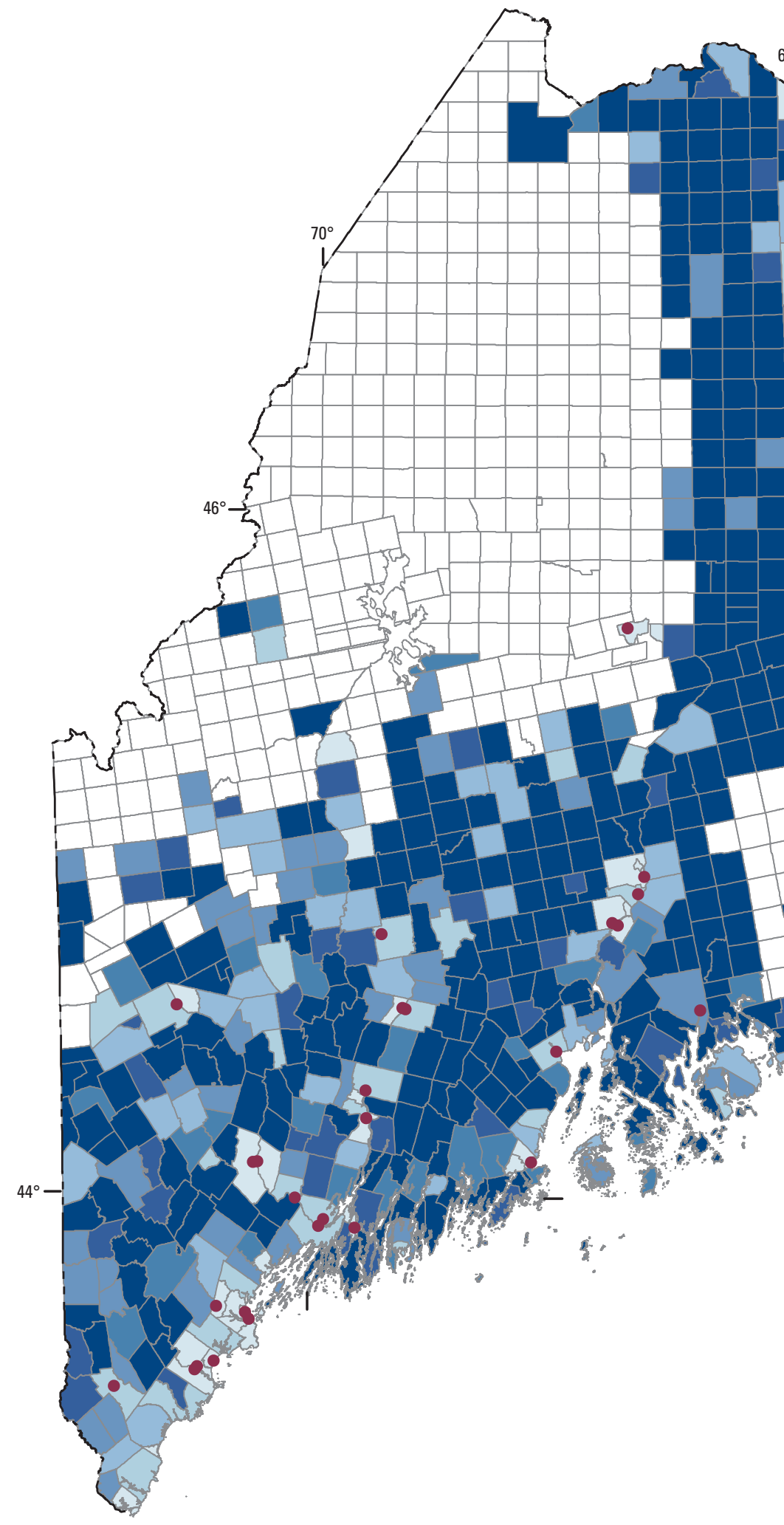

Base from USGS and Maine Office of GIS digital line graphs, 2005 Projection UTM, Zone 19N, NAD 83 Scale $1: 24,000$

\section{EXPLANATION}

Percentage of population using self supply

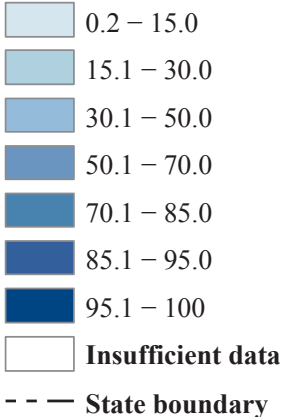

- 30 largest Maine cities/towns

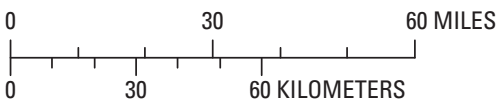

Figure 7. Percentage of town populations using a self-supply water source, generally wells, in Maine, 1990 census. Some towns have insufficient demographic data because of low population density. 


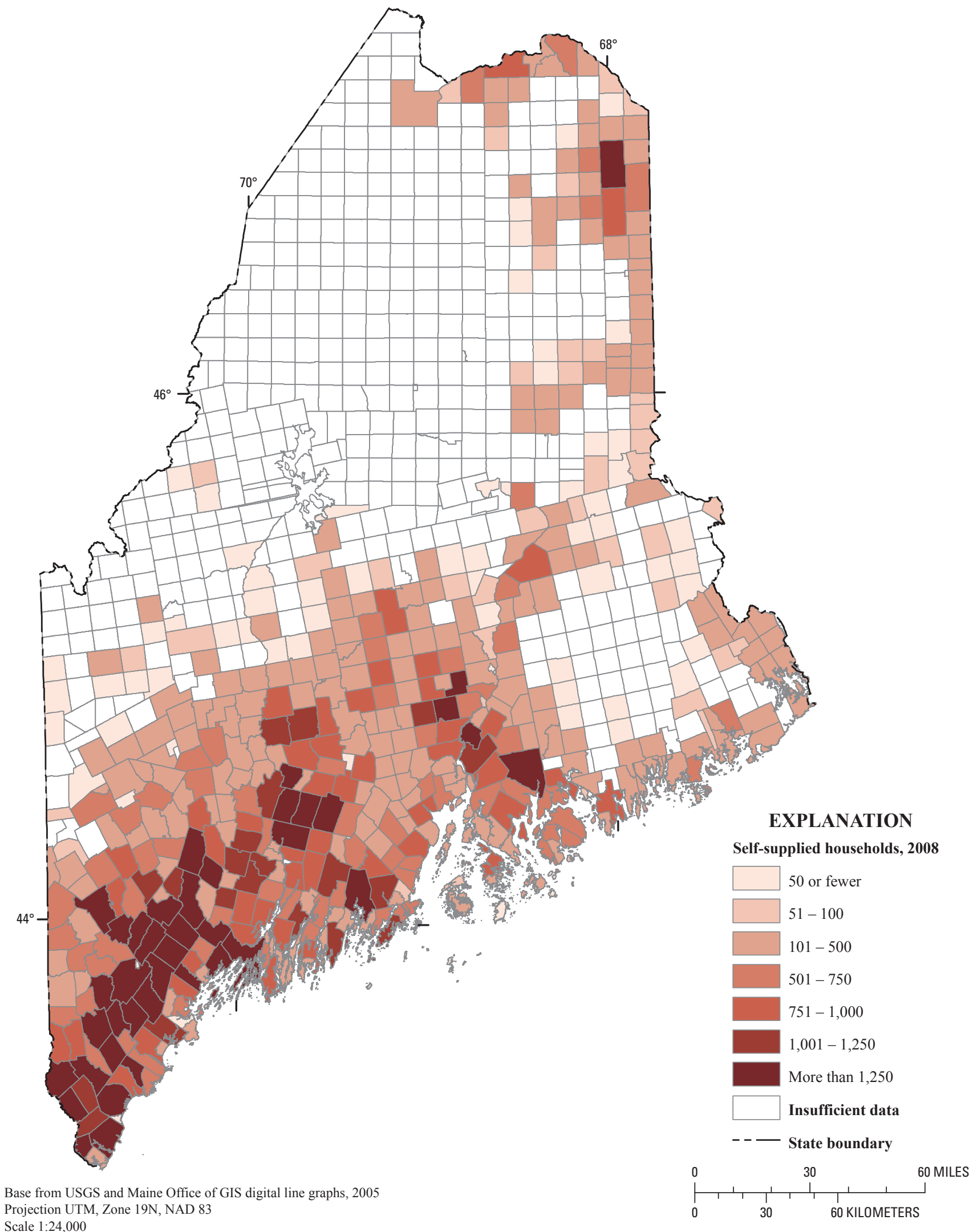

Projection UTM, Zone 19N, NAD 83

Scale $1: 24,000$

Figure 8. Estimated number of self-supplied households, by town, in Maine, 2008. Some towns have insufficient demographic data because of low population density. 
Considerations for Using Domestic Well-Water Data for Town-Wide Summaries of Arsenic Concentrations in Maine

One of the concerns about using an opportunistic dataset, such as the HETL, is the phenomenon of self-selection bias. This refers to scenarios where a domestic well owner finds that the concentration of arsenic in their domestic well is high, and alerts people living in the vicinity who also test their wells, many of which also have high concentrations of arsenic. This is thought to result in a dataset in which the locations tested are not randomly distributed, as the testing frequency would be skewed towards areas higher in arsenic. To conduct a very general test for this at the town level, data on the sampling frequency (number of wells with samples divided by the number of self-supplied households) were compared to the median and maximum arsenic concentrations for each town. Since the HETL added arsenic analyses to all their general water tests in 2002, there is a larger percentage of samples that were submitted for reasons other than specifically testing for arsenic than before 2002, which would tend to lessen the effect of self-selection bias in the dataset.

The calculated sampling rate for the organized towns in Maine for which population data were available (fig. 9) ranged from zero percent to 100 percent. Of those towns with zero percent, 20 towns had no samples in the HETL database for 2005 to $2009 ; 8$ of those had populations of greater than 40 households. All the towns with greater than 40 percent sampling rates had very low populations - fewer than 20 self-supplied households - and the calculated sampling rates in those towns are thought to be skewed by two factors: (1) seasonal property owners sending in samples from their wells and (2) underestimation of the number of self-supplied households for the 2008 population estimates. The median rate of testing in the HETL dataset for this time period is 3.8 percent, but this represents only samples sent to the HETL, not to those sent to other laboratories, so 3.8 percent is not representative of all households in Maine. The calculated sampling rate was mapped to show how this rate varied spatially across the State (fig. 10). As shown in the histogram of the sampling rates (fig. 9), most towns in the State are represented by fewer than 5 wells per hundred households (5 percent sampling rate). A few towns west of Augusta

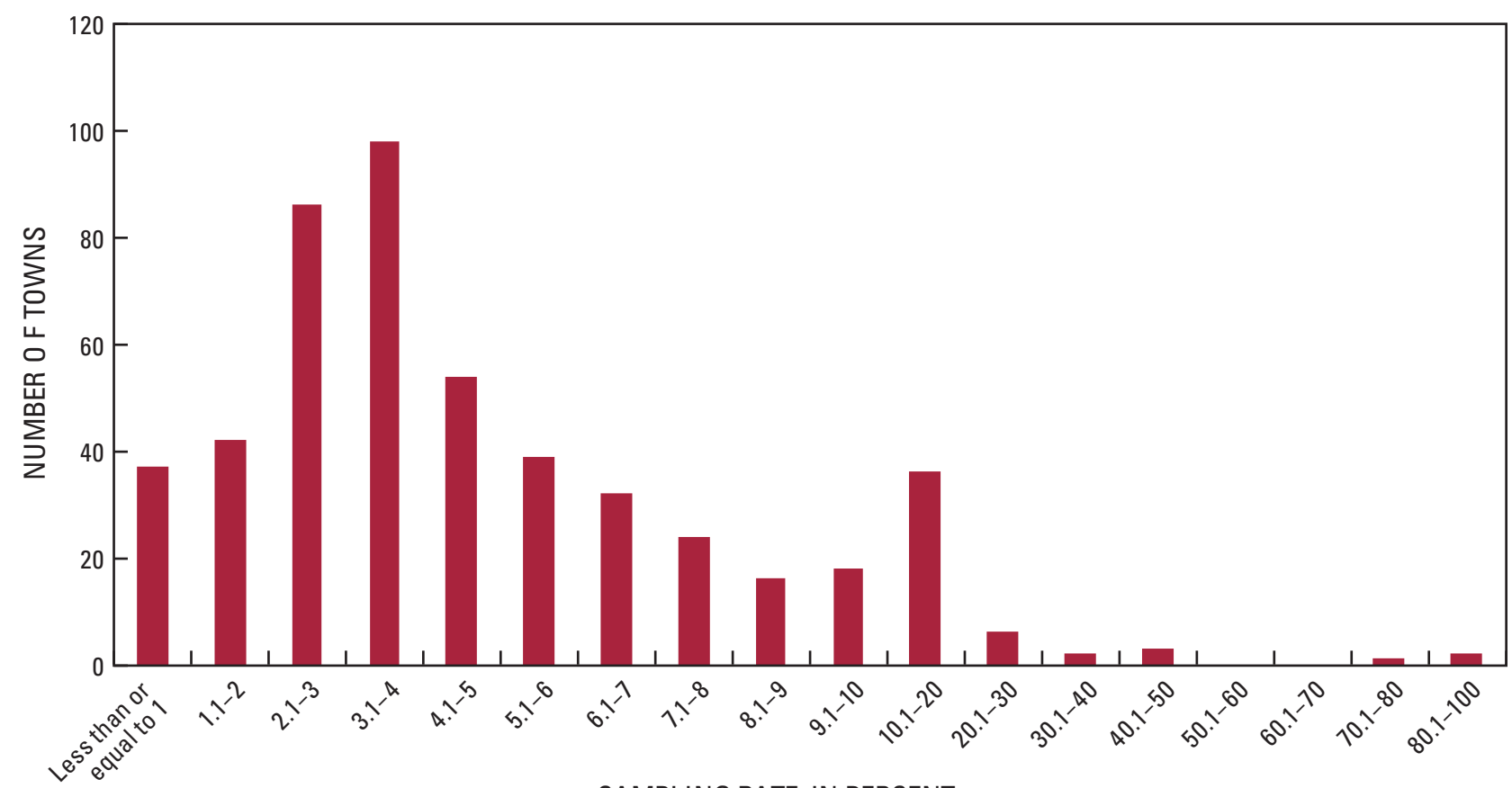

SAMPLING RATE, IN PERCENT

Figure 9. Distribution of sampling rates for arsenic in Maine towns, 2005-09. The sampling rate is the number of sampled wells in the Maine Health and Environmental Testing Laboratory dataset divided by the number of self-supplied households in each town, expressed as a percentage. 


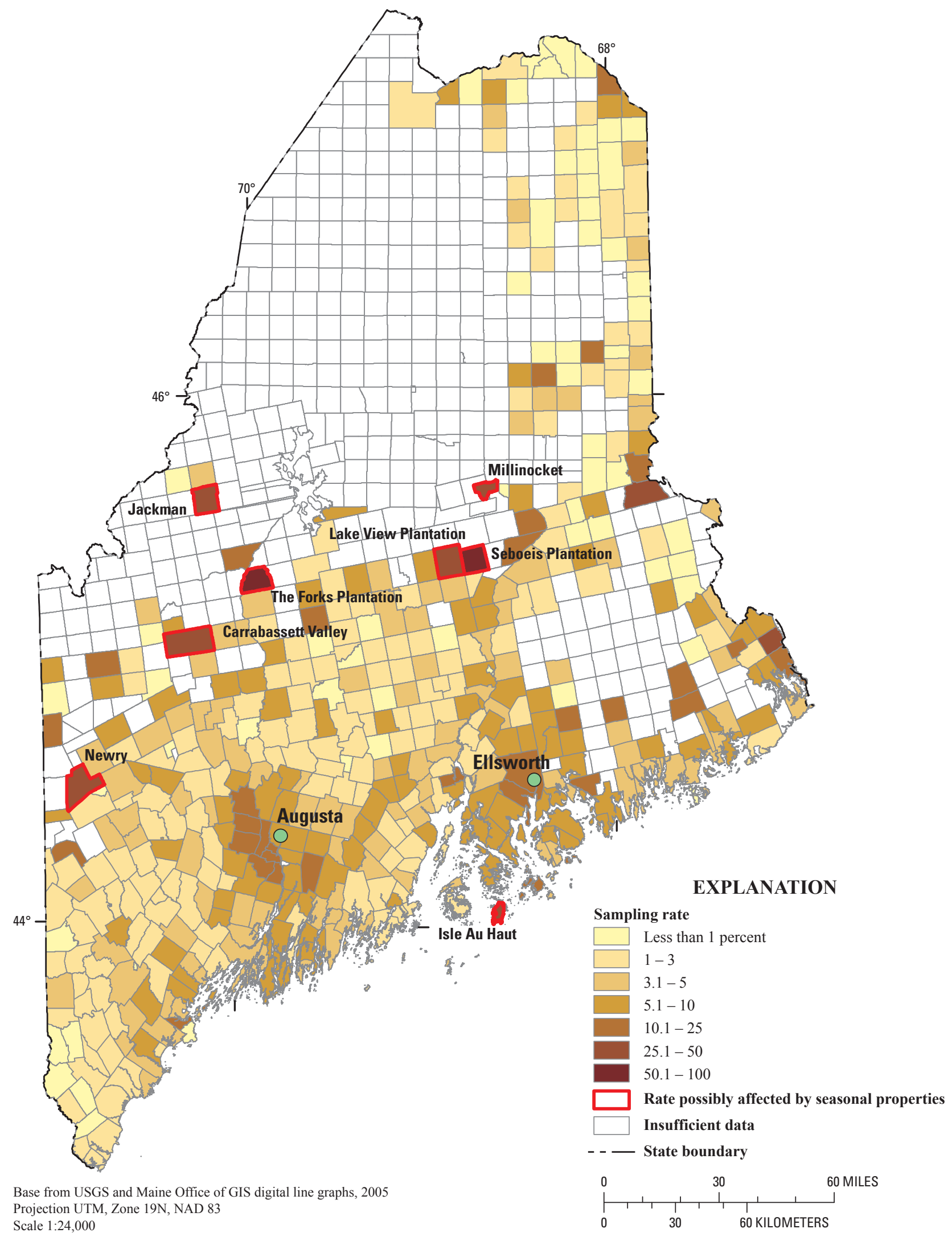

Figure 10. Sampling rate for towns, calculated as the number of sampled wells per hundred self-supplied households, in Maine, 2005-09. Some towns have insufficient demographic data because of low population density. 
have sampling rates greater than average, as do a few other towns around Ellsworth. These are areas known for having a high percentage of wells with arsenic concentrations greater than $10 \mu \mathrm{g} / \mathrm{L}$, but there do not appear to be other significant clusters of wells with higher sampling rates. On the northern fringe of the populated part of western and central Maine, there are several towns with very high sampling rates. These towns have very low populations (fewer than 40 households) and many seasonal homes. It is likely that samples submitted for seasonal properties have artificially elevated the sampling rate for households in these towns.

In order to investigate the possibility of a self-selection bias, the rate of sampling in each town was plotted against the median and maximum arsenic concentrations (fig. 11). Selfselection bias, if it exists at the town level, should be indicated by an increase in the sampling rate with increases in either the town median or maximum arsenic concentrations. It does not appear, from figure 11, that there is any overall change in the percentage of self-supplied households tested with increases in the median arsenic concentrations, but there may be an increase in the percentage of households sampled with the higher maximum concentrations.

Besides the possibility of self-selection bias in the dataset, where residents themselves alter the distribution by deciding to sample or not based on a neighbor's test results, there is the possibility of a bias in this database from efforts by State agencies, such as the ME-CDC, to encourage testing in some towns, which could affect sampling rates in towns with high concentrations of arsenic. According to staff at the ME-CDC, 124 towns were targeted during 2005-09 for increased outreach in the form of pamphlets and posters sent to town offices encouraging residents to test for arsenic (Eric Frohmberg, ME-CDC, written commun., 2010). Some of these towns also were recruited for inclusion in specific studies on arsenic distributions (Yang and others, 2009), although the samples for arsenic-specific studies were analyzed at other laboratories. The distribution of sampling rates for towns that were targeted for outreach and (or) included in specific studies and towns that were not are shown in figure $11 \mathrm{C}$. Although it is not surprising that the average maximum concentrations in the targeted towns were considerably higher than in the non-targeted towns (median and mean maximum concentrations for the non-targeted towns were 12 and $37 \mu \mathrm{g} / \mathrm{L}$, respectively, and for targeted towns, 34 and $115 \mu \mathrm{g} / \mathrm{L}$, respectively), the actual sampling rates in the targeted towns, as the percentage of self-supplied households with sampled wells in the dataset, were similar for both groups. (Median and mean sampling rates for the unsolicited towns were 6 and 4 percent, respectively, for targeted towns, 5 and 4 percent, respectively). Therefore, while the targeted towns had relatively high levels of arsenic in well water, these towns do not appear to be represented any more or less in the database than the non-targeted towns. Although the data available do not appear to indicate a high degree of self-selection bias in the medians of the town arsenic concentrations or bias from outreach by the ME-CDC, neither do the data rule out the possibility of some degree of bias in the overall distribution of arsenic when compared to a randomly designed sampling of wells in Maine, especially as it pertains to the representativeness of the maximum arsenic concentrations in towns that have relatively few samples.

Another way to look at the representativeness of samples submitted to the HETL for analysis is to consider the overall number of samples in the dataset. Towns with higher numbers of samples are believed to have data that better represents the range of conditions in those towns than towns with few samples. Towns with very few samples would need additional testing to better understand the range of arsenic concentrations in domestic wells. The range in the number of sampled wells, by town, is illustrated in figure 12. Although the authors do not propose a criterion for what constitutes enough samples, the range of arsenic found in wells in towns with 25 or more sampled wells is a better representation of actual conditions than the range in towns with fewer than 10 sampled wells.

Additional factors inherent in the dataset indicate the use of a cautious approach in the interpretation of these data. For example, the level of certainty about the physical address of each sampled well is unknown, as the actual sampled location was not requested, and only 56 percent of the sampled wells had street addresses corresponding to the town that the sample was collected in. Most of the remaining sampled wells did not have a street address. Determining which samples can be assumed to be from the same source (that is, well) involves some judgment, and the database records do not differentiate between samples collected from different wells on the same property. In the early 1990s, the HETL recorded the well type in the database, but that practice was discontinued sometime after the study by Marvinney and others (1994) and before 2005.

As already described, filtration or water treatment is another issue that cannot be definitively determined for most of the samples in this dataset. For reasons described above, the filtration information recorded in the database is incomplete and cannot be relied on for statistical segregation. Many residents may not provide the information because it is not necessary for their understanding of their own water sample. (They likely already know whether or not it is filtered.) Other residents may not know exactly what filtration is being applied to their water, particularly if the house was purchased with a filtration system already installed. Furthermore, the form does not state the importance of the information, and the HETL does not have a separate field for the information in the database. (Filtration information is included in the Sample Description field when data are entered.) Also, many filters that are commonly used, such as sand filters (which are quite common), do little to affect arsenic concentrations, although iron and manganese filters may remove some arsenic. 

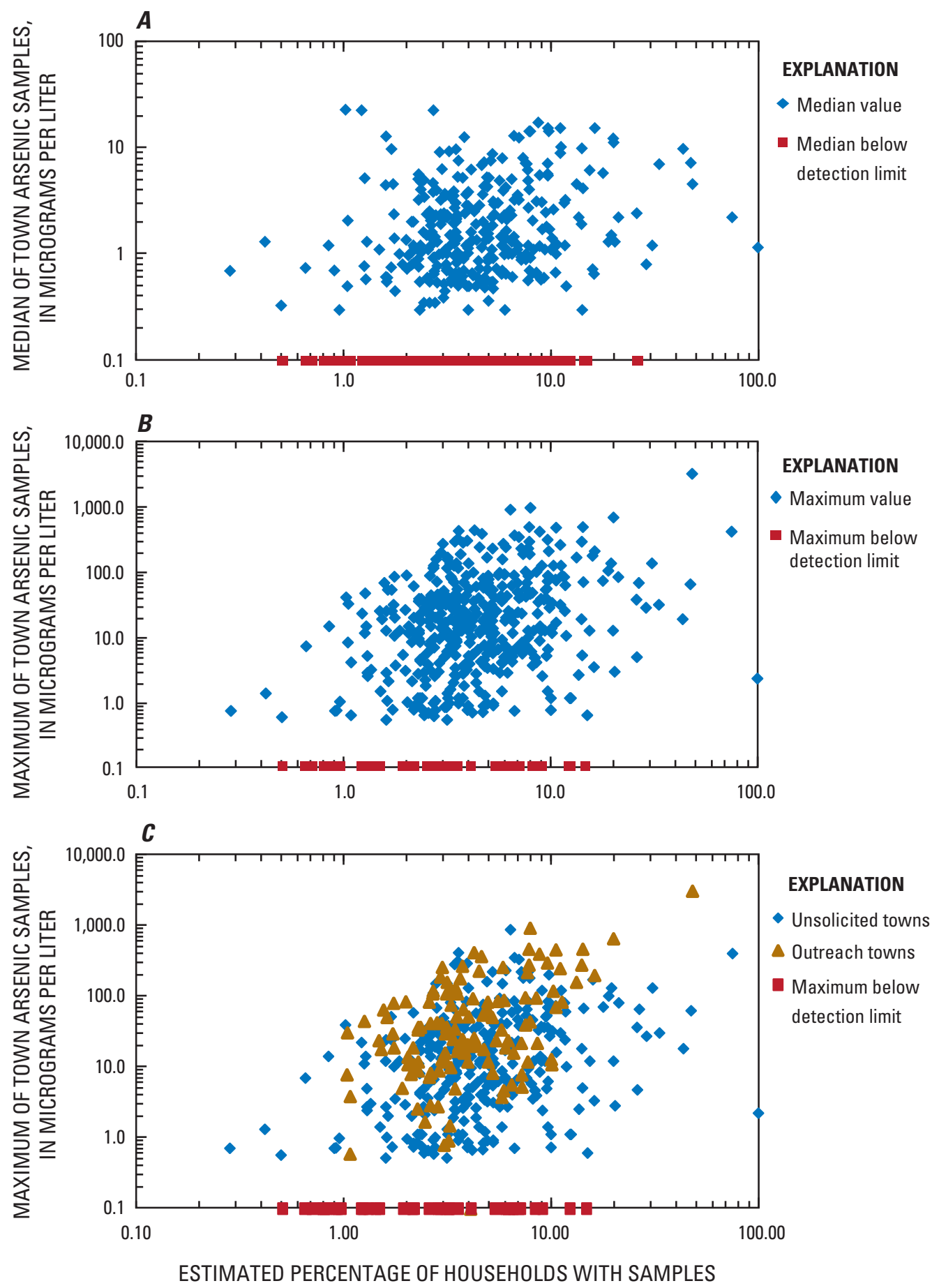

Figure 11. Estimated percentage of households with sampled wells in each town in relation to $(A)$ the median of all samples in each town, $(B)$ the maximum of all samples in each town, and $(C)$, the maximum of samples in each town broken down by whether the towns were targeted for outreach by the Maine Centers for Disease Control and Prevention or whether they were unsolicited. All towns with the median, for graph $(A)$, or the maximum, for graphs $(B)$ and $(C)$, below the detection limit of 0.5 micrograms per liter are graphed at 0.1 micrograms per liter. 


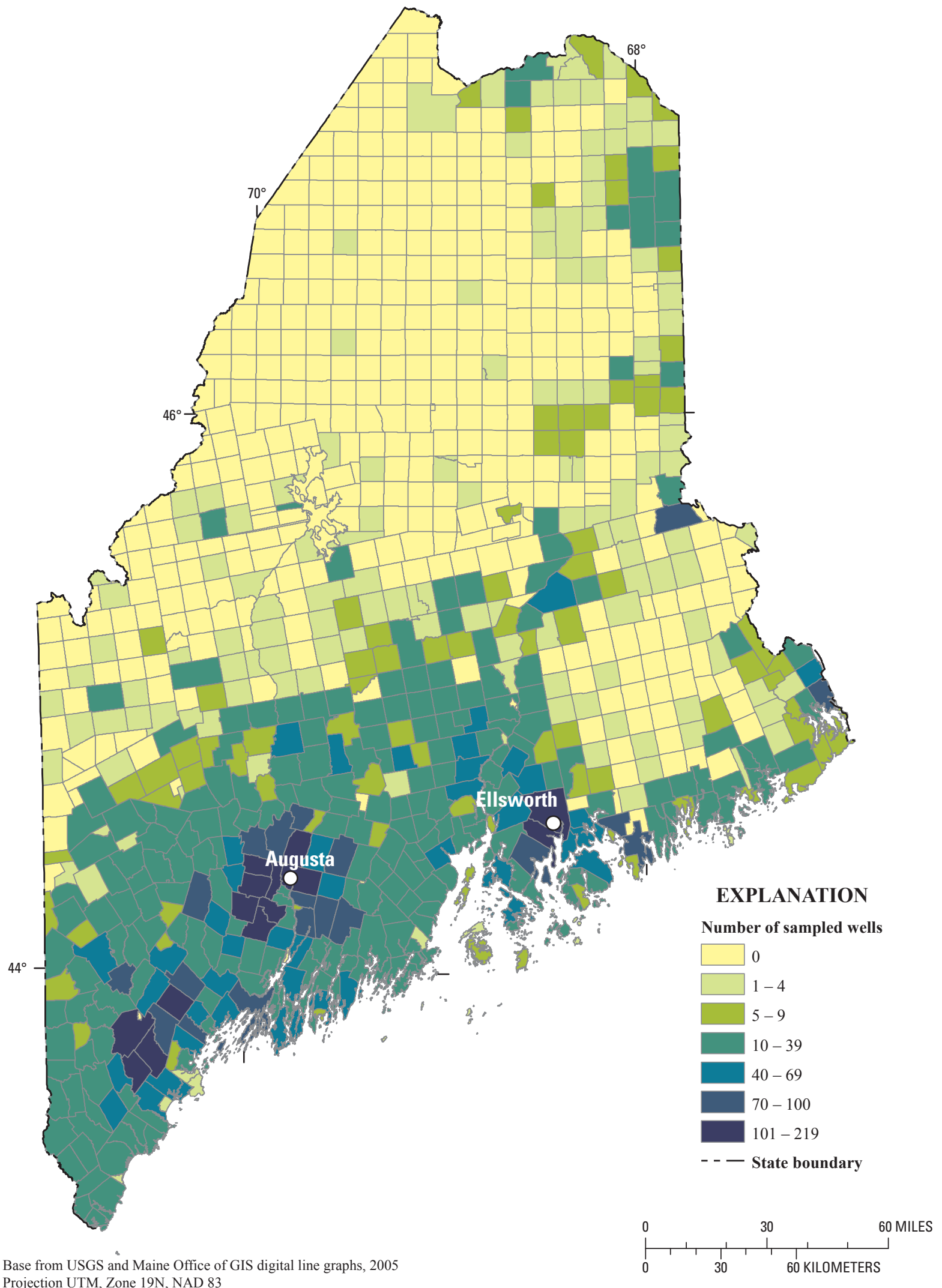

Projection UTM, Zone 19N, NAD 83

Scale 1:24,000

Figure 12. Total numbers of sampled wells in the Maine Health and Environmental Testing Laboratory database, 2005-09, and some known areas of elevated arsenic levels. 


\section{Arsenic Concentrations in Domestic Well Water in Maine}

Overall, approximately 18,000 records were retrieved from the HETL database. Of these, 14,282 had unique laboratory identification numbers. After screening the data, 13,843 samples collected from 11,111 wells were used for analysis. Samples that had associated street addresses represent 56 percent of all the samples. Some information on filtration or water treatment was included in 52 percent of the samples. Just under 16 percent of the sampled wells had more than one sample recorded in the dataset.

A total of 531 of Maine's 908 minor civil divisions (488 organized municipalities and 420 unorganized territories-all referred to as "towns" in this report) are represented in the dataset; the total number of wells with samples in the database, by town, is mapped in figure 12. Many of the towns with large sample densities, such as towns in Cumberland and Kennebec Counties and the area surrounding the town of Ellsworth, are areas that have been previously identified as having high concentrations of arsenic (>50 $\mu \mathrm{g} / \mathrm{L})$. However, areas with very low population densities have few samples in the State database.

Overall, 18.4 percent of the wells with samples in the HETL database had arsenic concentrations greater than $10 \mu \mathrm{g} / \mathrm{L}$, and 4 percent of these wells had arsenic concentrations greater than $50 \mu \mathrm{g} / \mathrm{L}$. Given that there were approximately 241,000 self-supplied households in Maine in 2008, a generic extrapolation to the self-supplied population in Maine would indicate that more than 44,000 households in the State could possibly have well water with concentrations of arsenic that exceed the $10 \mu \mathrm{g} / \mathrm{L}$ USEPA standard. However, this calculation would assume that the HETL dataset is an unbiased sample of wells across the state, which it probably is not, especially since the number of wells sampled in each town varies so widely. An earlier study that used a random sampling design with almost 1,000 wells across the State found that 10 percent of sampled wells had arsenic levels of $10 \mu \mathrm{g} / \mathrm{L}$ or greater (Loiselle and others, 2001). Using the same number of self-supplied households, that study would indicate that over 24,000 households in Maine could have well water exceeding the USEPA standard. Given the spatial variability of the self-supplied rural population in Maine and the spatial variability of areas high in arsenic in groundwater, it would be difficult to design a study that determined definitively the number of wells in Maine with arsenic above the USEPA standard. In the end, these data do not represent a random sample of wells from each town; rather, they provide the best indicator of high concentrations, by town, of any available datasets and are a better indicator of arsenic hot-spots than data from randomly designed studies.

\section{Statistical Distributions of Arsenic Concentrations, by Town}

The number of samples, number of wells sampled, minimum and maximum concentrations, and median concentrations of arsenic are reported for all 531 towns in Appendix 2. Of the towns with five or more sampled wells recorded in the dataset, the 30 towns with the highest maximum arsenic concentrations are listed in table 3 , and the 30 towns with the highest median arsenic concentrations are listed in table 4 . The 30 highest maximum arsenic concentrations in wells in this dataset range from 200 to $3,100 \mu \mathrm{g} / \mathrm{L}$, and the 30 highest median arsenic concentrations range from 5.5 to $22 \mu \mathrm{g} / \mathrm{L}$. Many of the towns in these two lists could be considered well characterized because they are represented by samples from more than 40 wells. However, in both lists, there are several towns that have samples from fewer than 10 wells, such as the towns of Seboies Plantation and Atkinson, which have maximum concentrations of 400 and $290 \mu \mathrm{g} / \mathrm{L}$, respectively, (table 3) and the towns of Passadumkeag, Anson, and Monson (see fig. 2), which have median concentrations from 9.5 to $12.4 \mu \mathrm{g} / \mathrm{L}$ (table 4). These towns are not heavily populated, but the relatively high concentrations in these towns may deserve further investigation.

Maps showing the spatial distribution of the maximum (fig. 13) and median (fig. 14) arsenic concentrations for the same towns show that the distribution of high arsenic concentrations ( $>50 \mu \mathrm{g} / \mathrm{L}$ ) in wells follows some geographic patterns. There are obvious clusters of towns with high arsenic occurrence (such as southern coastal areas, the Kennebec County area, and the central coastal part of Maine), as well as definite areas of the State with low arsenic concentrations, such as the northernmost towns sampled and the western and west-central part of Maine. The clusters in the areas around Augusta and Ellsworth, and the cluster in southern coastal Maine, are all well characterized because the towns in these areas have many samples in the dataset (see fig. 11) and have been well documented in past studies (Loiselle and others, 2001; Ayotte and others, 2003; Marvinney and others, 1994; Yang and others, 2009). Other isolated towns with relatively high maximum concentrations ( $>100 \mu \mathrm{g} / \mathrm{L}$ ), however, are in areas of the State with relatively few samples (and low populations). These towns and the towns around them may be targeted for further investigation.

The percentage of wells with arsenic concentrations exceeding $10,50,100$, and $500 \mu \mathrm{g} / \mathrm{L}$ in the 174 towns with 20 or more sampled wells are listed in Appendix 3, and the towns with the 30 highest percentages of wells with concentrations greater than $10 \mu \mathrm{g} / \mathrm{L}$ are listed in table 5 . Eleven towns had over 40 percent of the sampled wells exceeding $10 \mu \mathrm{g} / \mathrm{L}$. Because these towns each had from 60 to 218 samples, these towns could be considered well characterized. Extrapolating to the total self-supplied 
populations in these 11 towns, more than 17,500 people could be using wells with water that exceeds the USEPA limit for arsenic, if left untreated. As expected, many fewer towns had wells with concentrations exceeding the 50,100, and $500 \mu \mathrm{g} / \mathrm{L}$ categories. Only 19 towns had more than 10 percent of wells exceeding $50 \mu \mathrm{g} / \mathrm{L}$, and 44 towns had 1 or more percent exceeding $100 \mu \mathrm{g} / \mathrm{L}$. In Surry, Hancock County (one of the 19 towns), 23 percent of the 120 wells sampled had concentrations exceeding $100 \mu \mathrm{g} / \mathrm{L}$, which is a much higher frequency than for any other town. In only four towns (Danforth in Washington County, Surry and Blue Hill in Hancock County, and Woolwich in Sagadahoc County) was there 1 percent or more of the wells with concentrations greater than $500 \mu \mathrm{g} / \mathrm{L}$ during 2005-09. Most of these towns have relatively high numbers of wells in the dataset. Maps showing the percentage of wells with concentrations of arsenic exceeding 10, 50, 100, and $500 \mu \mathrm{g} / \mathrm{L}$ (figs. 15-18) portray the same distinct geographic patterns of high arsenic concentrations across the State as presented earlier, although these maps show only towns with 20 or more samples in the dataset. Earlier studies identified other clusters of very high arsenic levels in or near the towns of Northport (Lipfert and others, 2006), the Buxton/Hollis area (Marvinney and others, 1994), and Waldoboro (Sidle, 2003), but the associated samples were collected before 2005 and did not factor into this analysis.

Although the data in this study are limited in their usefulness by the fact that they are non-random data, and of low quality in terms of location and ancillary data, these data are unique in that they point specifically to towns with very high arsenic concentrations in bedrock groundwater. These high concentrations are rarely captured by randomly designed studies, so the strength of these analyses lies in the identification of towns with wells having high arsenic concentrations.

Ayotte and others (2006) published a map showing the probability of arsenic concentrations exceeding $5 \mu \mathrm{g} / \mathrm{L}$ in groundwater wells in bedrock in the southern half of Maine. This probability map is based on a logistic-regression model that takes into account bedrock geologic type, stream sediment arsenic, hydrologic variables, land use, and two geochemical processes (Ayotte and others, 2006). While this probability map is based on the probability of arsenic exceeding $5 \mu \mathrm{g} / \mathrm{L}$, the spatial patterns can be compared to the spatial patterns observed in the map showing the percentage of wells found to have arsenic concentrations exceeding $10 \mu \mathrm{g} / \mathrm{L}$ from the HETL dataset (fig. 15). The areas of highest probabilities of having a well with arsenic greater than $5 \mu \mathrm{g} / \mathrm{L}$ in Maine correspond somewhat to the areas found to have wells exceeding $10 \mu \mathrm{g} / \mathrm{L}$ in the HETL dataset; particularly, the Ellsworth-Surry-Blue Hill area is identified in both maps. Both studies show few wells (or a predicted small probability of finding wells) with elevated arsenic in southern Oxford County and western Cumberland County. However, the area found to have high arsenic west of Augusta in Kennebec County in the HETL dataset (figs. 13-15) is not predicted to have as high a probability of elevated arsenic in the probability map as areas in southeast Kennebec County and Lincoln County, which were found in the HETL dataset to have quite low percentages of wells exceeding $10 \mu \mathrm{g} / \mathrm{L}$ (fig. 15). Predictions of relatively high probabilities of wells with elevated arsenic in eastern Washington County are not borne out by the HETL data, and the cluster in the Rangeley area was not predicted by the logistic-regression model. However, the HETL database was not designed to specifically test the logistic regression model, so it is difficult to draw specific conclusions about the accuracy of the model from these data. 
Table 3. Towns with the 30 highest maximum arsenic concentrations, of the towns with five or more sampled wells in the Maine Health and Environmental Testing Laboratory database, 2005-09.

[ $\mu \mathrm{g} / \mathrm{L}$, micrograms per liter; <, less than; Plt, plantation]

\begin{tabular}{|c|c|c|c|c|c|c|}
\hline \multirow[b]{2}{*}{ County } & \multirow[b]{2}{*}{ Town } & \multirow[b]{2}{*}{$\begin{array}{c}\text { Total number of } \\
\text { samples }\end{array}$} & \multirow[b]{2}{*}{$\begin{array}{l}\text { Number of wells } \\
\text { with samples }\end{array}$} & \multicolumn{3}{|c|}{ Town arsenic concentrations } \\
\hline & & & & $\underset{(\mu \mathrm{g} / \mathrm{L})}{\text { Minimum }}$ & $\begin{array}{c}\text { Maximum } \\
(\mu \mathrm{g} / \mathrm{L})\end{array}$ & $\begin{array}{c}\text { Median } \\
(\mu \mathrm{g} / \mathrm{L})\end{array}$ \\
\hline Washington & Danforth & 123 & 71 & $<0.5$ & 3,100 & 4.5 \\
\hline Hancock & Blue Hill & 107 & 75 & $<.5$ & 930 & 14.0 \\
\hline Sagadahoc & Woolwich & 71 & 63 & $<.5$ & 870 & $<.5$ \\
\hline Hancock & Surry & 141 & 120 & $<.5$ & 660 & 11.0 \\
\hline Hancock & Ellsworth & 272 & 219 & $<.5$ & 470 & 4.1 \\
\hline Hancock & Sedgwick & 41 & 33 & $<.5$ & 470 & 4.0 \\
\hline Franklin & Rangeley & 49 & 37 & $<.5$ & 460 & 1.0 \\
\hline Cumberland & Standish & 149 & 120 & $<.5$ & 420 & 2.5 \\
\hline York & Biddeford & 21 & 18 & $<.5$ & 410 & 7.5 \\
\hline Kennebec & Litchfield & 156 & 110 & $<.5$ & 400 & 5.5 \\
\hline Penobscot & Seboeis Plt & 17 & 9 & .7 & 400 & 2.2 \\
\hline Kennebec & Vassalboro & 75 & 60 & $<.5$ & 370 & 6.8 \\
\hline York & Saco & 84 & 63 & $<.5$ & 350 & 3.2 \\
\hline Oxford & Buckfield & 47 & 36 & $<.5$ & 330 & 3.2 \\
\hline Knox & Rockport & 35 & 22 & $<.5$ & 310 & 5.3 \\
\hline Kennebec & Monmouth & 127 & 111 & $<.5$ & 300 & 7.0 \\
\hline Piscataquis & Atkinson & 5 & 5 & $<.5$ & 290 & .5 \\
\hline Cumberland & Gorham & 287 & 218 & $<.5$ & 280 & 14.0 \\
\hline Kennebec & Readfield & 179 & 129 & $<.5$ & 280 & 9.7 \\
\hline Waldo & Lincolnville & 40 & 30 & $<.5$ & 280 & 2.7 \\
\hline York & Buxton & 144 & 114 & $<.5$ & 270 & 5.2 \\
\hline Cumberland & Gray & 141 & 111 & $<.5$ & 260 & 3.9 \\
\hline York & Hollis & 65 & 49 & $<.5$ & 260 & 2.1 \\
\hline Kennebec & Winthrop & 173 & 130 & $<.5$ & 250 & 8.8 \\
\hline Hancock & Penobscot & 43 & 31 & $<.5$ & 230 & 4.2 \\
\hline Knox & Union & 50 & 36 & $<.5$ & 230 & 2.9 \\
\hline Cumberland & Scarborough & 84 & 61 & $<.5$ & 220 & 8.6 \\
\hline Hancock & Franklin & 36 & 31 & $<.5$ & 220 & .9 \\
\hline Kennebec & Belgrade & 126 & 95 & $<.5$ & 220 & 6.1 \\
\hline Kennebec & Chelsea & 84 & 75 & $<.5$ & 220 & 1.2 \\
\hline
\end{tabular}


Table 4. Towns with the 30 highest median arsenic concentrations, of the towns with five or more sampled wells in the Maine Health and Environmental Testing Laboratory database, 2005-09.

[ $\mu \mathrm{g} / \mathrm{L}$, micrograms per liter; $<$, less than; Plt, plantation]

\begin{tabular}{|c|c|c|c|c|c|c|}
\hline \multirow[b]{2}{*}{ County } & \multirow[b]{2}{*}{ Town } & \multirow[b]{2}{*}{$\begin{array}{l}\text { Total number of } \\
\text { samples }\end{array}$} & \multirow[b]{2}{*}{$\begin{array}{l}\text { Number of wells } \\
\text { with samples }\end{array}$} & \multicolumn{3}{|c|}{ Town arsenic concentrations } \\
\hline & & & & $\underset{(\mu \mathrm{g} / \mathrm{L})}{\text { Minimum }}$ & $\begin{array}{c}\text { Maximum } \\
(\mu \mathrm{g} / \mathrm{L})\end{array}$ & $\begin{array}{c}\text { Median } \\
(\mu \mathrm{g} / \mathrm{L})\end{array}$ \\
\hline Knox & Camden & 31 & 18 & $<0.5$ & 120 & 22.0 \\
\hline Kennebec & Manchester & 175 & 111 & $<.5$ & 200 & 15.0 \\
\hline Cumberland & Gorham & 287 & 218 & $<.5$ & 280 & 14.0 \\
\hline Hancock & Blue Hill & 107 & 75 & $<.5$ & 930 & 14.0 \\
\hline Washington & Columbia & 22 & 17 & $<.5$ & 200 & 14.0 \\
\hline Hancock & Otis & 18 & 14 & $<.5$ & 85.0 & 12.7 \\
\hline Penobscot & Passadumkeag & 9 & 6 & $<.5$ & 35.0 & 12.4 \\
\hline Hancock & Surry & 141 & 120 & $<.5$ & 660 & 11.0 \\
\hline Kennebec & Hallowell & 18 & 15 & .7 & 120 & 10.0 \\
\hline Kennebec & Readfield & 179 & 129 & $<.5$ & 280 & 9.7 \\
\hline Piscataquis & Lake View Plt & 11 & 10 & 3.7 & 18.0 & 9.6 \\
\hline Somerset & Anson & 8 & 6 & $<.5$ & 24.0 & 9.6 \\
\hline Piscataquis & Monson & 12 & 7 & 2.2 & 33.0 & 9.5 \\
\hline York & Newfield & 18 & 16 & $<.5$ & 28.0 & 9.0 \\
\hline Kennebec & Winthrop & 173 & 130 & $<.5$ & 250 & 8.8 \\
\hline Cumberland & Scarborough & 84 & 61 & $<.5$ & 220 & 8.6 \\
\hline Waldo & Northport & 43 & 35 & $<.5$ & 180 & 7.9 \\
\hline Washington & Baring Plt & 15 & 6 & 2.3 & 150 & 7.9 \\
\hline York & Biddeford & 21 & 18 & $<.5$ & 410 & 7.5 \\
\hline Penobscot & Millinocket & 10 & 9 & 1.1 & 62.0 & 7.1 \\
\hline Hancock & Trenton & 53 & 44 & $<.5$ & 97.0 & 7.1 \\
\hline Kennebec & Monmouth & 127 & 111 & $<.5$ & 300 & 7.0 \\
\hline Hancock & Mariaville & 20 & 14 & $<.5$ & 65.0 & 7.0 \\
\hline Knox & Isle Au Haut & 10 & 7 & $<.5$ & 30.0 & 6.9 \\
\hline Kennebec & Vassalboro & 75 & 60 & $<.5$ & 370 & 6.8 \\
\hline York & Eliot & 55 & 39 & $<.5$ & 42.0 & 6.2 \\
\hline Kennebec & Belgrade & 126 & 95 & $<.5$ & 220 & 6.1 \\
\hline Aroostook & Weston & 18 & 15 & $<.5$ & 70.0 & 5.7 \\
\hline Piscataquis & Brownville & 22 & 19 & $<.5$ & 69.0 & 5.6 \\
\hline Kennebec & Litchfield & 156 & 110 & $<.5$ & 400 & 5.5 \\
\hline
\end{tabular}




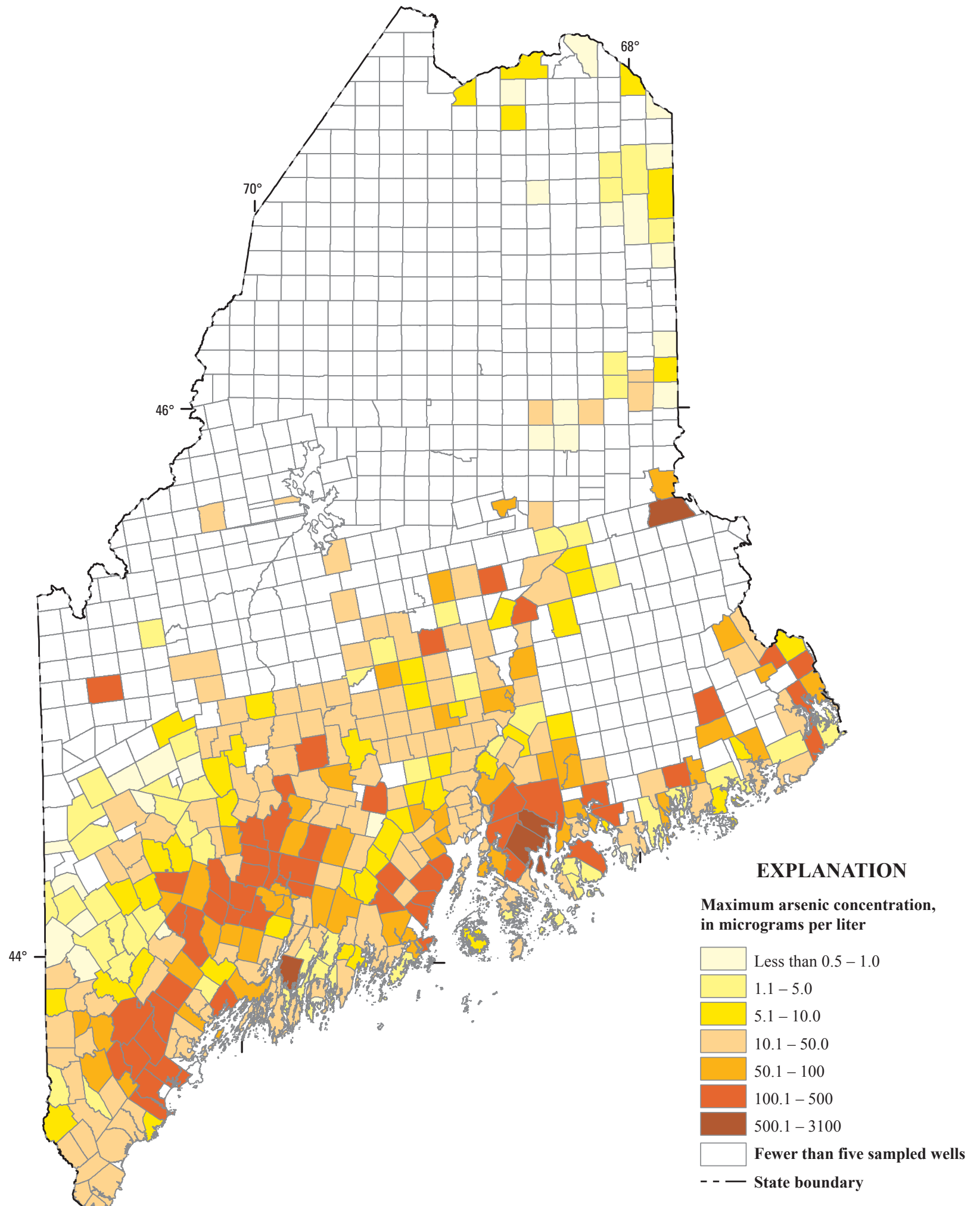

Base from USGS and Maine Office of GIS digital line graphs, 2005 Projection UTM, Zone 19N, NAD 83 Scale 1:24,000

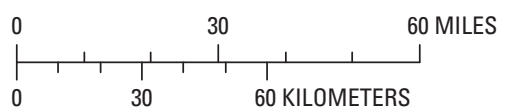

Figure 13. Maximum arsenic concentrations for towns with five or more sampled wells in Maine, 2005-09. 


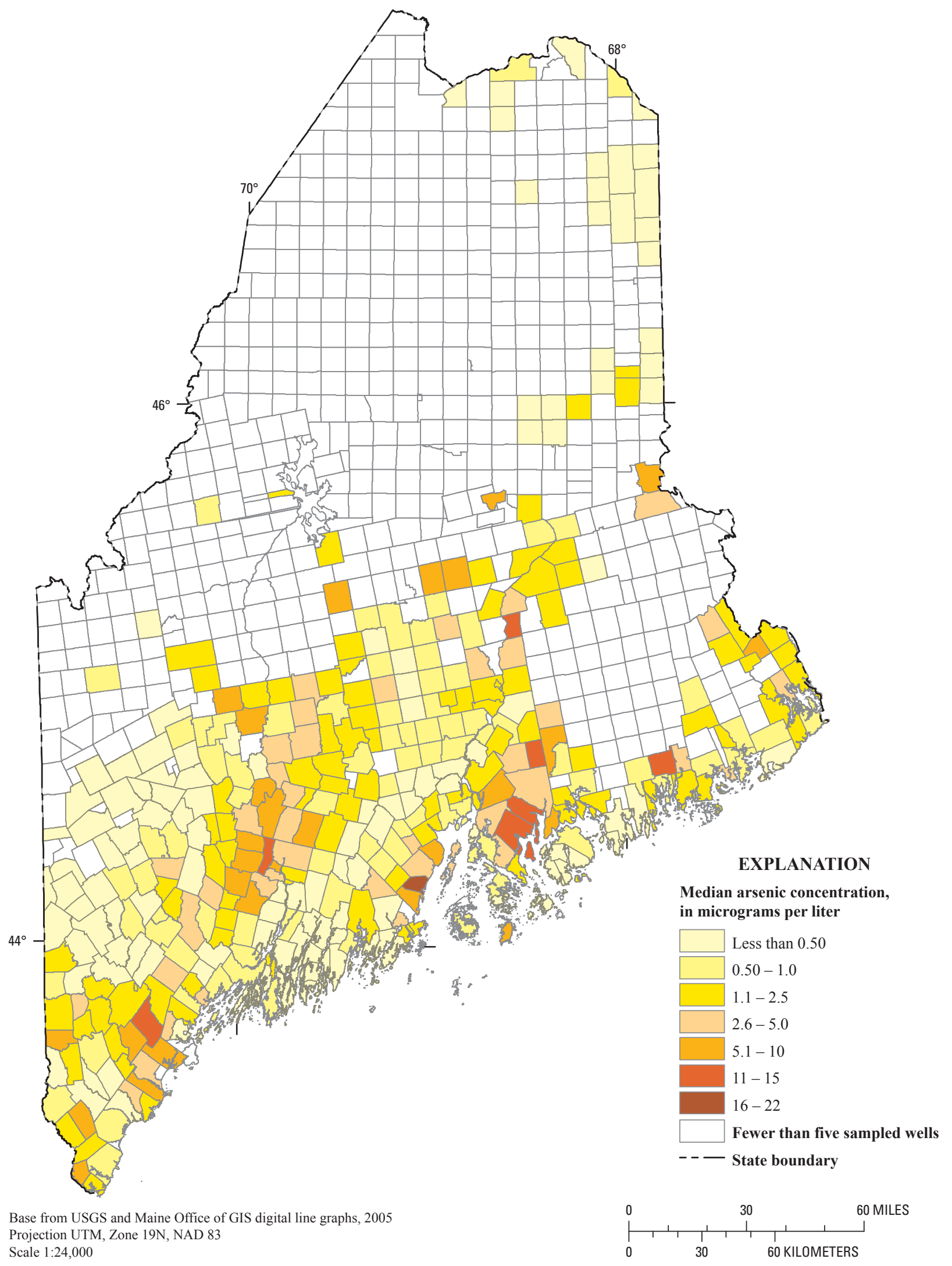

Figure 14. Median arsenic concentrations for towns with five or more sampled wells in Maine, 2005-09. 
Table 5. Towns with the 30 highest percentages of wells with arsenic concentrations exceeding 10 micrograms per liter, of the towns with 20 sampled wells in the Maine Health and Environmental Testing Laboratory, 2005-09, and percentages of wells in those towns with arsenic concentrations exceeding 50, 100, and 500 migrograms per liter.

[ $\mu \mathrm{g} / \mathrm{L}$, micrograms per liter; As, arsenic]

\begin{tabular}{|c|c|c|c|c|c|c|}
\hline County & Town & $\begin{array}{c}\text { Number of } \\
\text { wells sampled }\end{array}$ & $\begin{array}{c}\text { Percentage of } \\
\text { wells exceeding } \\
10 \mu \mathrm{g} / \mathrm{L} \mathrm{As}\end{array}$ & $\begin{array}{l}\text { Percentage of } \\
\text { wells exceeding } \\
50 \mu \mathrm{g} / \mathrm{L} \mathrm{As}\end{array}$ & $\begin{array}{l}\text { Percentage of } \\
\text { wells exceeding } \\
100 \mu \mathrm{g} / \mathrm{L} \mathrm{As}\end{array}$ & $\begin{array}{c}\text { Percentage of } \\
\text { wells exceeding } \\
500 \mu \mathrm{g} / \mathrm{L} \mathrm{As}\end{array}$ \\
\hline Kennebec & Manchester & 111 & 62 & 19 & 3 & 0 \\
\hline Cumberland & Gorham & 218 & 57 & 22 & 8 & 0 \\
\hline Hancock & Blue Hill & 75 & 57 & 15 & 11 & 3 \\
\hline Hancock & Surry & 120 & 51 & 33 & 23 & 2 \\
\hline Kennebec & Readfield & 129 & 49 & 12 & 3 & 0 \\
\hline Cumberland & Scarborough & 61 & 48 & 10 & 3 & 0 \\
\hline Kennebec & Winthrop & 130 & 46 & 12 & 2 & 0 \\
\hline Kennebec & Monmouth & 111 & 45 & 14 & 6 & 0 \\
\hline Washington & Danforth & 71 & 42 & 20 & 11 & 8 \\
\hline Kennebec & Litchfield & 110 & 42 & 15 & 5 & 0 \\
\hline York & Buxton & 114 & 41 & 11 & 5 & 0 \\
\hline Hancock & Trenton & 44 & 39 & 5 & 0 & 0 \\
\hline York & Eliot & 39 & 38 & 0 & 0 & 0 \\
\hline Androscoggin & Greene & 43 & 37 & 9 & 2 & 0 \\
\hline Waldo & Northport & 35 & 37 & 14 & 6 & 0 \\
\hline Hancock & Ellsworth & 219 & 37 & 11 & 5 & 0 \\
\hline Knox & Rockport & 22 & 36 & 18 & 9 & 0 \\
\hline Franklin & Rangeley & 37 & 35 & 8 & 5 & 0 \\
\hline Hancock & Orland & 40 & 35 & 3 & 3 & 0 \\
\hline Kennebec & Vassalboro & 60 & 35 & 2 & 2 & 0 \\
\hline Kennebec & Mount Vernon & 86 & 35 & 5 & 1 & 0 \\
\hline York & Hollis & 49 & 35 & 16 & 6 & 0 \\
\hline Androscoggin & Minot & 32 & 34 & 3 & 3 & 0 \\
\hline Hancock & Sedgwick & 33 & 33 & 12 & 9 & 0 \\
\hline Kennebec & Albion & 24 & 33 & 0 & 0 & 0 \\
\hline Knox & Union & 36 & 33 & 8 & 3 & 0 \\
\hline Somerset & Fairfield & 24 & 33 & 0 & 0 & 0 \\
\hline York & Dayton & 27 & 33 & 11 & 0 & 0 \\
\hline Kennebec & Belgrade & 95 & 33 & 2 & 1 & 0 \\
\hline Androscoggin & Auburn & 37 & 32 & 3 & 3 & 0 \\
\hline Somerset & Skowhegan & 34 & 32 & 12 & 6 & 0 \\
\hline
\end{tabular}




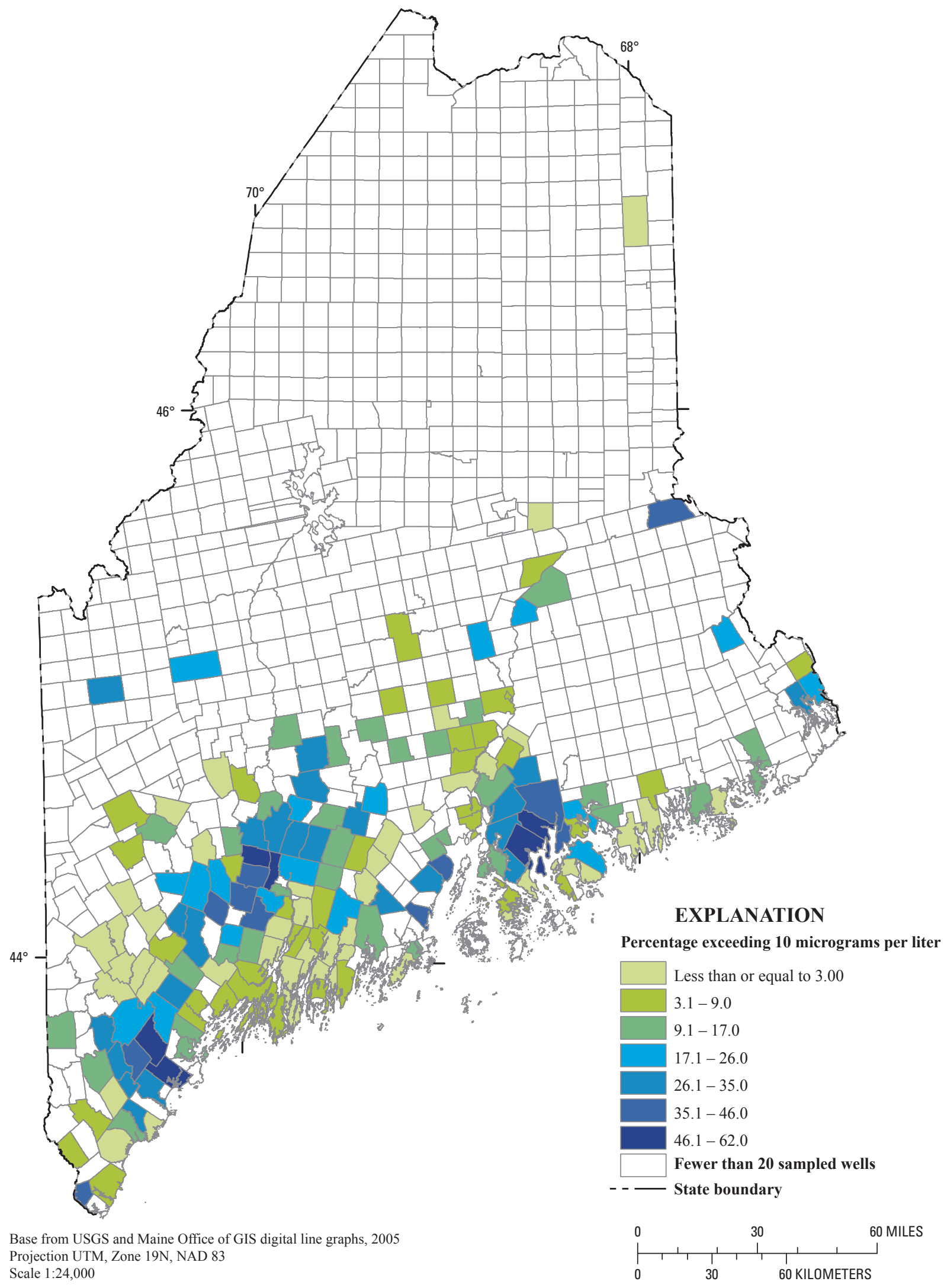

Figure 15. Percentage of wells in each town with arsenic concentrations greater than 10 micrograms per liter in Maine, 2005-09. Towns shown have 20 or more sampled wells. 


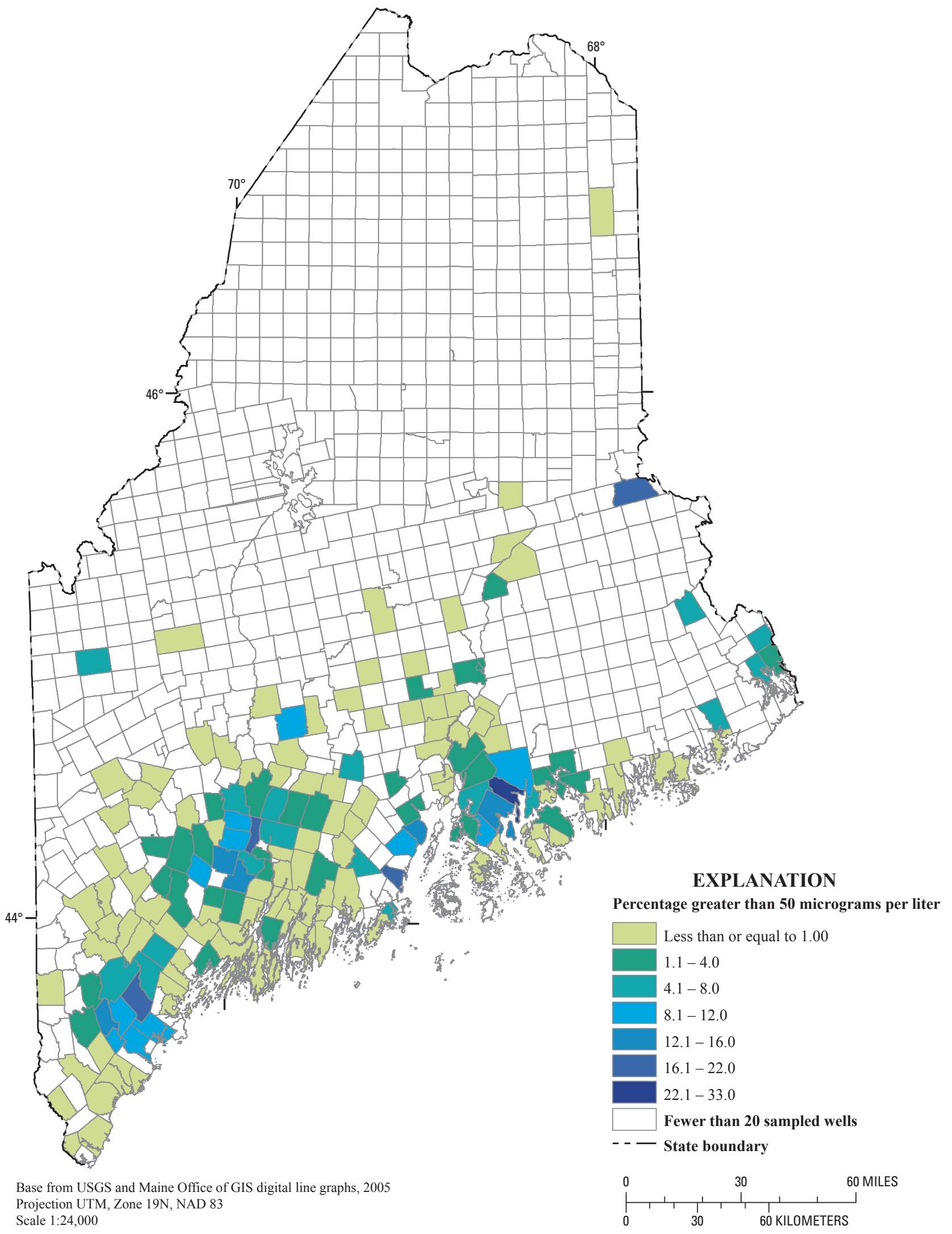

Figure 16. Percentage of wells in each town with arsenic concentrations greater than 50 micrograms per liter, in Maine, 2005-09. Towns shown have 20 or more sampled wells. 


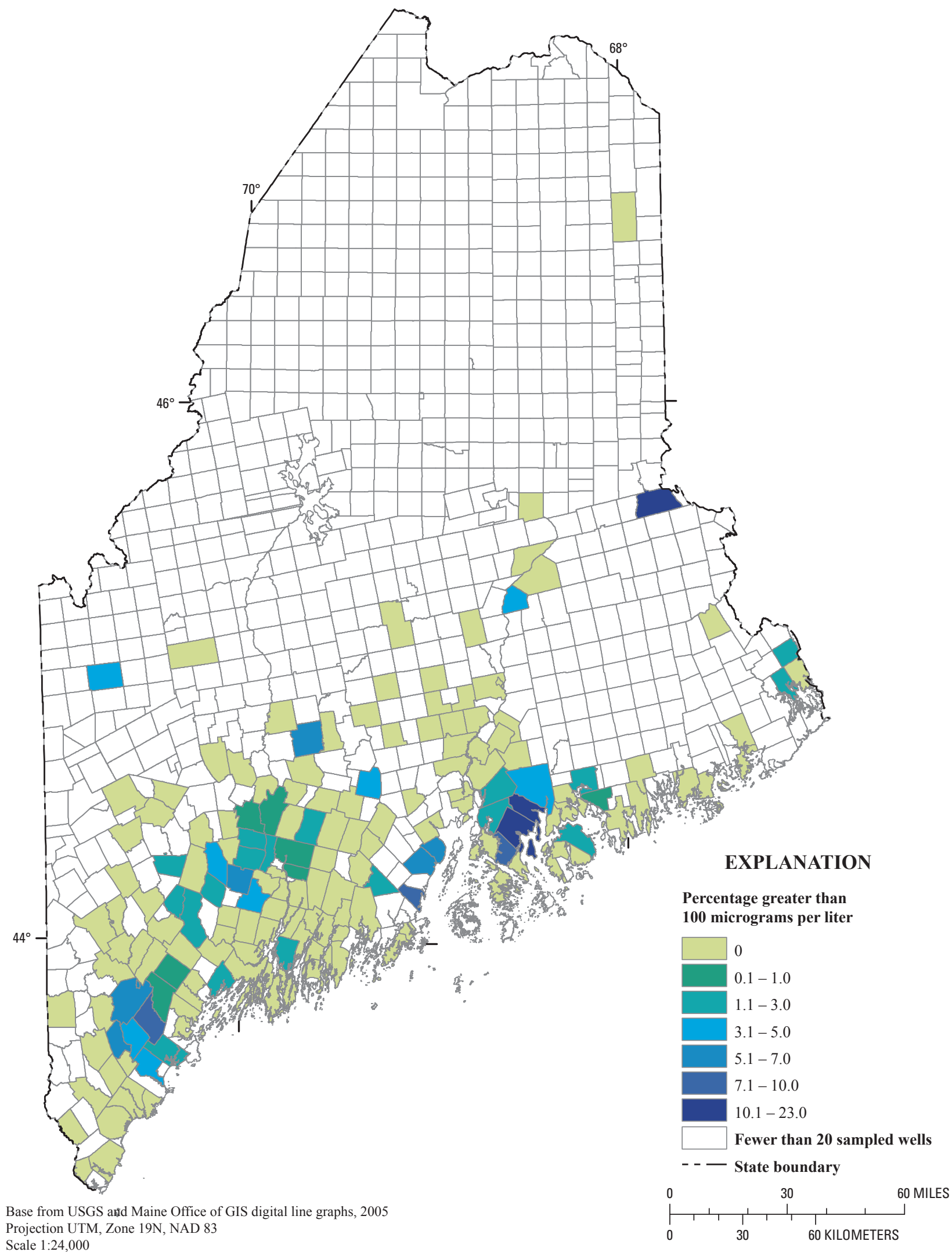

Figure 17. Percentage of wells in each town with arsenic concentrations greater than 100 micrograms per liter, in Maine, 2005-09. Towns shown have 20 or more sampled wells. 


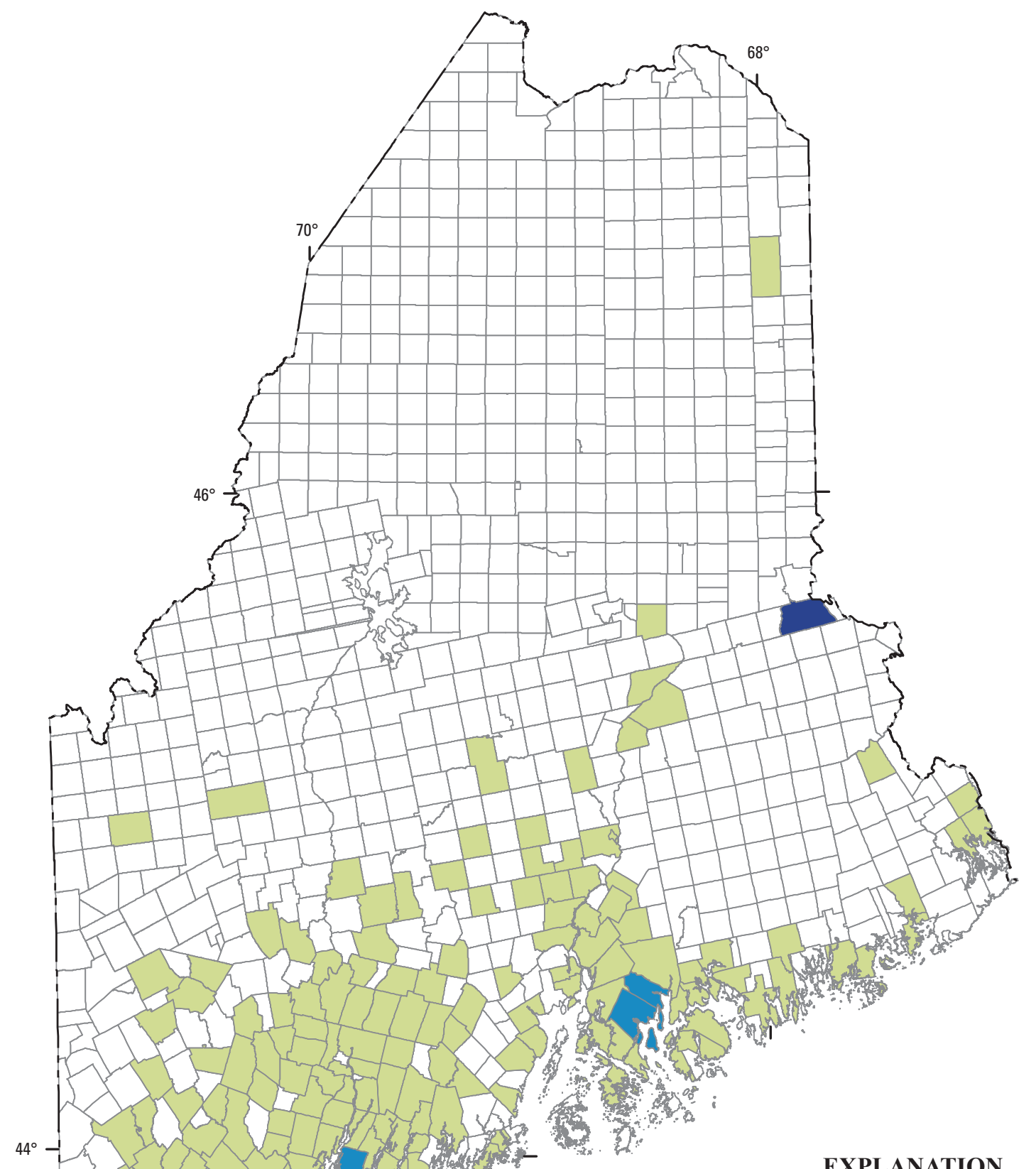

\section{EXPLANATION}

Percentage greater than $\mathbf{5 0 0}$ micrograms per liter

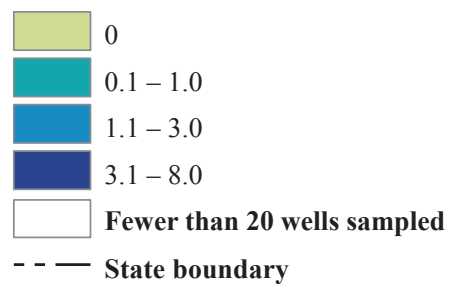

Base from USGS and Maine Office of GIS digital line graphs, 2005 Projection UTM, Zone 19N, NAD 83

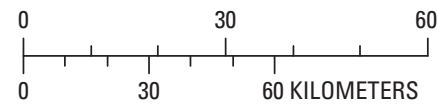
Scale 1:24,000

Figure 18. Percentage of wells in each town with arsenic concentrations greater than 500 micrograms per liter, in Maine, 2005-09. Towns shown have 20 or more sampled wells. 


\section{Cumulative Arsenic Distributions}

Many towns (49) in the study had more than 60 sampled wells recorded in the database, and cumulative distribution plots of arsenic were created for these towns. Cumulative distribution plots show all the samples collected in each town, arranged in order of increasing concentration and normalized to represent 100 percent of the samples, so the horizontal axis ranges from 0 to 1 percentile. In these graphs, samples with arsenic concentrations less than the detection limit of $0.5 \mu \mathrm{g} / \mathrm{L}$ are shown with a concentration of $0.1 \mu \mathrm{g} / \mathrm{L}$ so they stand out on the log-scale vertical axis. The shapes of the cumulative distribution plots can indicate more about the distribution of arsenic in each town than the overall summary statistics. After all 49 cumulative distribution graphs in towns with more than 60 samples were examined, several general patterns emerged as being representative of cumulative arsenic distributions for many towns. These patterns are illustrated in figure 19 and described below as types 1-4.

Type 1. Very low overall arsenic concentrations (less than the detection limit of $0.5 \mu \mathrm{g} / \mathrm{L}$ ), were present in more than half the samples from these towns, and none of the samples had concentrations greater than $50 \mu \mathrm{g} / \mathrm{L}$. The towns of Pittston and Naples represent this type of distribution (fig. 19A-B).

Type 2. Generally low concentrations were present in most samples (but greater than the detection limit); the graphs show an even rise in distribution with few samples greater than $50 \mu \mathrm{g} / \mathrm{L}$. This was a relatively uncommon distribution because of the heterogeneous nature of rock formations across town boundaries. The towns of Perry and Hermon represent this type (fig. 19C-D).

Type 3. Higher arsenic concentrations overall were present in most samples with few concentrations below the detection limit; an even rise to levels approaching $100 \mu \mathrm{g} / \mathrm{L}$ or more is shown in graphs of this type. The towns of Gorham and Surry represent this pattern (fig. 19E-F).

Type 4. Similar to type 3 , high arsenic concentrations were present in most samples with few values less than the detection limit. An even rise in the middle of the distribution and a distinct "tail" at the high end is shown in graphs of this type. The towns of Litchfield and Danforth represent this pattern (fig. 19G-H). This was a common pattern; many towns exhibit some kind of "tail" for a few extra-high concentrations at the upper end.

The likely difference between types 3 and 4 is that, in the towns with an even rise in concentrations (type 4), the arsenic concentrations in the bedrock are likely somewhat evenly distributed, but in towns with a "tail" (type 4) there is probably a pocket or small area in the town with very different geology from that in the rest of the town. The town of Danforth in far eastern Maine is one such town that is known to have a cluster of extremely high (in the thousands of $\mu \mathrm{g} / \mathrm{L}$ ) concentrations where the bedrock is distinctly different from that in other areas (Robert Marvinney, Maine Geological Survey, written commun., 2008).

\section{Summary and Conclusions}

High levels of arsenic in some domestic wells in Maine were recognized in the early 1990s, when the Maine Geological Survey and other State agencies published a report documenting high arsenic levels in domestic wells in the Buxton/Hollis area in southern Maine and the occurrence of high arsenic levels ( $>50 \mu \mathrm{g} / \mathrm{L})$ in geologically diverse areas across the State. Other previous studies have shown that elevated arsenic concentrations in Maine appear to be clustered in areas from a few kilometers to tens of kilometers across, and maximum arsenic concentrations in these clusters range from hundreds to thousands of micrograms per liter. It is important to identify the small, extreme-concentration clusters within the State so that public education efforts can ensure that domestic wells are tested, and wells with high concentrations of arsenic are treated.

The database used for this analysis was compiled from the results of water samples submitted for arsenic analysis by homeowners, real estate agents (for clients), and a few State agencies to the Maine Health and Environmental Testing laboratory (HETL) in Augusta. For this database analysis, more than 18,000 records of arsenic in water from 11,111 wells in the State were screened and analyzed. Because of the personally identifiable information contained in the sample set, all screening work on these data was performed within the ME-CDC offices, using ME-CDC computers, according to ME-CDC confidentiality requirements. Once the screening was completed, all personal information was removed. The data screening and coding included (1) removing duplicate samples, (2) determining the minor civil division (town) in which the sample was collected, (3) removing data that probably did not pertain to domestic well-water samples (even though the data passed the initial data screening step), (4) determining which samples in each town probably were either repeat samples from the same well or were unique samples from individual wells, and (5) determining what was known about the filtration (water treatment) of the sample. Once the data were cleaned and sorted, they were reduced to one value per well.

In order to investigate the possibility of a self-selection bias, the rate of well sampling in each town was plotted against the median and maximum arsenic concentrations. Although the data available do not appear to indicate that there is a high degree of self-selection bias in the medians of the town arsenic concentrations or bias from outreach by the ME-CDC, neither do the data rule out the possibility of some degree of bias when compared to a randomly designed sampling of wells in Maine, especially as it pertains to the representativeness of the maximum arsenic concentration in towns that have relatively few samples. Another way to look at the representativeness of samples submitted to the HETL for analysis is to consider the overall number of samples in the dataset. Towns with higher numbers of samples probably have data that better represent the range of conditions 


\section{A Pittston}
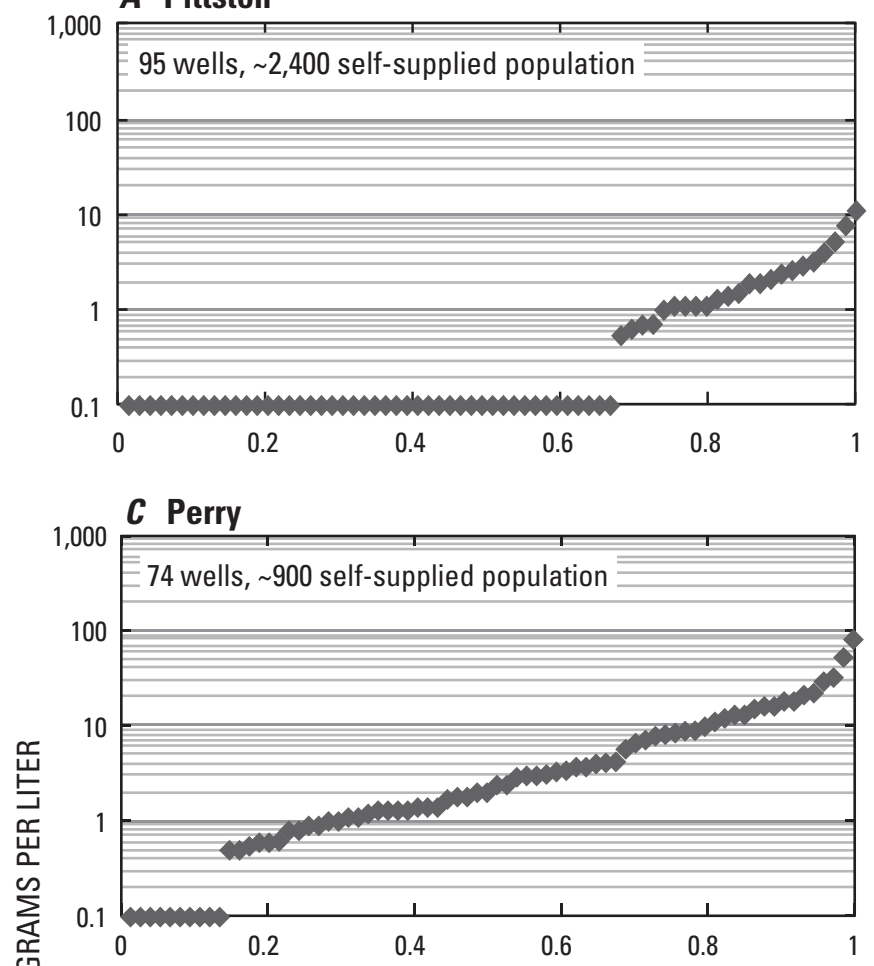

\section{E Gorham}

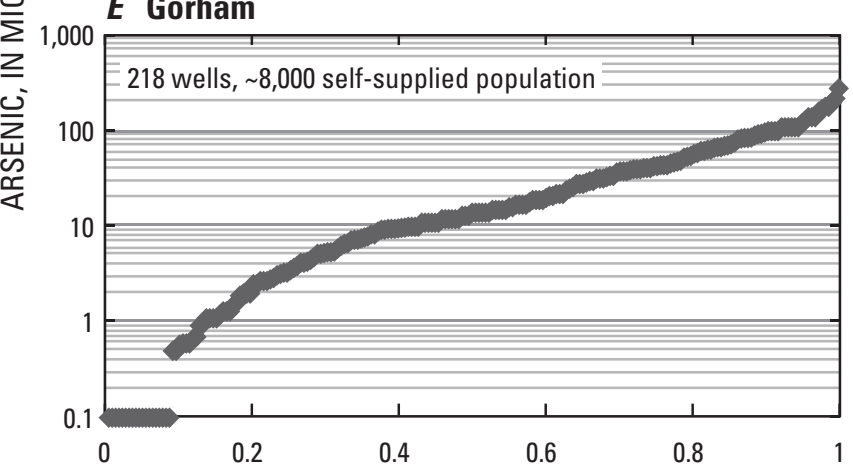

G Litchfield

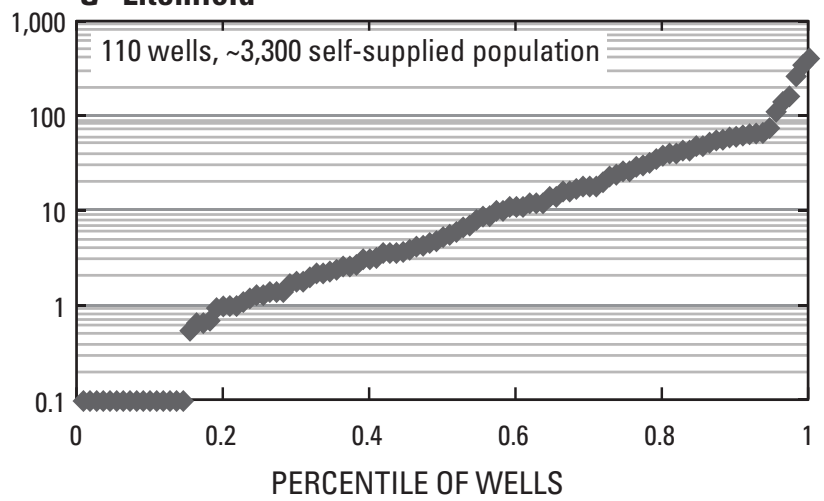

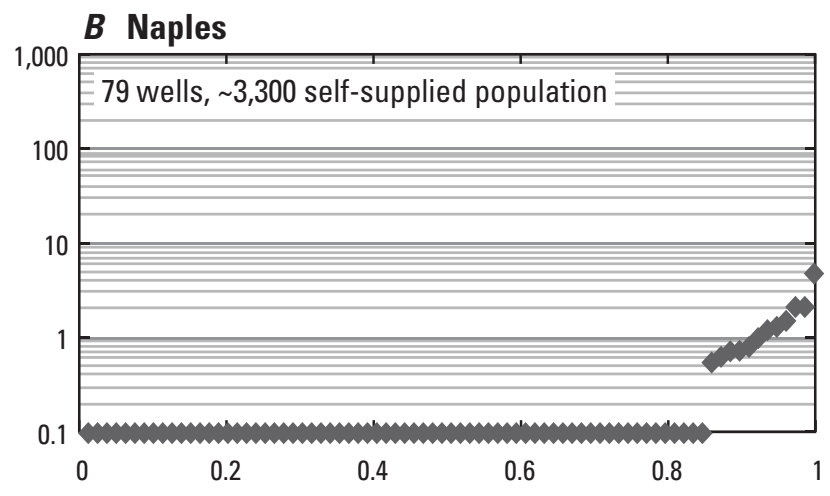

D Hermon
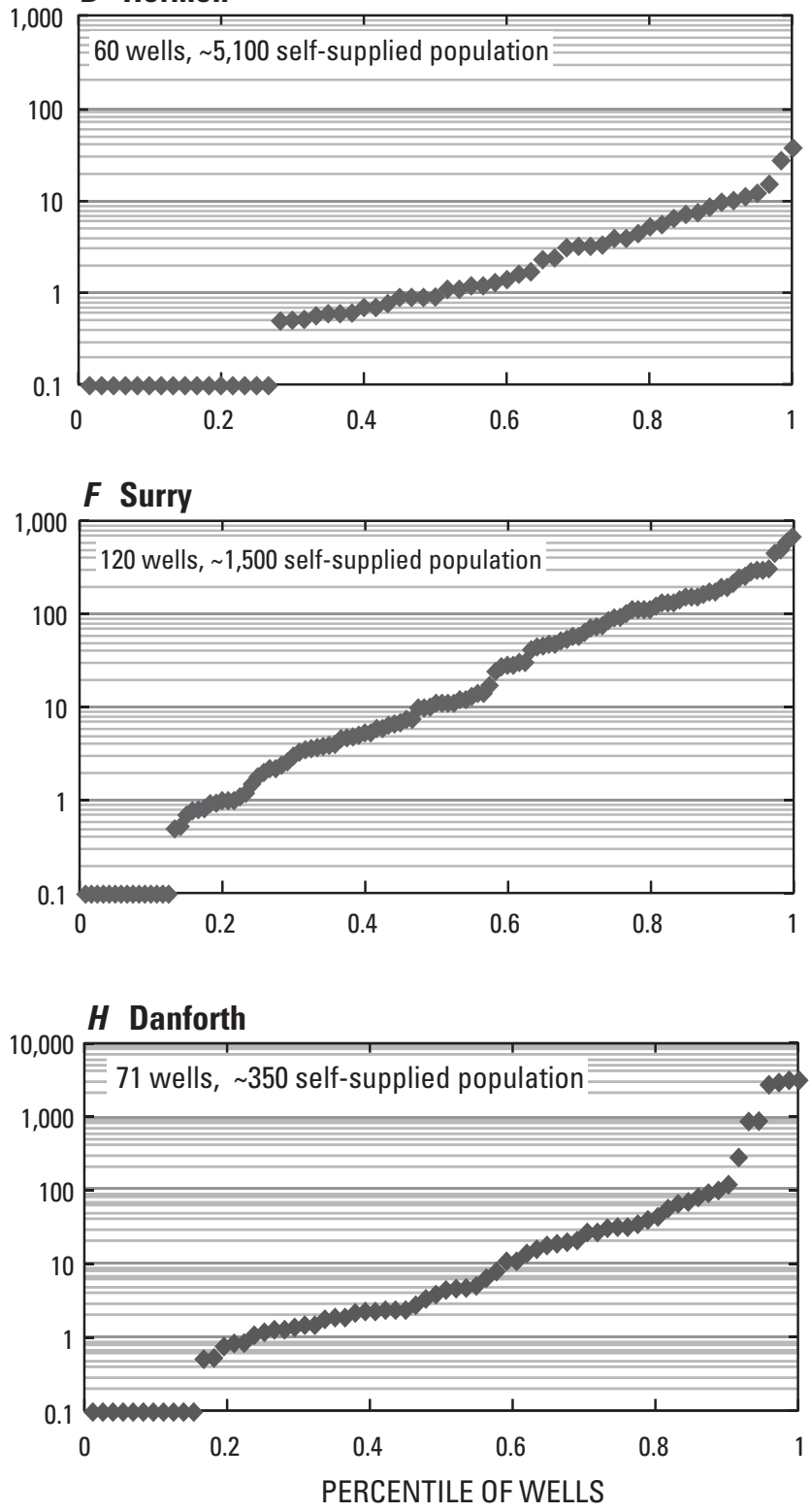

Figure 19. Cumulative distribution plot types $1(A-B), 2(C-D), 3(E-F)$, and $4(G-H)$ for arsenic in wells in Maine, 2005-09. Values less than detection limit $(<0.5)$ plot as 0.1 . See text discussion for plot types. 
in those towns. Towns with very few samples would need additional testing to better understand the range of arsenic concentrations in homeowner wells.

The goal of using samples that represented "raw" groundwater, or at least groundwater that was not treated to remove arsenic, determined how the available information on water treatment or filtration was utilized, particularly when deciding how to aggregate multiple samples per well to one representative value. (Although 84 percent of the wells had only 1 sample in the database, the remaining 16 percent had from 2 to 6 samples.) There were several options for handling multiple samples at a well: average the values to get a "composite" concentration; take the sample that was collected first, as these were often the highest concentrations used to determine whether a treatment system was necessary (subsequent samples often were collected to test the efficacy of a treatment system); or select one sample (unfiltered if possible) from each well. If all the variations in arsenic concentrations at a well were due only to natural variation, taking the average would result in a representative concentration for that well, but because of the mix of filtered and unfiltered samples (and not knowing necessarily which was which), the more conservative and simple approach was to take the maximum concentration at each well.

Beyond the factors listed above, when using a dataset such as the HETL for scientific studies, ideally, caution should be exercised in the use and interpretation of the data because of the inherent uncertainties in the demographic information and other variables that go along with each sample. The physical address of each sample is often unknown because only 56 percent of the samples had street addresses that match the sample town location. (Most of the rest did not have a street address.) Also, the database does not differentiate between samples collected from different wells on the same property.

Five hundred thirty-one of Maine's 908 minor civil divisions (488 organized municipalities and 420 unorganized territories - all referred to as "towns" in this report) are represented in the dataset. Overall, 18.4 percent of wells had arsenic concentrations greater than $10 \mu \mathrm{g} / \mathrm{L}$ in the entire database, and 4 percent of the sampled wells had concentrations greater than $50 \mu \mathrm{g} / \mathrm{L}$. These data do not represent a random sample of wells from each town; rather, they provide the best indicator of high concentrations, by town, of any available datasets and are a better indicator of arsenic hot spots than data from randomly designed studies. Sampling density is greatest in areas with known high levels of arsenic. Towns with very low populations and towns with well-recognized arsenic issues have greater sample representation (per capita) in the database than areas with greater populations and less data on arsenic occurrence or few arsenic issues. The 30 highest maximum arsenic concentrations in towns in this dataset range from 200 to $3,100 \mu \mathrm{g} / \mathrm{L}$, and the 30 highest median arsenic concentrations (by town) range from 5.5 to $22 \mu \mathrm{g} / \mathrm{L}$. Many of the towns in these two lists could be considered well characterized because samples were obtained from more than 40 wells in these towns. However, there are several towns in the highest groups with samples from fewer than 10 wells, such as the towns of Seboeis Plantation, Atkinson, Passadumkeag, Anson, and Monson. These towns are not heavily populated, but the relatively high concentrations of arsenic in these towns may deserve further investigation.

There appear to be three distinct large-scale areas of high arsenic concentrations - one in south coastal areas, one in central Kennebec County west of Augusta, and one in Ellsworth and surrounding towns - and several smaller clusters of isolated high-arsenic zones. The clusters in the areas around Augusta and Ellsworth, and the cluster in southern coastal Maine, are all well characterized, as the towns in these areas are represented by many samples in the dataset, and arsenic has been well documented in past studies.

In eleven towns, over 40 percent of wells had concentrations over $10 \mu \mathrm{g} / \mathrm{L}$. Because these towns had from 60 to 218 samples each, these towns could be considered well characterized. Many fewer towns had wells with arsenic concentrations exceeding 50, 100, or $500 \mu \mathrm{g} / \mathrm{L}$. Only 19 towns had more than 10 percent of wells with concentrations exceeding $50 \mu \mathrm{g} / \mathrm{L}$, and 44 towns had 1 percent or more exceeding $100 \mu \mathrm{g} / \mathrm{L}$. Of these, in Surry, Hancock County, 23 percent of the 120 wells tested exceeded $100 \mu \mathrm{g} / \mathrm{L}$ of arsenic, which is a much higher rate than for other towns. Only four towns (Danforth in Washington County, Surry and Blue Hill in Hancock County, and Woolwich in Sagadahoc County) had 1 percent or more of wells with greater than $500 \mu \mathrm{g} / \mathrm{L}$ of arsenic during 2005-09. Earlier testing found other clusters of very high arsenic levels in Northport, the Buxton/Hollis area, and Waldoboro, but those samples were collected before 2005 and did not factor into this analysis.

The spatial distribution of the percentage of wells exceeding $10 \mu \mathrm{g} / \mathrm{L}$ was compared to a previously published logisticregression model of the probability of finding elevated arsenic in bedrock wells in Maine. In some areas of the State, the model and the data distribution were in agreement, particularly in southern Oxford County/western Cumberland County and in Hancock County near Ellsworth and Blue Hill. However, in other areas the data and the model did not agree. As these data were not collected for the purposes of validating the model, and they use different concentration thresholds, it is difficult to draw specific conclusions from any differences between them.

\section{Acknowledgments}

Members of the staff at the ME-CDC were very accommodating during the data screening process. Dr. Andrew Smith, Maine State Toxicologist, and Dr. Christopher Paulu of the ME-CDC collaborated extensively in the treatment of filtered samples and replicates; Dr. Paulu was also instrumental in the data retrieval process. Charles Culbertson and Charles Schalk of the USGS provided data on the quality control/quality assurance aspects of the laboratory analyses. 


\section{References Cited}

Ayotte, J.D., Montgomery, D.L., Flanagan, S.M., and Robinson, K.W., 2003, Arsenic in groundwater in Eastern New England: occurrence, controls, and human health implications: Environmental Science and Technology, v. 37 , no. 10 , p. 2075-2083.

Ayotte, J.D., Nielsen, M.G., Robinson, G.P., Jr., and Moore, R.B., 1999, Relation of arsenic, iron, and manganese in ground water to aquifer type, bedrock lithogeochemistry, and land use in the New England Coastal Basins: U.S. Geological Survey WaterResources Investigations Report 99-4162, 61 p.

Ayotte, J.D., Nolan, B.T., Nuckols, J.R., Cantor, K.P., Robinson, G.P., Jr., Baris, D., Hayes, L., Karagas, M., Bress, W., Silverman, D.T., and Lubin, J.H., 2006, Modeling the probability of arsenic in groundwater in New England as a tool for exposure assessment: Environmental Science and Technology, v. 40, no. 11, p. 3578-3585.

The Brookings Institution, 2006, Charting Maine's futureAn action plan for promoting sustainable prosperity and quality places: Washington, D.C., The Brookings Institution Metropolitan Policy Program, 144 p.

D’Angelo, D., Norton, S.A., and Loiselle, M.C., 1996, Historical uses and fate of arsenic in Maine. Water Research Institute Completion Report 1986: Orono, Maine, University of Maine, $24 \mathrm{p}$.

Focazio, M.J., Welch, A.H., Watkins, S.A., Helsel, D.R., and Horn, M.A., 1999, A retrospective analysis on the occurrence of arsenic in groundwater resources of the United States and limitations in drinking-water-supply characterizations: U.S. Geological Survey Water-Resources Investigations Report 99-4279, 21 p.

Lipfert, G., Reeve, A.S., Sidle, W.C., and Marvinney, R., 2006, Geochemical patterns of arsenic-enriched groundwater in fractured, crystalline bedrock, Northport, Maine, USA: Applied Geochemistry, v. 21, p. 528-545.

Loiselle, M.C., Marvinney, R.G., and Smith, A.E., 2001, Spatial distribution of arsenic in groundwater in Maine: Geological Society of America, 2001 Annual Meeting, Boston, Mass., 2001, Geological Society of America, November 5-8, 2001.

Marvinney, R.G., Loiselle, M.C., Hopeck, J.T., Braley, D., and Krueger, J.A., 1994, Arsenic in Maine groundwater: an example from Buxton, Maine: National Ground Water Association 1994 Focus Conference on Eastern Regional Groundwater Issues, National Ground Water Association, Burlington, Vt., p. 701-715.
Peters, S.C., 2008, Arsenic in groundwaters in the northern Appalachian mountain belt: a review of patterns and processes: Journal of Contaminant Hydrology, v. 99, p. 8-21.

Peters, S.C., Blum, J.D., Klaue, B., and Karagas, M.R., 1999, Arsenic occurrence in New Hampshire drinking water: Environmental Science and Technology, v. 33, no. 9, p. $1328-1333$.

Robinson, G.P., Jr., and Ayotte, J.D., 2006, The influence of geology and land use on arsenic in stream sediments and groundwaters in New England, USA: Applied Geochemistry, v. 21, p. $1482-1497$.

Shapiro, S.S., and Francia, R.S., 1972, An approximate analysis of variance test for normality: Journal of the American Statistical Association, v. 63, p. 1343-1372.

Sidle, W.C., 2003, Identifying discharge zones of arsenic in the Goose River Basin, Maine: Journal of the American Water Resources Association, v. 39, no. 5, p. 1067-1077.

Sidle, W.C., Wotten, B., and Murphy, E., 2001, Provenance of geogenic arsenic in the Goose River basin, Maine, USA: Environmental Geology, v. 41, p. 62-73.

U.S. Census Bureau, 1990, 1990 Summary tape File 3 (STF-3) sample data, Table DP-5. Housing Characteristics: 1990.

U.S. Census Bureau, 2000, Demographic profiles: 100-percent and sample data, Table DP-1. Profile of general demographic characteristics: 2000. Data from Maine State Planning Office, accessed March 1, 2010, at http://maine.gov/spo/economics/ docs/census/prof1_4datame.xls.

U.S. Census Bureau, 2008, Census Bureau annual estimates of population of Maine towns and counties, April 2000-July 2008 Table 5: Annual estimates of the resident population for Minor Civil Divisions in Maine, listed alphabetically within county: April 1, 2000 to July 1, 2008 (SUB-EST2008-05-23). Source: Population Division, U.S. Census Bureau. Release date: July 1, 2009, accessed November 20, 2009, at http:/www.maine. gov/spo/economics/docs/townleveldata/mcdpop2000-08.xls.

U.S. Environmental Protection Agency, 2001, National primary drinking water regulations: Arsenic and clarifications to compliance and new source contaminants monitoring: Final Rule Federal Register 2001, v. 66, no. 14, p. 6976-7066.

U.S. Geological Survey, 2005, Water use compilation for Maine: unpublished data on file at the USGS offices in Augusta, Maine.

Yang, Q., Jung, H.B., Culbertson, C.W., Marvinney, R.G., Loiselle, M.C., Locke, D.B., Cheek, H., Thibodeau, H., and Zheng, Y., 2009, Spatial pattern of groundwater arsenic occurrence and association with bedrock geology in greater Augusta, Maine: Environmental Science and Technology, v. 43 , p. 2714-2719. 


\section{Appendixes 1-3}

Appendix 1. Demographic Data for Towns in Maine .................................................................38

Appendix 2. Numbers of Samples and Wells with Samples, by Town, in Maine, and Minimum, Maximum, and Median Arsenic Concentrations in Each Town with Samples in the Maine Health and Environmental Testing Laboratory Database, 2005-09.......................50

Appendix 3. Exceedence Percentages for Towns with More than 20 Wells Sampled for Arsenic, from Samples in the Maine Health and Environmental Testing Laboratory Database, 2005-09... 
Appendix 1. Demographic data for towns in Maine.

[Plt, Plantation; UT, Unincorporated Territory; Twp, Township; NA, not available]

\begin{tabular}{|c|c|c|c|c|c|}
\hline Town or county subdivision & $\begin{array}{c}\text { Population', } \\
2008\end{array}$ & $\begin{array}{c}\text { Population } \\
\text { per household }{ }^{2} \text {, } \\
2000\end{array}$ & $\begin{array}{c}\text { Estimated } \\
\text { number of } \\
\text { households }^{3} \text {, } \\
2008\end{array}$ & $\begin{array}{c}\text { Precentage of } \\
\text { self-supplied } \\
\text { households } \\
1990\end{array}$ & $\begin{array}{c}\text { Estimated } \\
\text { number of } \\
\text { self-supplied } \\
\text { households } \\
2008 \\
\end{array}$ \\
\hline \multicolumn{6}{|c|}{ Androscoggin County } \\
\hline Auburn & 23,177 & 2.38 & 9,753 & 12.9 & 1,258 \\
\hline Leeds & 2,135 & 2.72 & 785 & 98.6 & 774 \\
\hline Lewiston & 35,131 & 2.33 & 15,050 & 3.0 & 451 \\
\hline Lisbon & 9,316 & 2.52 & 3,702 & 15.5 & 573 \\
\hline Livermore & 2,204 & 2.50 & 881 & 97.6 & 859 \\
\hline Livermore Falls & 3,134 & 2.44 & 1,283 & 23.5 & 301 \\
\hline Sabattus & 4,648 & 2.63 & 1,769 & 58.9 & 1,041 \\
\hline Turner & 5,575 & 2.81 & 1,982 & 96.4 & 1,910 \\
\hline Wales & 1,481 & 2.82 & 524 & 88.1 & 461 \\
\hline \multicolumn{6}{|c|}{ Aroostook County } \\
\hline Allagash & 269 & 1.98 & 135 & 97.6 & 131 \\
\hline Amity & 206 & 2.58 & 79 & 100 & 79 \\
\hline Ashland & 1,444 & 2.34 & 616 & 53.1 & 327 \\
\hline Bancroft & 58 & 2.54 & 22 & 100 & 22 \\
\hline Blaine & 795 & 2.58 & 308 & 60.4 & 186 \\
\hline Bridgewater & 578 & 2.47 & 234 & 97.9 & 229 \\
\hline Caribou & 8,093 & 2.36 & 3,424 & 40.6 & 1,390 \\
\hline Crystal & 271 & 2.54 & 106 & 100 & 106 \\
\hline Cyr Plt & 111 & 2.79 & 39 & 87.0 & 33 \\
\hline Dyer Brook & 207 & 2.52 & 82 & 100 & 82 \\
\hline Eagle Lake & 785 & 2.47 & 317 & 49.8 & 157 \\
\hline Easton & 1,185 & 2.38 & 497 & 95.1 & 472 \\
\hline Fort Fairfield & 3,450 & 2.35 & 1,468 & 42.9 & 629 \\
\hline Fort Kent & 4,182 & 2.44 & 1,714 & 51.6 & 884 \\
\hline Frenchville & 1,198 & 2.56 & 467 & 98.5 & 459 \\
\hline Garfield Plt & 82 & 2.32 & 35 & 100 & 35 \\
\hline Glenwood Plt & 1 & NA & NA & 100 & NA \\
\hline Grand Isle & 490 & 2.38 & 206 & 100 & 206 \\
\hline Hamlin & 244 & 2.50 & 97 & 88.0 & 85 \\
\hline Hammond & 94 & 2.97 & 31 & 100 & 31 \\
\hline Haynesville & 121 & 2.71 & 44 & 100 & 44 \\
\hline Hersey & 62 & 2.25 & 27 & 100 & 27 \\
\hline Hodgdon & 1,248 & 2.68 & 464 & 100 & 464 \\
\hline Houlton & 6,144 & 2.42 & 2,539 & 14.1 & 357 \\
\hline Island Falls & 748 & 2.29 & 326 & 53.1 & 173 \\
\hline
\end{tabular}


Appendix 1. Demographic data for towns in Maine.-Continued

[Plt, Plantation; UT, Unincorporated Territory; Twp, Township; NA, not available]

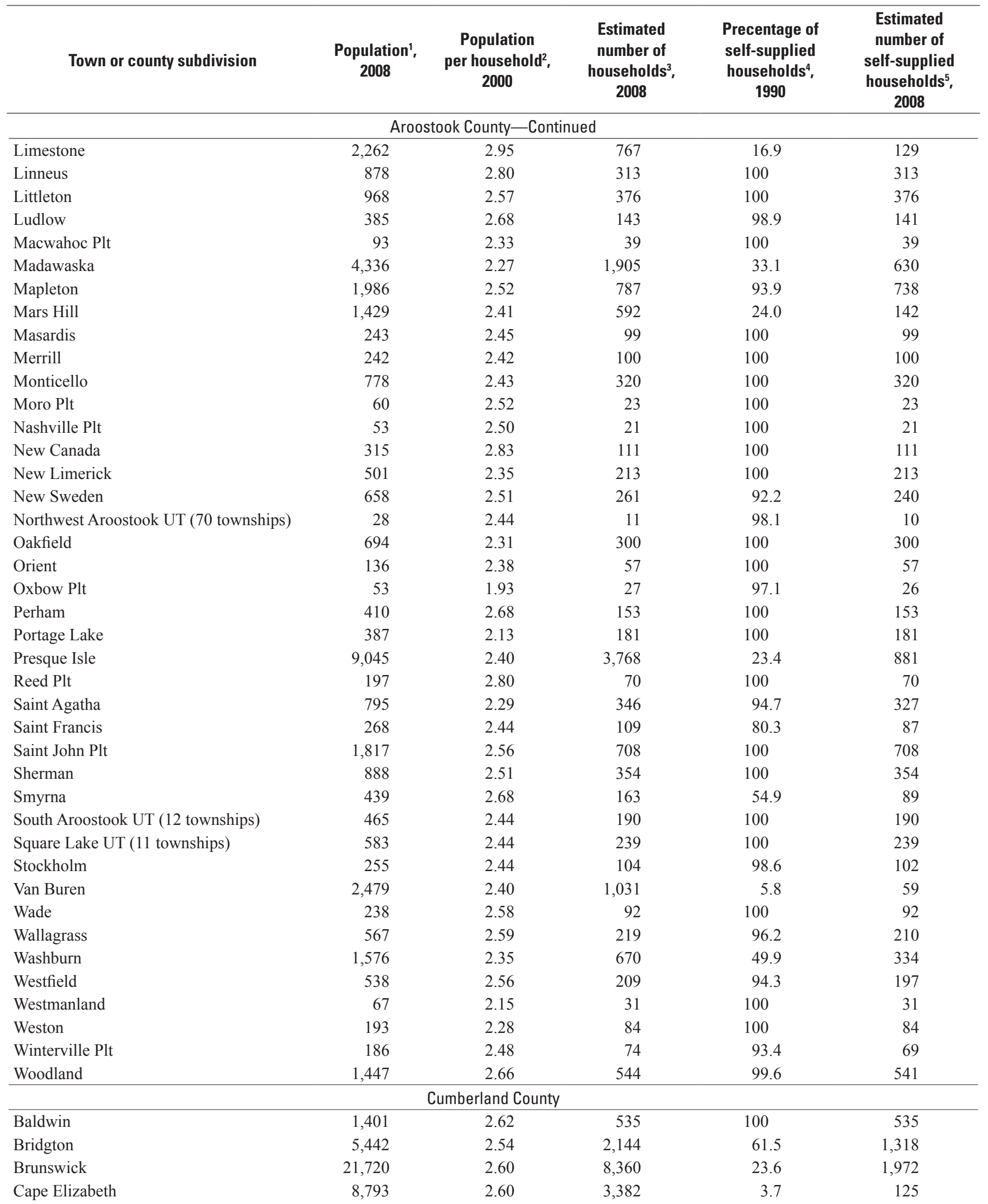


Appendix 1. Demographic data for towns in Maine.-Continued

[Plt, Plantation; UT, Unincorporated Territory; Twp, Township; NA, not available]

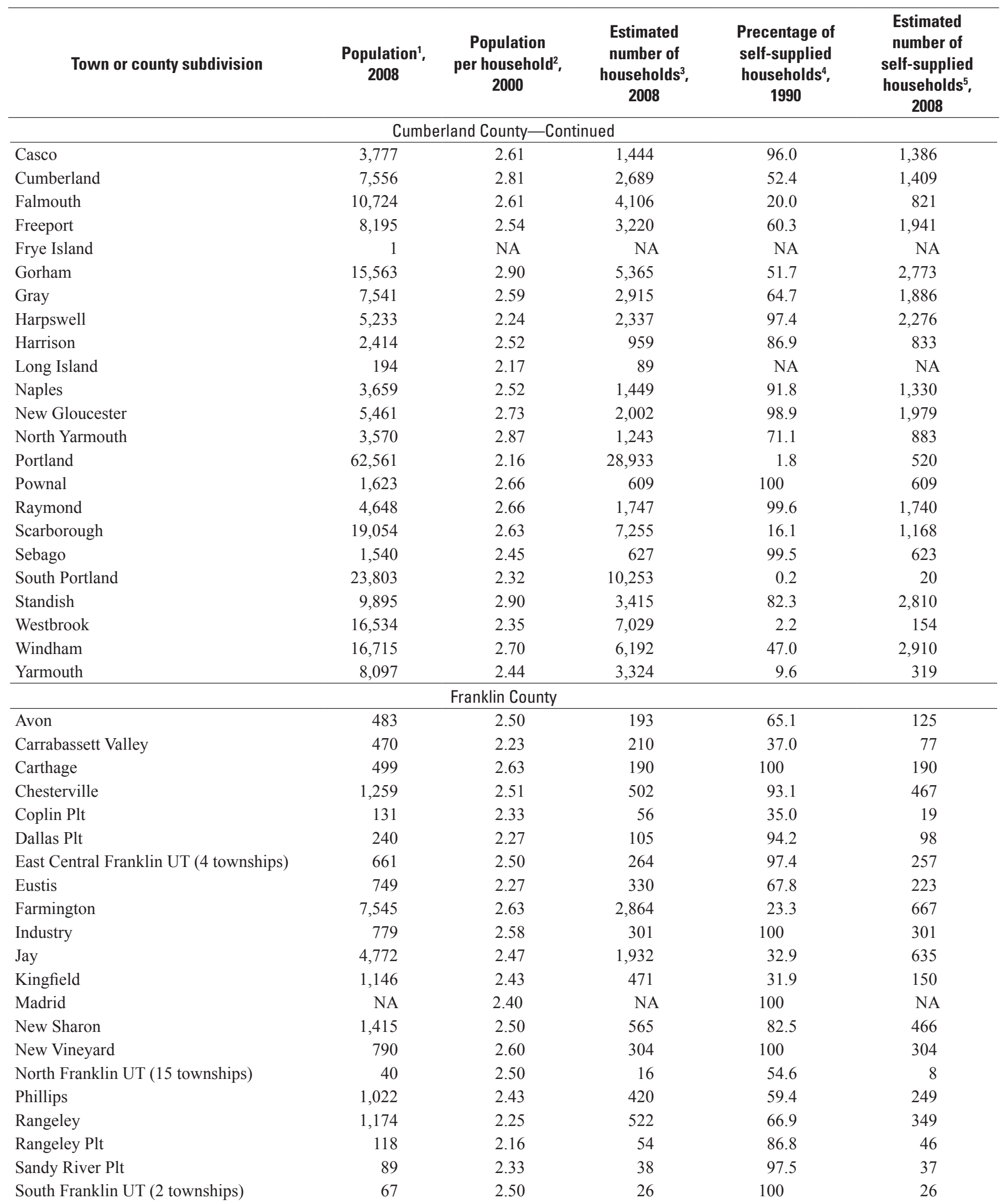


Appendix 1. Demographic data for towns in Maine.-Continued

[Plt, Plantation; UT, Unincorporated Territory; Twp, Township; NA, not available]

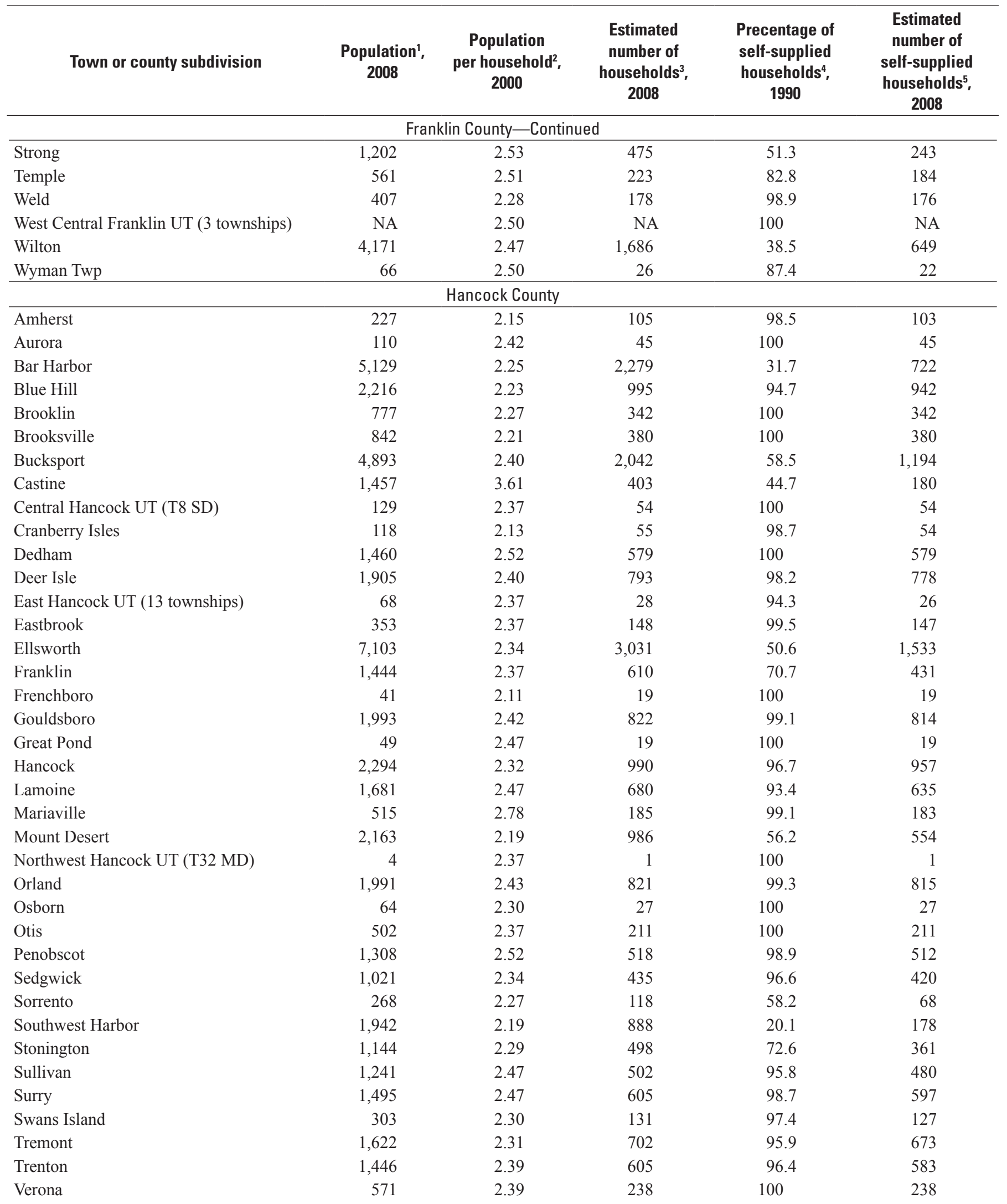


Appendix 1. Demographic data for towns in Maine.-Continued

[Plt, Plantation; UT, Unincorporated Territory; Twp, Township; NA, not available]

\begin{tabular}{|c|c|c|c|c|c|}
\hline Town or county subdivision & $\begin{array}{c}\text { Population' } \\
2008\end{array}$ & $\begin{array}{c}\text { Population } \\
\text { per household², } \\
2000\end{array}$ & $\begin{array}{c}\text { Estimated } \\
\text { number of } \\
\text { households }{ }^{3} \text {, } \\
2008\end{array}$ & $\begin{array}{c}\text { Precentage of } \\
\text { self-supplied } \\
\text { households } \\
1990\end{array}$ & $\begin{array}{c}\text { Estimated } \\
\text { number of } \\
\text { self-supplied } \\
\text { households } \\
2008\end{array}$ \\
\hline \multicolumn{6}{|c|}{ Hancock County-Continued } \\
\hline Waltham & 284 & 2.76 & 103 & 100 & 103 \\
\hline \multicolumn{6}{|c|}{ Kennebec County } \\
\hline Albion & 2,155 & 2.71 & 796 & 99.0 & 788 \\
\hline Augusta & 18,282 & 2.17 & 8,436 & 17.4 & 1,467 \\
\hline Belgrade & 3,213 & 2.53 & 1,270 & 96.8 & 1,229 \\
\hline Benton & 2,685 & 2.52 & 1,063 & 68.6 & 729 \\
\hline Chelsea & 2,638 & 2.67 & 988 & 97.7 & 965 \\
\hline Fayette & 1,178 & 2.49 & 472 & 98.9 & 466 \\
\hline Gardiner & 6,100 & 2.47 & 2,470 & 7.9 & 195 \\
\hline Hallowell & 2,437 & 2.15 & 1,131 & 11.9 & 134 \\
\hline Litchfield & 3,455 & 2.61 & 1,322 & 94.3 & 1,246 \\
\hline Manchester & 2,561 & 2.52 & 1,015 & 67.1 & 681 \\
\hline Monmouth & 3,855 & 2.64 & 1,461 & 78.8 & 1,151 \\
\hline Mount Vernon & 1,667 & 2.53 & 659 & 98.1 & 646 \\
\hline Oakland & 6,184 & 2.53 & 2,440 & 52.4 & 1,278 \\
\hline Pittston & 2,629 & 2.52 & 1,042 & 90.1 & 938 \\
\hline Randolph & 1,855 & 2.31 & 804 & 0.9 & 7 \\
\hline Readfield & 2,570 & 2.72 & 944 & 96.9 & 914 \\
\hline Wayne & 1,180 & 2.39 & 493 & 100 & 493 \\
\hline West Gardiner & 2,813 & 2.60 & 1,080 & 98.2 & 1,060 \\
\hline Windsor & 2,369 & 2.61 & 909 & 97.4 & 885 \\
\hline Winslow & 7,845 & 2.37 & 3,311 & 27.6 & 913 \\
\hline Winthrop & 6,429 & 2.50 & 2,573 & 45.5 & 1,170 \\
\hline \multicolumn{6}{|c|}{ Knox County } \\
\hline Appleton & 1,306 & 2.65 & 493 & 99.8 & 492 \\
\hline Camden & 5,220 & 2.20 & 2,374 & 28.0 & 664 \\
\hline Cushing & 1,244 & 2.44 & 509 & 100 & 509 \\
\hline Friendship & 1,194 & 2.37 & 503 & 96.3 & 484 \\
\hline Hope & 1,447 & 2.55 & 566 & 99.6 & 563 \\
\hline Isle Au Haut & 74 & 2.47 & 29 & 75.0 & 21 \\
\hline Matinicus Isle Plt & 47 & 1.96 & 23 & 100 & 23 \\
\hline North Haven & 380 & 2.35 & 161 & 39.9 & 64 \\
\hline Owls Head & 1,632 & 2.21 & 736 & 81.6 & 600 \\
\hline Rockland & 7,436 & 2.22 & 3,355 & 2.8 & 93 \\
\hline Rockport & 3,518 & 2.34 & 1,505 & 41.2 & 620 \\
\hline Saint George & 2,693 & 2.31 & 1,168 & 93.4 & 1,090 \\
\hline
\end{tabular}


Appendix 1. Demographic data for towns in Maine.-Continued

[Plt, Plantation; UT, Unincorporated Territory; Twp, Township; NA, not available]

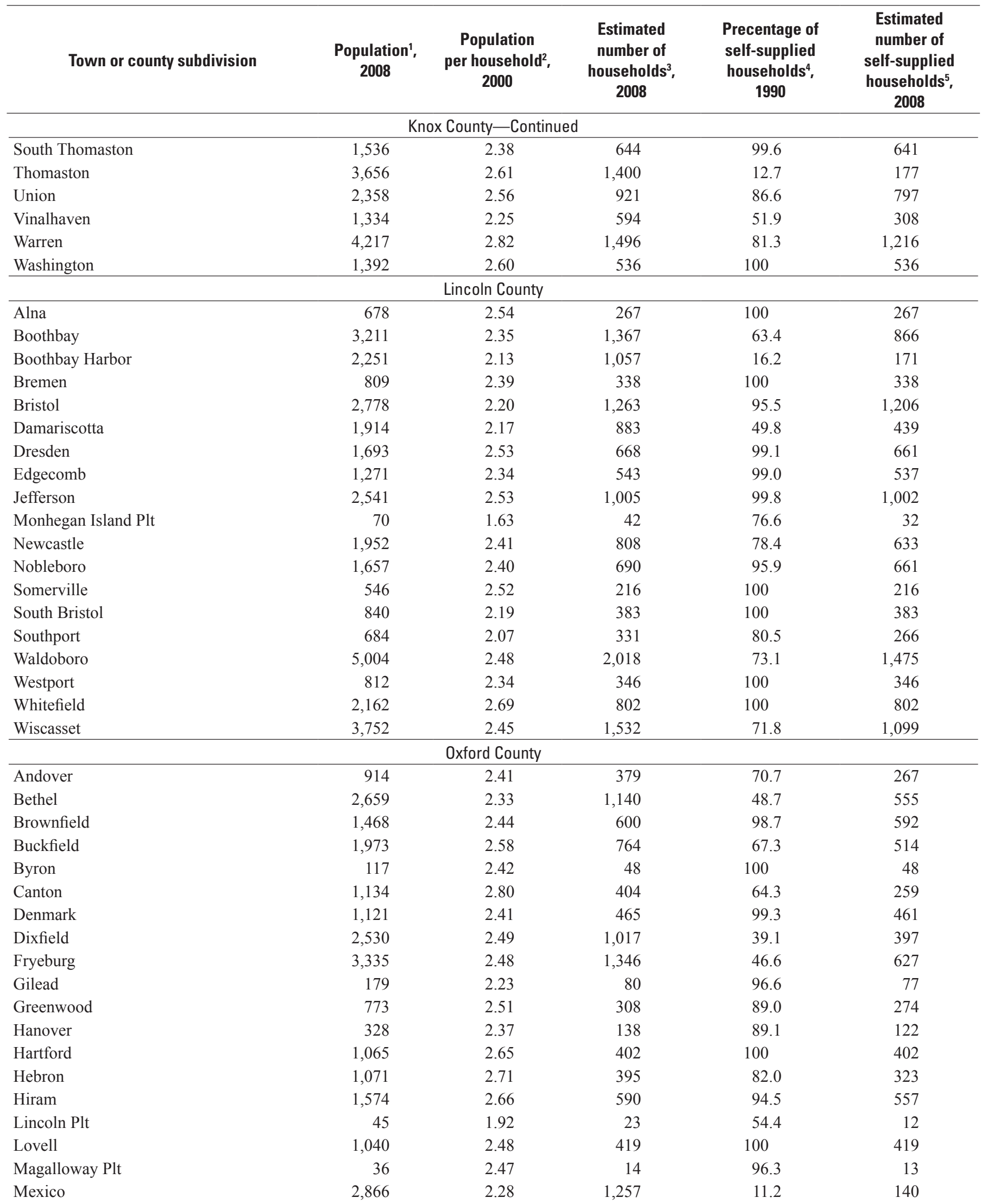


Appendix 1. Demographic data for towns in Maine.-Continued

[Plt, Plantation; UT, Unincorporated Territory; Twp, Township; NA, not available]

\begin{tabular}{|c|c|c|c|c|c|}
\hline Town or county subdivision & $\begin{array}{c}\text { Population' } \\
2008\end{array}$ & $\begin{array}{c}\text { Population } \\
\text { per household }{ }^{2} \text {, } \\
2000\end{array}$ & $\begin{array}{c}\text { Estimated } \\
\text { number of } \\
\text { households }{ }^{3} \text {, } \\
2008\end{array}$ & $\begin{array}{c}\text { Precentage of } \\
\text { self-supplied } \\
\text { households } \\
1990\end{array}$ & $\begin{array}{c}\text { Estimated } \\
\text { number of } \\
\text { self-supplied } \\
\text { households } \\
2008\end{array}$ \\
\hline \multicolumn{6}{|c|}{ Oxford County-Continued } \\
\hline Milton Twp & 114 & 2.45 & 46 & 100 & 46 \\
\hline Norway & 4,762 & 2.34 & 2,036 & 47.7 & 971 \\
\hline Otisfield & 1,692 & 2.62 & 645 & 100 & 645 \\
\hline Oxford & 3,926 & 2.66 & 1,474 & 71.5 & 1,053 \\
\hline Paris & 4,962 & 2.43 & 2,044 & 34.6 & 707 \\
\hline Peru & 1,537 & 2.59 & 593 & 99.8 & 591 \\
\hline Stoneham & 276 & 2.26 & 122 & 79.7 & 97 \\
\hline Stow & 371 & 2.50 & 148 & 100 & 148 \\
\hline Sumner & 821 & 2.59 & 317 & 99.3 & 314 \\
\hline Sweden & 370 & 2.45 & 150 & 97.4 & 146 \\
\hline Upton & 61 & 1.88 & 32 & 100 & 32 \\
\hline Waterford & 1,507 & 2.47 & 611 & 100 & 611 \\
\hline West Paris & 1,665 & 2.67 & 624 & 57.7 & 360 \\
\hline Woodstock & 1,374 & 2.49 & 551 & 98.4 & 542 \\
\hline \multicolumn{6}{|c|}{ Penobscot County } \\
\hline Alton & 859 & 2.64 & 325 & 100 & 325 \\
\hline Carmel & 2,645 & 2.59 & 1,020 & 98.4 & 1,003 \\
\hline Carroll Plt & 138 & 2.44 & 56 & 100 & 56 \\
\hline Charleston & 1,365 & 3.24 & 421 & 95.2 & 400 \\
\hline Chester & 504 & 2.61 & 192 & 100 & 192 \\
\hline Clifton & 790 & 2.45 & 322 & 98.9 & 318 \\
\hline Corinna & 2,303 & 2.55 & 904 & 96.3 & 870 \\
\hline Corinth & 2,706 & 2.62 & 1,033 & 95.4 & 985 \\
\hline Dexter & 3,687 & 2.41 & 1,530 & 38.6 & 590 \\
\hline Dixmont & 1,043 & 2.59 & 402 & 100 & 402 \\
\hline Drew Plt & 55 & 3.35 & 16 & 100 & 16 \\
\hline East Central Penobscot UT (3 townships) & 312 & 2.49 & 125 & 100 & 125 \\
\hline East Millinocket & 1,723 & 2.34 & 735 & 0.9 & 6 \\
\hline Eddington & 2,231 & 2.49 & 896 & 54.2 & 485 \\
\hline Edinburg & 94 & 2.23 & 42 & 100 & 42 \\
\hline Enfield & 1,541 & 2.64 & 583 & 98.9 & 576 \\
\hline Etna & 971 & 2.58 & 376 & 100 & 376 \\
\hline Exeter & 1,005 & 2.56 & 392 & 98.9 & 387 \\
\hline Garland & 947 & 2.61 & 362 & 100 & 362 \\
\hline
\end{tabular}


Appendix 1. Demographic data for towns in Maine.-Continued

[Plt, Plantation; UT, Unincorporated Territory; Twp, Township; NA, not available]

\begin{tabular}{|c|c|c|c|c|c|}
\hline Town or county subdivision & $\begin{array}{c}\text { Population' } \\
2008\end{array}$ & $\begin{array}{c}\text { Population } \\
\text { per household }{ }^{2} \text {, } \\
2000\end{array}$ & $\begin{array}{c}\text { Estimated } \\
\text { number of } \\
\text { households }{ }^{3} \text {, } \\
2008\end{array}$ & $\begin{array}{l}\text { Precentage of } \\
\text { self-supplied } \\
\text { households } \\
1990\end{array}$ & $\begin{array}{c}\text { Estimated } \\
\text { number of } \\
\text { self-supplied } \\
\text { households } \\
2008 \\
\text {, }\end{array}$ \\
\hline \multicolumn{6}{|c|}{ Penobscot County-Continued } \\
\hline Glenburn & 4,447 & 2.68 & 1,659 & 97.2 & 1,612 \\
\hline Hermon & 5,314 & 2.66 & 1,995 & 95.5 & 1,905 \\
\hline Holden & 2,988 & 2.45 & 1,218 & 74.5 & 907 \\
\hline Howland & 1,326 & 2.47 & 537 & 18.4 & 98 \\
\hline Hudson & 1,440 & 2.74 & 525 & 100 & 525 \\
\hline Indian Island & 545 & 2.63 & 207 & 5.0 & 10 \\
\hline Lee & 814 & 2.84 & 287 & 100 & 287 \\
\hline Levant & 2,640 & 2.77 & 953 & 98.4 & 937 \\
\hline Lincoln & 5,258 & 2.48 & 2,122 & 43.0 & 912 \\
\hline Lowell & 304 & 2.43 & 125 & 100 & 125 \\
\hline Mattawamkeag & 790 & 2.44 & 323 & 97.1 & 313 \\
\hline Maxfield & 92 & 2.23 & 41 & 100 & 41 \\
\hline Medway & 1,449 & 2.54 & 571 & 91.3 & 521 \\
\hline Milford & 2,980 & 2.50 & 1,192 & 31.8 & 379 \\
\hline Millinocket & 4,902 & 2.27 & 2,162 & 0.9 & 19 \\
\hline Mount Chase & 236 & 2.38 & 99 & 64.1 & 63 \\
\hline Passadumkeag & 431 & 2.56 & 168 & 93.9 & 157 \\
\hline Patten & 1,084 & 2.37 & 456 & 57.9 & 264 \\
\hline Plymouth & 1,317 & 2.68 & 491 & 100 & 491 \\
\hline Prentiss Twp & 205 & 2.48 & 82 & 100 & 82 \\
\hline Seboeis Plt & 39 & 2.41 & 16 & 80.3 & 12 \\
\hline Springfield & 371 & 2.53 & 146 & 100 & 146 \\
\hline Stacyville & 385 & 2.50 & 154 & 99.0 & 152 \\
\hline Stetson & 1,073 & 2.56 & 418 & 100 & 418 \\
\hline Veazie & 1,891 & 2.42 & 782 & 6.8 & 53 \\
\hline Webster Plt & 79 & 3.04 & 26 & 100 & 26 \\
\hline Winn & 393 & 2.47 & 159 & 100 & 159 \\
\hline Woodville & 276 & 2.78 & 99 & 100 & 99 \\
\hline \multicolumn{6}{|c|}{ Piscataquis County } \\
\hline Abbot & 596 & 2.32 & 257 & 97.7 & 251 \\
\hline Atkinson & 312 & 2.45 & 127 & 100 & 127 \\
\hline Beaver Cove & 87 & 1.98 & 43 & 74.2 & 31 \\
\hline Blanchard Twp & 78 & 2.37 & 32 & 98.5 & 31 \\
\hline Bowerbank & 148 & 2.28 & 64 & 100 & 64 \\
\hline
\end{tabular}


Appendix 1. Demographic data for towns in Maine.-Continued

[Plt, Plantation; UT, Unincorporated Territory; Twp, Township; NA, not available]

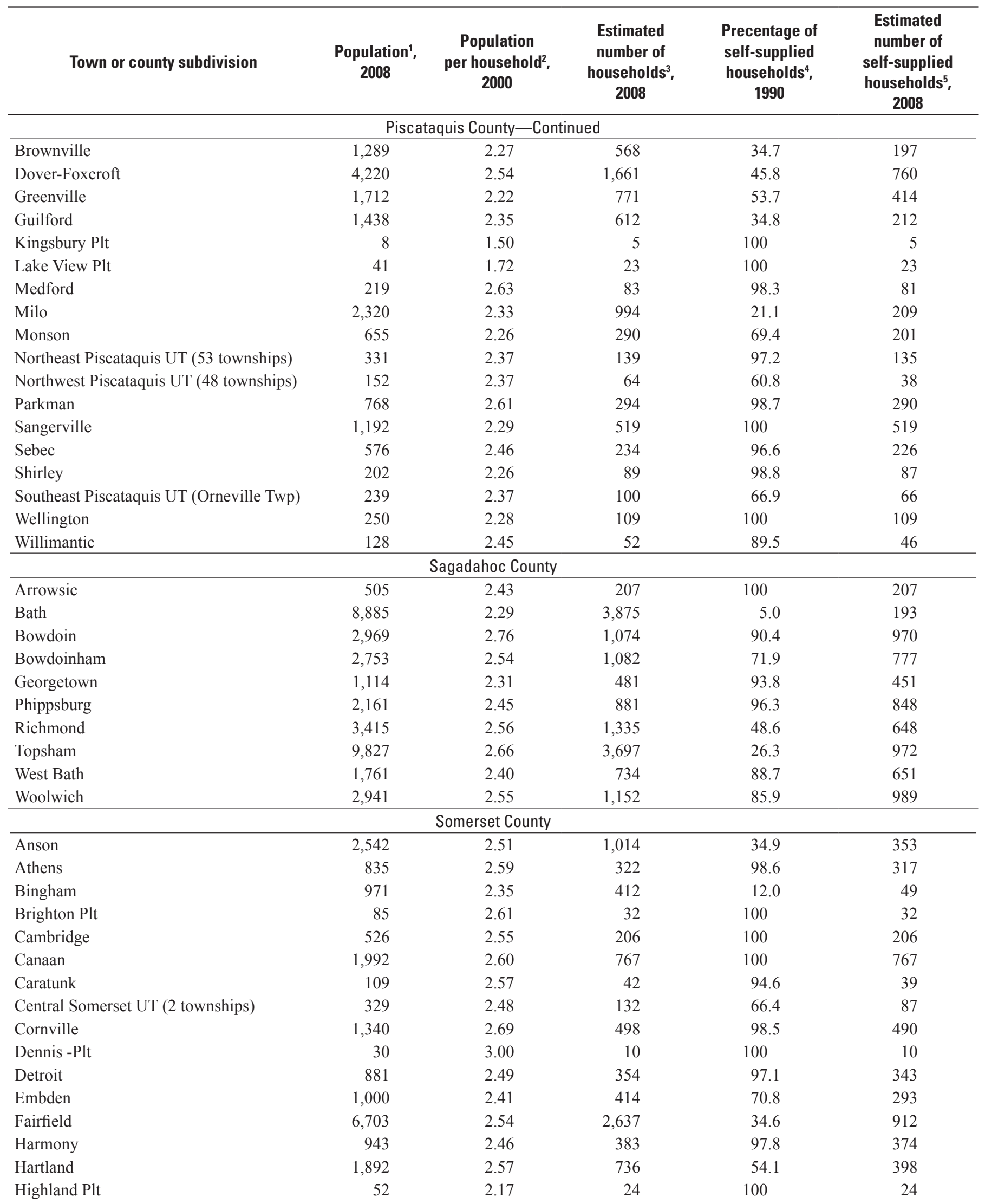


Appendix 1. Demographic data for towns in Maine.-Continued

[Plt, Plantation; UT, Unincorporated Territory; Twp, Township; NA, not available]

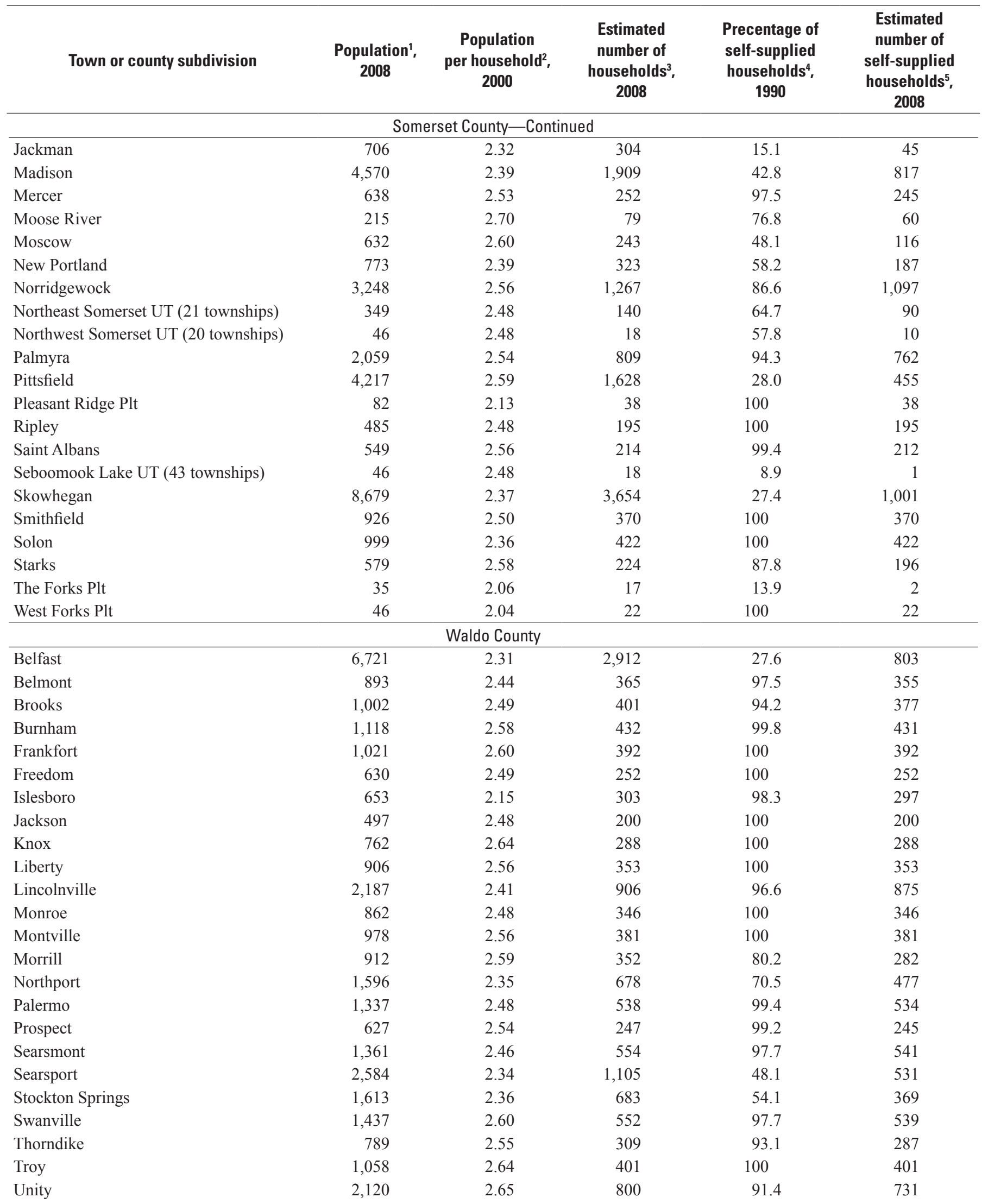


Appendix 1. Demographic data for towns in Maine.-Continued

[Plt, Plantation; UT, Unincorporated Territory; Twp, Township; NA, not available]

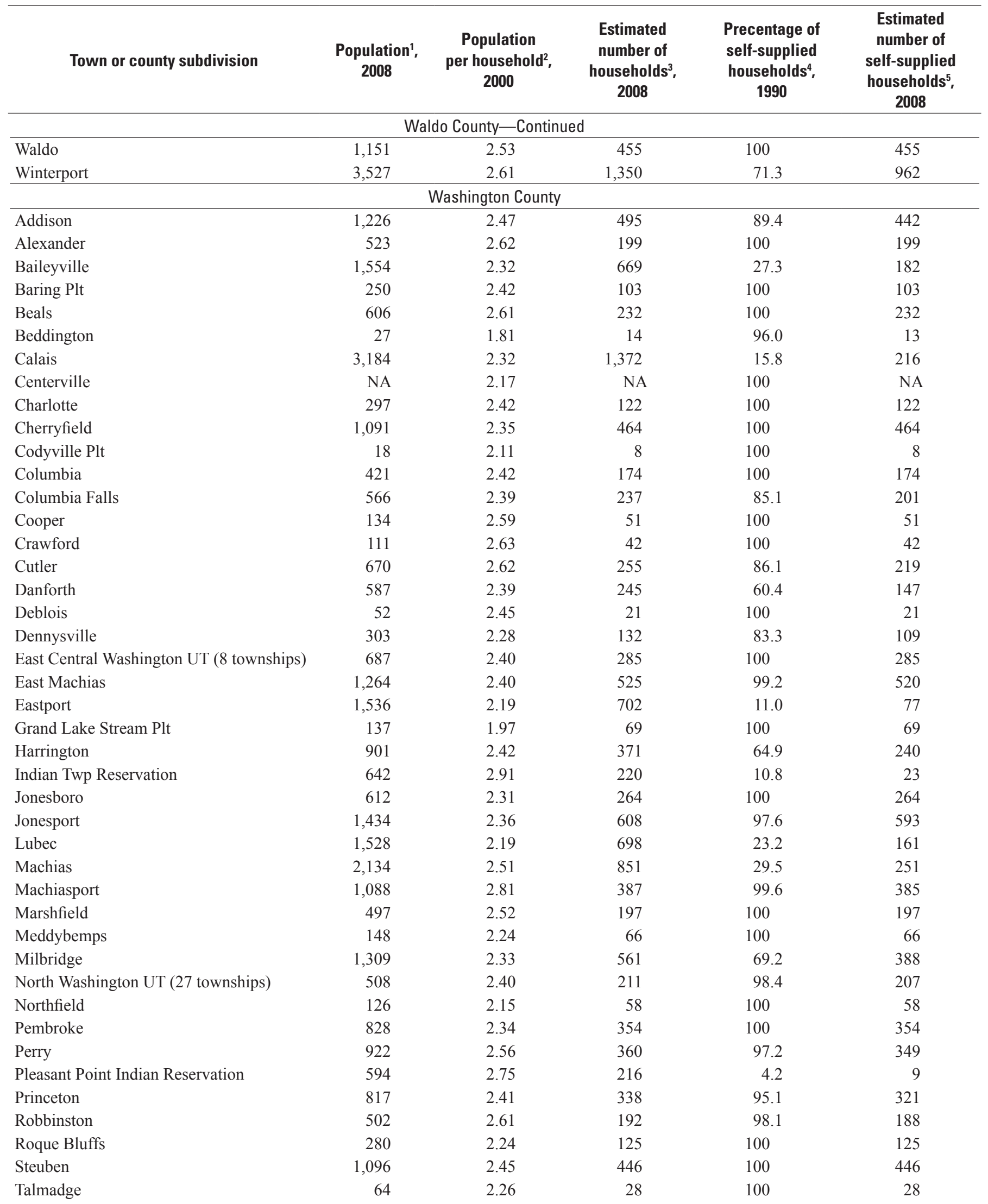


Appendix 1. Demographic data for towns in Maine.-Continued

[Plt, Plantation; UT, Unincorporated Territory; Twp, Township; NA, not available]

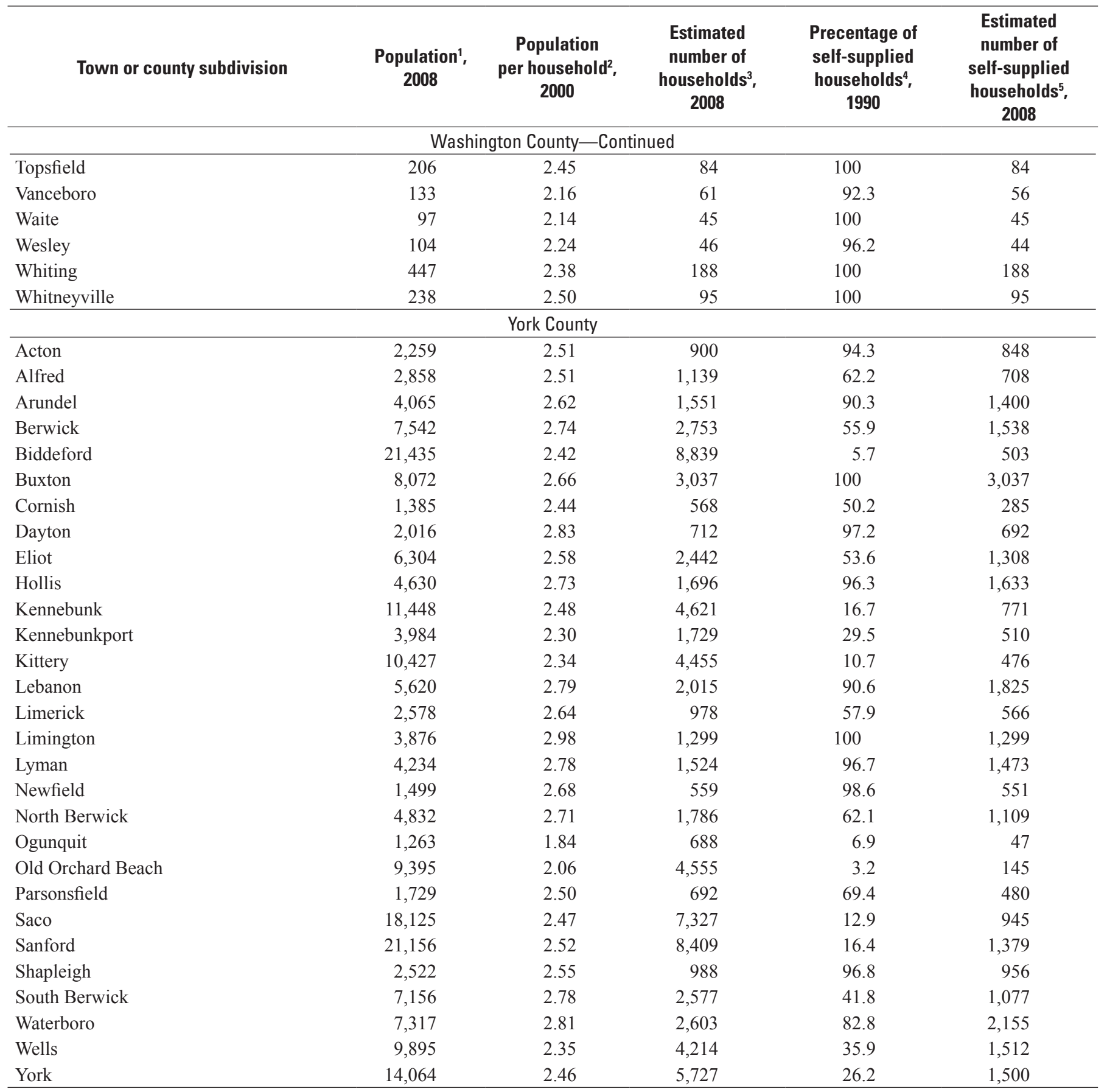

${ }^{1}$ U.S. Census Bureau, 2008, Census Bureau annual estimates of population of Maine towns and counties, April 2000-July 2008 Table 5: Annual estimates of the resident population for Minor Civil Divisions in Maine, listed alphabetically within county: April 1, 2000 to July 1, 2008 (SUB-EST2008-05-23). Source: Population Division, U.S. Census Bureau. Release date: July 1, 2009, accessed November 20, 2009, at http://www.maine.gov/spo/economics/docs/townleveldata/mcdpop2000-08.xls.

${ }^{2}$ U.S. Census Bureau, 2000, Demographic Profiles: 100-percent and sample data, Table DP-1. Profile of general demographic characteristics: 2000. Data accessed from Maine State Planning Office, March 1, 2010, at http://maine.gov/spo/economics/docs/census/prof1_4datame.xls.

${ }^{3}$ Calculated by dividing the population in 2008 by the number of persons per household in 2000.

${ }^{4}$ U.S. Census Bureau, 1990, 1990 Summary tape file 3 (STF-3) sample data, Table DP-5. Housing characteristics: 1990.

${ }^{5}$ Calculated by multiplying the estimated number of households in 2008 by the percentage of self-supplied households in 1990. 
Appendix 2. Numbers of samples and wells with samples, by town, in Maine, and minimum, maximum, and median arsenic concentrations in each town with samples in the Maine Health and Environmental Testing Laboratory database, 2005-09.

[Statistics are calculated on wells, not total number of samples. See text for explanation of the treatment of multiple samples per well; $\mu \mathrm{g} / \mathrm{L}$, micrograms per liter; <, less than; Twp, township; Plt, plantation; UT, unincorporated territory]

\begin{tabular}{|c|c|c|c|c|c|}
\hline Town & $\begin{array}{l}\text { Number of } \\
\text { samples }\end{array}$ & $\begin{array}{c}\text { Number of wells } \\
\text { with samples }\end{array}$ & \multicolumn{3}{|c|}{ Town arsenic concentrations } \\
\hline Auburn & 49 & 37 & $<0.5$ & 190 & 3.2 \\
\hline Durham & 50 & 43 & $<.5$ & 9.0 & $<.5$ \\
\hline Leeds & 41 & 27 & $<.5$ & 130 & 2.1 \\
\hline Lewiston & 22 & 19 & $<.5$ & 94.0 & .6 \\
\hline Lisbon & 41 & 38 & $<.5$ & 16.0 & 1.5 \\
\hline Livermore & 27 & 20 & $<.5$ & 4.3 & $<.5$ \\
\hline Livermore Falls & 15 & 12 & $<.5$ & 12.0 & 1.1 \\
\hline Sabattus & 68 & 62 & $<.5$ & 89.0 & 2.3 \\
\hline Turner & 122 & 95 & $<.5$ & 84.0 & $<.5$ \\
\hline Wales & 16 & 15 & $<.5$ & 130 & 1.5 \\
\hline \multicolumn{6}{|c|}{ Aroostook County } \\
\hline Allagash & 3 & 3 & $<0.5$ & 18.0 & 5.0 \\
\hline Amity & 3 & 3 & $<.5$ & 1.7 & .7 \\
\hline Ashland & 4 & 4 & $<.5$ & $<.5$ & $<.5$ \\
\hline Benedicta Twp & 3 & 2 & $<.5$ & $<.5$ & $<.5$ \\
\hline Connor Twp & 2 & 2 & $<.5$ & $<.5$ & $<.5$ \\
\hline Crystal & 5 & 5 & $<.5$ & .8 & $<.5$ \\
\hline Cyr Plt & 2 & 2 & $<.5$ & $<.5$ & $<.5$ \\
\hline Dyer Brook & 1 & 1 & 22.0 & 22.0 & 22.0 \\
\hline Eagle Lake & 10 & 8 & $<.5$ & 6.6 & $<.5$ \\
\hline Easton & 12 & 12 & $<.5$ & 3.6 & $<.5$ \\
\hline Fort Fairfield & 16 & 11 & $<.5$ & 10.0 & $<.5$ \\
\hline Fort Kent & 19 & 17 & $<.5$ & 5.1 & .8 \\
\hline Frenchville & 4 & 3 & $<.5$ & 6.9 & .7 \\
\hline Garfield Plt & 2 & 1 & $<.5$ & $<.5$ & $<.5$ \\
\hline Grand Isle & 2 & 2 & $<.5$ & $<.5$ & $<.5$ \\
\hline Hamlin & 6 & 6 & $<.5$ & $<.5$ & $<.5$ \\
\hline Hammond & 1 & 1 & 9.1 & 9.1 & 9.1 \\
\hline Haynesville & 2 & 1 & 1.1 & 1.1 & 1.1 \\
\hline
\end{tabular}


Appendix 2. Numbers of samples and wells with samples, by town, in Maine, and minimum, maximum, and median arsenic concentrations in each town with samples in the Maine Health and Environmental Testing Laboratory database, 2005-09._-Continued

[Statistics are calculated on wells, not total number of samples. See text for explanation of the treatment of multiple samples per well; $\mu \mathrm{g} / \mathrm{L}$, micrograms per liter; <, less than; Twp, township; Plt, plantation; UT, unincorporated territory]

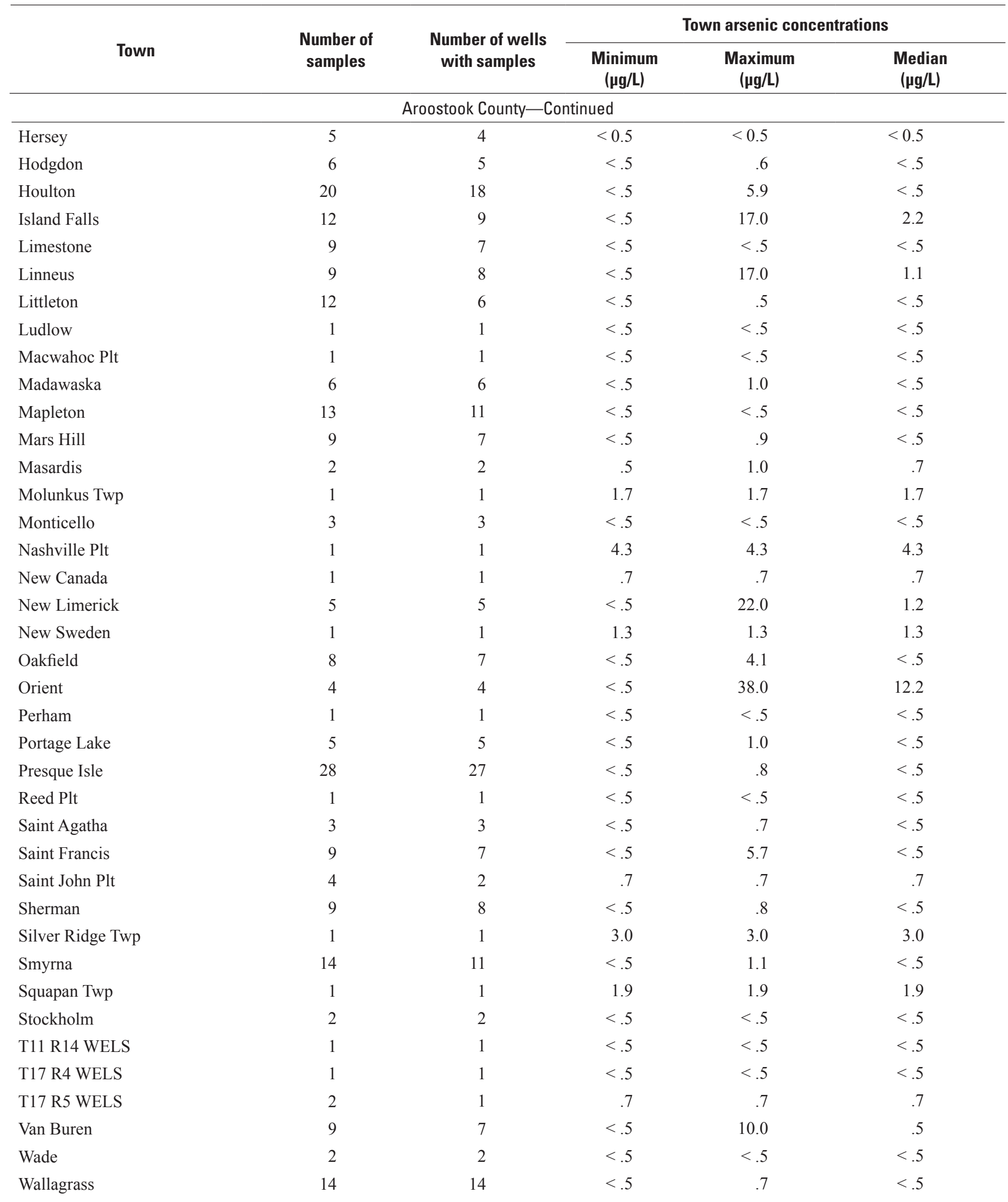


Appendix 2. Numbers of samples and wells with samples, by town, in Maine, and minimum, maximum, and median arsenic concentrations in each town with samples in the Maine Health and Environmental Testing Laboratory database, 2005-09.-Continued

[Statistics are calculated on wells, not total number of samples. See text for explanation of the treatment of multiple samples per well; $\mu \mathrm{g} / \mathrm{L}$, micrograms per liter; <, less than; Twp, township; Plt, plantation; UT, unincorporated territory]

\begin{tabular}{|c|c|c|c|c|c|}
\hline Town & $\begin{array}{l}\text { Number of } \\
\text { samples }\end{array}$ & $\begin{array}{l}\text { Number of wells } \\
\text { with samples }\end{array}$ & \multicolumn{3}{|c|}{ Town arsenic concentrations } \\
\hline Washburn & 7 & 5 & $<0.5$ & 1.4 & $<0.5$ \\
\hline Westfield & 1 & 1 & $<.5$ & $<.5$ & $<.5$ \\
\hline Weston & 18 & 15 & $<.5$ & 70.0 & 5.7 \\
\hline Winterville Plt & 3 & 2 & $<.5$ & $<.5$ & $<.5$ \\
\hline Woodland & 9 & 7 & $<.5$ & 2.7 & $<.5$ \\
\hline \multicolumn{6}{|c|}{ Cumberland County } \\
\hline Cape Elizabeth & 1 & 1 & $<.5$ & $<.5$ & $<.5$ \\
\hline Casco & 52 & 36 & $<.5$ & 7.3 & $<.5$ \\
\hline Cumberland & 91 & 84 & $<.5$ & 87.0 & 1.0 \\
\hline Falmouth & 62 & 53 & $<.5$ & 22.0 & 2.3 \\
\hline Freeport & 65 & 61 & $<.5$ & 110 & .7 \\
\hline Gorham & 287 & 218 & $<.5$ & 280 & 14.0 \\
\hline Gray & 141 & 111 & $<.5$ & 260 & 3.9 \\
\hline Harpswell & 99 & 87 & $<.5$ & 16.0 & $<.5$ \\
\hline Harrison & 39 & 29 & $<.5$ & 2.4 & $<.5$ \\
\hline Raymond & 63 & 52 & $<.5$ & 13.0 & $<.5$ \\
\hline Scarborough & 84 & 61 & $<.5$ & 220 & 8.6 \\
\hline Sebago & 29 & 26 & $<.5$ & 5.1 & $<.5$ \\
\hline South Portland & 3 & 3 & $<.5$ & .6 & $<.5$ \\
\hline Standish & 149 & 120 & $<.5$ & 420 & 2.5 \\
\hline Westbrook & 7 & 6 & $<.5$ & 42.0 & 3.6 \\
\hline Windham & 92 & 81 & $<.5$ & 150 & 2.3 \\
\hline Yarmouth & 21 & 17 & $<.5$ & 39.0 & 2.9 \\
\hline \multicolumn{6}{|c|}{ Franklin County } \\
\hline Avon & 6 & 6 & $<0.5$ & 1.2 & 0.5 \\
\hline Carrabassett Valley & 26 & 20 & $<.5$ & 36.0 & 2.4 \\
\hline Carthage & 7 & 6 & $<.5$ & 1.3 & $<.5$ \\
\hline Chain of Ponds Twp & 1 & 1 & $<.5$ & $<.5$ & $<.5$ \\
\hline Chesterville & 20 & 16 & $<.5$ & 10.0 & 1.3 \\
\hline
\end{tabular}


Appendix 2. Numbers of samples and wells with samples, by town, in Maine, and minimum, maximum, and median arsenic concentrations in each town with samples in the Maine Health and Environmental Testing Laboratory database, 2005-09.-Continued

[Statistics are calculated on wells, not total number of samples. See text for explanation of the treatment of multiple samples per well; $\mu \mathrm{g} / \mathrm{L}$, micrograms per liter; <, less than; Twp, township; Plt, plantation; UT, unincorporated territory]

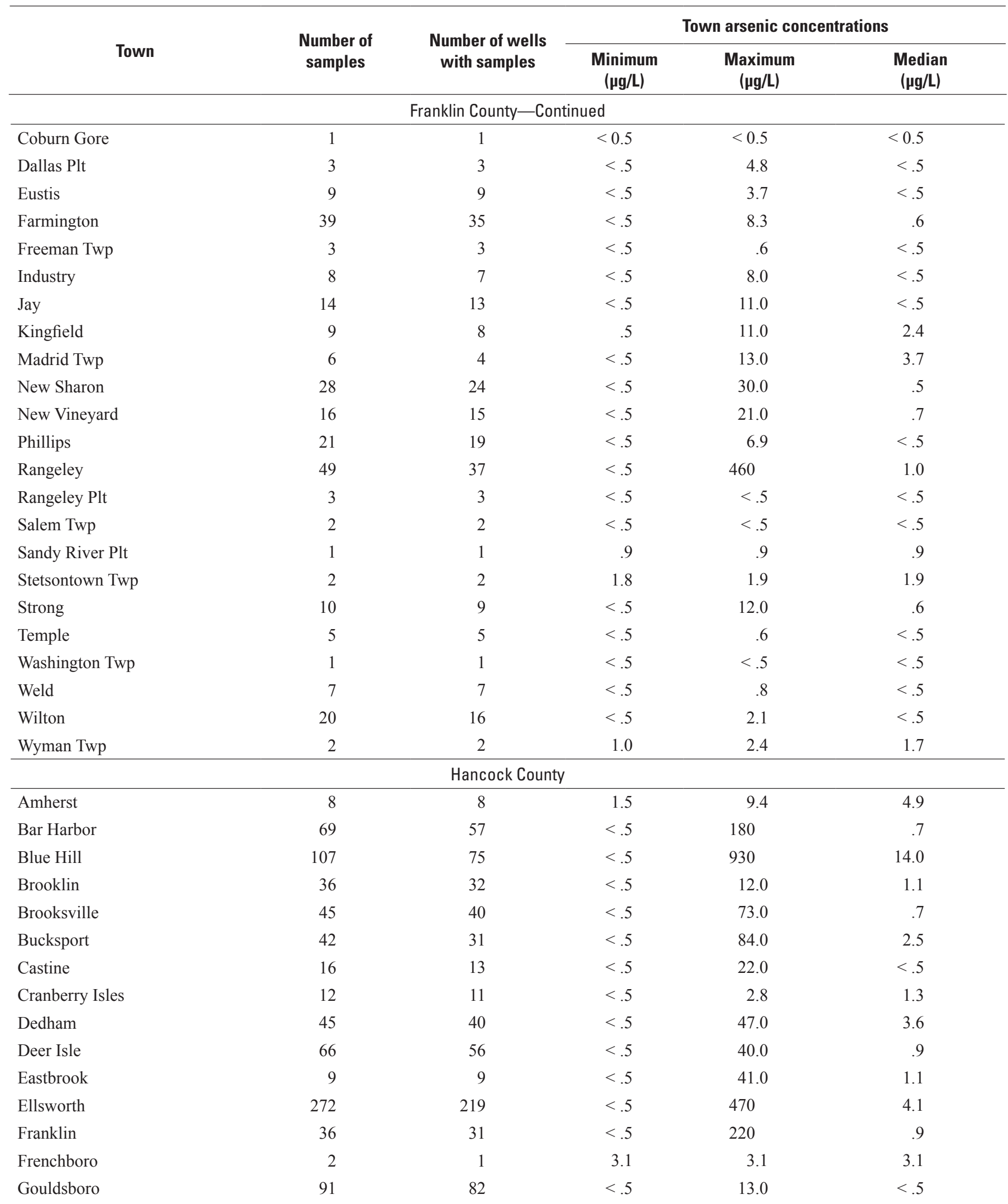


Appendix 2. Numbers of samples and wells with samples, by town, in Maine, and minimum, maximum, and median arsenic concentrations in each town with samples in the Maine Health and Environmental Testing Laboratory database, 2005-09.-Continued

[Statistics are calculated on wells, not total number of samples. See text for explanation of the treatment of multiple samples per well; $\mu \mathrm{g} / \mathrm{L}$, micrograms per liter; <, less than; Twp, township; Plt, plantation; UT, unincorporated territory]

\begin{tabular}{|c|c|c|c|c|c|}
\hline Town & $\begin{array}{l}\text { Number of } \\
\text { samples }\end{array}$ & $\begin{array}{c}\text { Number of wells } \\
\text { with samples }\end{array}$ & \multicolumn{3}{|c|}{ Town arsenic concentrations } \\
\hline Great Pond & 1 & 1 & 0.9 & 0.9 & 0.9 \\
\hline Hancock & 57 & 45 & $<.5$ & 76.0 & 2.0 \\
\hline Mariaville & 20 & 14 & $<.5$ & 65.0 & 7.0 \\
\hline Mount Desert & 39 & 35 & $<.5$ & 4.0 & $<.5$ \\
\hline Mount Desert & 1 & 1 & $<.5$ & $<.5$ & $<.5$ \\
\hline Orland & 46 & 40 & $<.5$ & 160 & 5.2 \\
\hline Osborn & 3 & 3 & 6.5 & 30.0 & 15.0 \\
\hline Sorrento & 11 & 6 & $<.5$ & 8.4 & 1.2 \\
\hline Southwest Harbor & 8 & 8 & $<.5$ & 1.4 & $<.5$ \\
\hline Stonington & 35 & 21 & $<.5$ & 3.8 & $<.5$ \\
\hline Sullivan & 110 & 94 & $<.5$ & 130 & 1.5 \\
\hline Surry & 141 & 120 & $<.5$ & 660 & 11.0 \\
\hline Swans Island & 22 & 18 & $<.5$ & 5.0 & $<.5$ \\
\hline T10 SD & 1 & 1 & $<.5$ & $<.5$ & $<.5$ \\
\hline T28 MD & 1 & 1 & 27.0 & 27.0 & 27.0 \\
\hline Winter Harbor & 11 & 9 & $<.5$ & $<.5$ & $<.5$ \\
\hline \multicolumn{6}{|c|}{ Kennebec County } \\
\hline Albion & 33 & 24 & $<0.5$ & 33.0 & 2.4 \\
\hline Augusta & 183 & 151 & $<.5$ & 120 & 2.6 \\
\hline Belgrade & 126 & 95 & $<.5$ & 220 & 6.1 \\
\hline Benton & 20 & 16 & $<.5$ & 11.0 & 1.1 \\
\hline Chelsea & 84 & 75 & $<.5$ & 220 & 1.2 \\
\hline China & 104 & 80 & $<.5$ & 65.0 & 1.8 \\
\hline Clinton & 22 & 14 & $<.5$ & 81.0 & 2.4 \\
\hline Farmingdale & 41 & 31 & $<.5$ & 60.0 & 3.2 \\
\hline Fayette & 57 & 44 & $<.5$ & 51.0 & 2.5 \\
\hline Gardiner & 31 & 28 & $<.5$ & 67.0 & $<.5$ \\
\hline Hallowell & 18 & 15 & .7 & 120 & 10.0 \\
\hline Litchfield & 156 & 110 & $<.5$ & 400 & 5.5 \\
\hline
\end{tabular}


Appendix 2. Numbers of samples and wells with samples, by town, in Maine, and minimum, maximum, and median arsenic concentrations in each town with samples in the Maine Health and Environmental Testing Laboratory database, 2005-09.-Continued

[Statistics are calculated on wells, not total number of samples. See text for explanation of the treatment of multiple samples per well; $\mu \mathrm{g} / \mathrm{L}$, micrograms per liter; <, less than; Twp, township; Plt, plantation; UT, unincorporated territory]

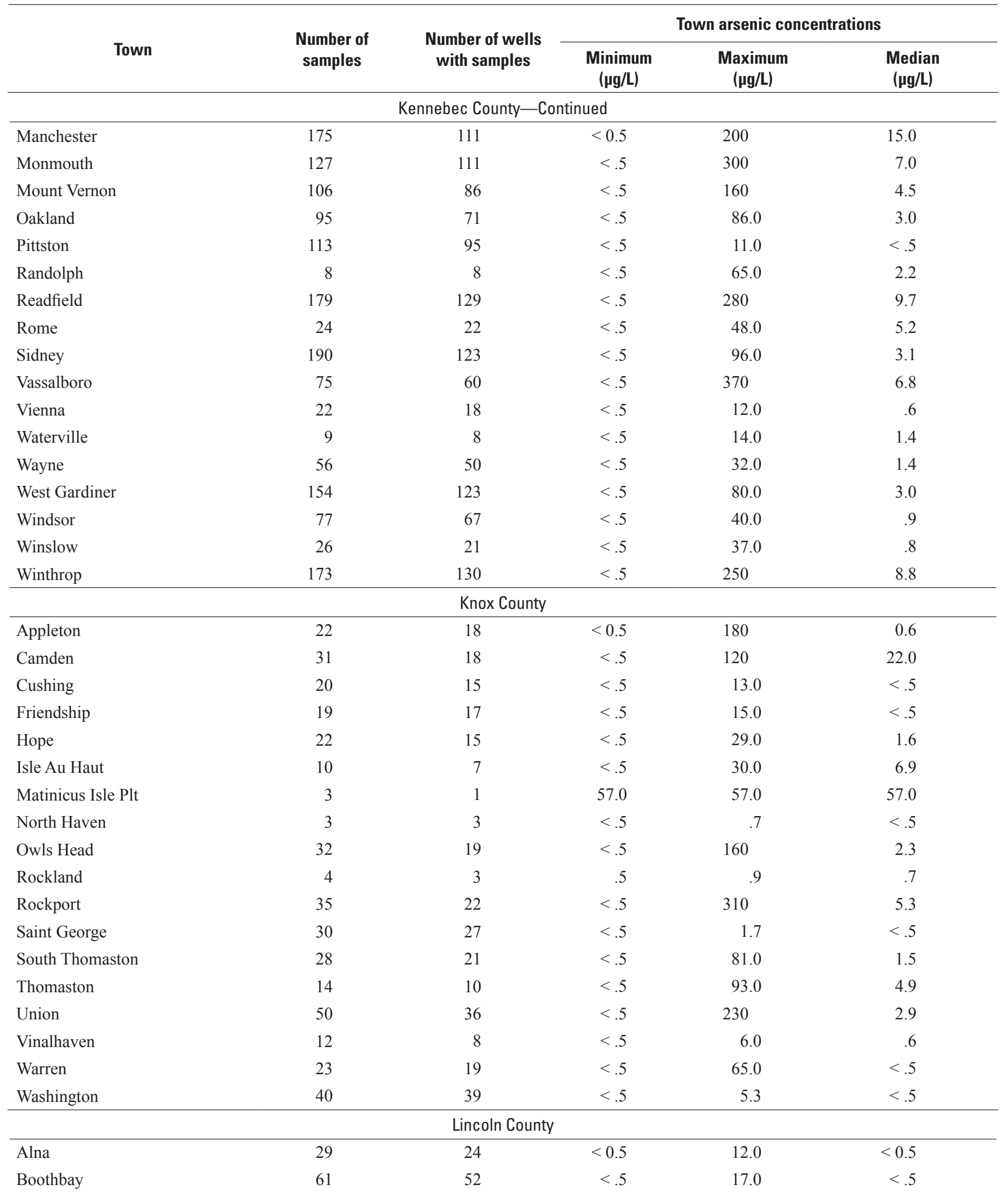


Appendix 2. Numbers of samples and wells with samples, by town, in Maine, and minimum, maximum, and median arsenic concentrations in each town with samples in the Maine Health and Environmental Testing Laboratory database, 2005-09._-Continued

[Statistics are calculated on wells, not total number of samples. See text for explanation of the treatment of multiple samples per well; $\mu \mathrm{g} / \mathrm{L}$, micrograms per liter; <, less than; Twp, township; Plt, plantation; UT, unincorporated territory]

\begin{tabular}{|c|c|c|c|c|c|}
\hline Town & $\begin{array}{l}\text { Number of } \\
\text { samples }\end{array}$ & $\begin{array}{c}\text { Number of wells } \\
\text { with samples }\end{array}$ & \multicolumn{3}{|c|}{ Town arsenic concentrations } \\
\hline Boothbay Harbor & 8 & 7 & $<0.5$ & $<0.5$ & $<0.5$ \\
\hline Bremen & 19 & 15 & $<.5$ & 6.1 & 6 \\
\hline Bristol & 52 & 48 & $<.5$ & 21.0 & $<.5$ \\
\hline Damariscotta & 24 & 23 & $<.5$ & 5.4 & $<.5$ \\
\hline Dresden & 61 & 57 & $<.5$ & 22.0 & 6 \\
\hline Edgecomb & 36 & 35 & $<.5$ & 4.8 & $<.5$ \\
\hline Jefferson & 91 & 76 & $<.5$ & 53.0 & 1.0 \\
\hline Monhegan Island Plt & 1 & 1 & $<.5$ & $<.5$ & $<.5$ \\
\hline Newcastle & 29 & 29 & $<.5$ & 4.0 & $<.5$ \\
\hline Nobleboro & 35 & 30 & $<.5$ & 11.0 & $<.5$ \\
\hline Somerville & 13 & 11 & $<.5$ & 7.3 & $<.5$ \\
\hline South Bristol & 38 & 32 & $<.5$ & 4.6 & $<.5$ \\
\hline Southport & 10 & 10 & $<.5$ & 2.6 & $<.5$ \\
\hline Waldoboro & 37 & 32 & $<.5$ & 19.0 & 1.2 \\
\hline Westport & 12 & 11 & $<.5$ & 1.1 & $<.5$ \\
\hline Whitefield & 117 & 91 & $<.5$ & 84.0 & $<.5$ \\
\hline Wiscasset & 48 & 38 & $<.5$ & 5.0 & $<.5$ \\
\hline \multicolumn{6}{|c|}{ Oxford County } \\
\hline Albany Twp & 2 & 2 & $<0.5$ & $<0.5$ & $<0.5$ \\
\hline Andover & 13 & 10 & $<.5$ & 1.1 & $<.5$ \\
\hline Bethel & 19 & 19 & $<.5$ & 2.5 & $<.5$ \\
\hline Brownfield & 5 & 5 & $<.5$ & 14.0 & 1.2 \\
\hline Buckfield & 47 & 36 & $<.5$ & 330 & 3.2 \\
\hline Byron & 3 & 3 & $<.5$ & $<.5$ & $<.5$ \\
\hline Canton & 12 & 10 & $<.5$ & 3.7 & $<.5$ \\
\hline Denmark & 10 & 10 & $<.5$ & .7 & $<.5$ \\
\hline Dixfield & 24 & 23 & $<.5$ & 1.4 & $<.5$ \\
\hline Fryeburg & 19 & 16 & $<.5$ & .7 & $<.5$ \\
\hline Gilead & 9 & 7 & $<.5$ & $<.5$ & $<.5$ \\
\hline Greenwood & 10 & 10 & $<.5$ & 15.0 & $<.5$ \\
\hline Hanover & 1 & 1 & $<.5$ & $<.5$ & $<.5$ \\
\hline Hartford & 11 & 11 & $<.5$ & 9.3 & .7 \\
\hline Hebron & 8 & 7 & .5 & 58.0 & 2.0 \\
\hline Hiram & 12 & 11 & $<.5$ & 25.0 & $<.5$ \\
\hline Lincoln Plt & 2 & 1 & $<.5$ & $<.5$ & $<.5$ \\
\hline Lovell & 18 & 12 & $<.5$ & 2.8 & $<.5$ \\
\hline Lower Cupsuptic Twp & 1 & 1 & .5 & .5 & .5 \\
\hline Mason Twp & 1 & 1 & $<.5$ & $<.5$ & $<.5$ \\
\hline Mexico & 16 & 14 & $<.5$ & .7 & $<.5$ \\
\hline
\end{tabular}


Appendix 2. Numbers of samples and wells with samples, by town, in Maine, and minimum, maximum, and median arsenic concentrations in each town with samples in the Maine Health and Environmental Testing Laboratory database, 2005-09._-Continued

[Statistics are calculated on wells, not total number of samples. See text for explanation of the treatment of multiple samples per well; $\mu \mathrm{g} / \mathrm{L}, \mathrm{micrograms}$ per liter; <, less than; Twp, township; Plt, plantation; UT, unincorporated territory]

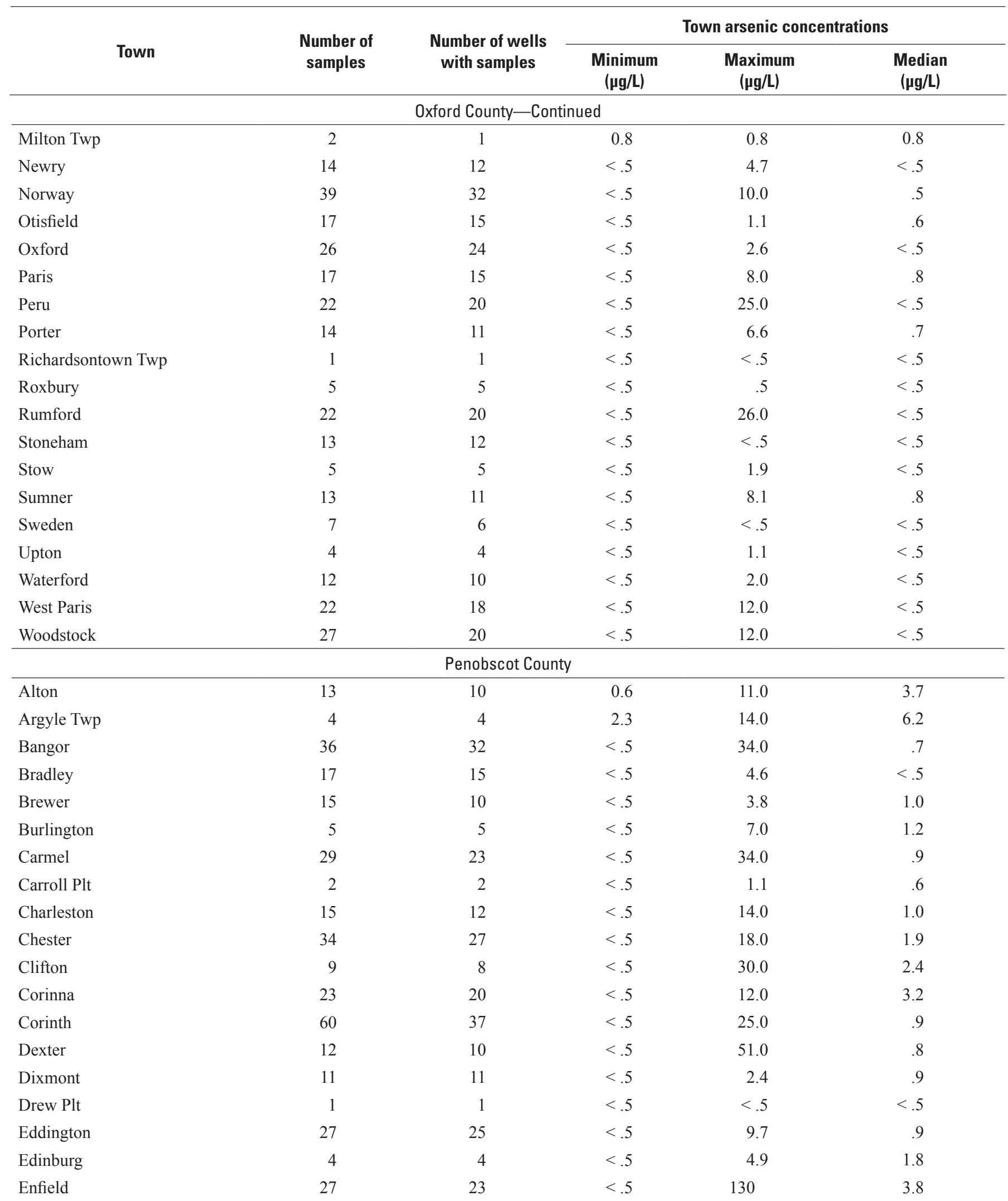


Appendix 2. Numbers of samples and wells with samples, by town, in Maine, and minimum, maximum, and median arsenic concentrations in each town with samples in the Maine Health and Environmental Testing Laboratory database, 2005-09.-Continued

[Statistics are calculated on wells, not total number of samples. See text for explanation of the treatment of multiple samples per well; $\mu \mathrm{g} / \mathrm{L}$, micrograms per liter; <, less than; Twp, township; Plt, plantation; UT, unincorporated territory]

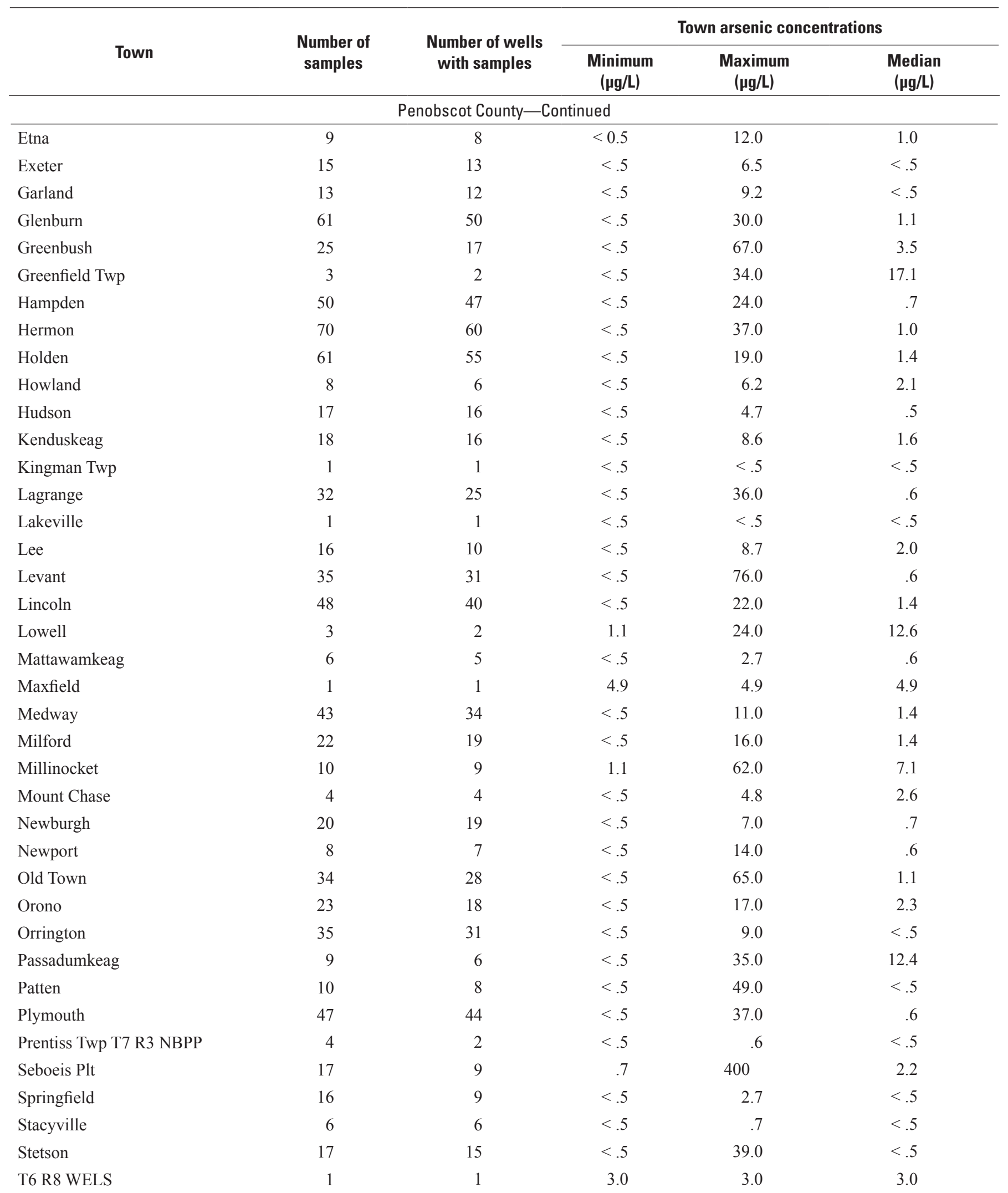


Appendix 2. Numbers of samples and wells with samples, by town, in Maine, and minimum, maximum, and median arsenic concentrations in each town with samples in the Maine Health and Environmental Testing Laboratory database, 2005-09.-Continued

[Statistics are calculated on wells, not total number of samples. See text for explanation of the treatment of multiple samples per well; $\mu \mathrm{g} / \mathrm{L}$, micrograms per liter; <, less than; Twp, township; Plt, plantation; UT, unincorporated territory]

\begin{tabular}{|c|c|c|c|c|c|}
\hline Town & $\begin{array}{l}\text { Number of } \\
\text { samples }\end{array}$ & $\begin{array}{l}\text { Number of wells } \\
\text { with samples }\end{array}$ & \multicolumn{3}{|c|}{ Town arsenic concentrations } \\
\hline \multicolumn{6}{|c|}{ Penobscot County-Continued } \\
\hline Veazie & 3 & 3 & $<0.5$ & 2.7 & $<0.5$ \\
\hline Winn & 6 & 5 & $<.5$ & 5.7 & 2.2 \\
\hline \multicolumn{6}{|c|}{ Piscataquis County } \\
\hline Abbot & 4 & 4 & 2.3 & 12.0 & 4.4 \\
\hline Atkinson & 5 & 5 & $<.5$ & 290 & .5 \\
\hline Barnard Twp & 1 & 1 & $<.5$ & $<.5$ & $<.5$ \\
\hline Bowerbank & 3 & 3 & $<.5$ & 17.0 & 3.6 \\
\hline Brownville & 22 & 19 & $<.5$ & 69.0 & 5.6 \\
\hline Dover-Foxcroft & 39 & 34 & $<.5$ & 38.0 & .9 \\
\hline Elliottsville Twp & 5 & 4 & $<.5$ & 90.0 & $<.5$ \\
\hline Frenchtown Twp & 8 & 4 & .5 & 35.0 & 3.8 \\
\hline Greenville & 15 & 14 & $<.5$ & 26.0 & 2.0 \\
\hline Guilford & 12 & 6 & $<.5$ & 43.0 & .8 \\
\hline Harfords Point Twp & 1 & 1 & 6.0 & 6.0 & 6.0 \\
\hline Kingsbury Plt & 1 & 1 & 12.0 & 12.0 & 12.0 \\
\hline Parkman & 9 & 8 & $<.5$ & 19.0 & 1.4 \\
\hline Sangerville & 8 & 7 & $<.5$ & 3.0 & $<.5$ \\
\hline Sebec & 5 & 4 & $<.5$ & 3.5 & .5 \\
\hline Shirley & 3 & 2 & $<.5$ & 11.0 & 5.6 \\
\hline T1 R9 WELS & 2 & 2 & $<.5$ & 8.9 & 4.5 \\
\hline T2 R10 WELS & 1 & 1 & $<.5$ & $<.5$ & $<.5$ \\
\hline T2 R13 WELS & 1 & 1 & 1.0 & 1.0 & 1.0 \\
\hline T7 R14 WELS & 1 & 1 & 2.2 & 2.2 & 2.2 \\
\hline T9 R9 WELS & 1 & 1 & 4.0 & 4.0 & 4.0 \\
\hline Williamsburg Twp & 1 & 1 & $<.5$ & $<.5$ & $<.5$ \\
\hline Willimantic & 5 & 4 & 2.8 & 33.0 & 16.9 \\
\hline \multicolumn{6}{|c|}{ Sagadahoc County } \\
\hline Arrowsic & 22 & 20 & $<0.5$ & 1.4 & $<0.5$ \\
\hline Bath & 0 & 19 & $<.5$ & 27.0 & 1.7 \\
\hline
\end{tabular}


Appendix 2. Numbers of samples and wells with samples, by town, in Maine, and minimum, maximum, and median arsenic concentrations in each town with samples in the Maine Health and Environmental Testing Laboratory database, 2005-09.-Continued

[Statistics are calculated on wells, not total number of samples. See text for explanation of the treatment of multiple samples per well; $\mu \mathrm{g} / \mathrm{L}$, micrograms per liter; <, less than; Twp, township; Plt, plantation; UT, unincorporated territory]

\begin{tabular}{|c|c|c|c|c|c|}
\hline Town & $\begin{array}{l}\text { Number of } \\
\text { samples }\end{array}$ & $\begin{array}{l}\text { Number of wells } \\
\text { with samples }\end{array}$ & \multicolumn{3}{|c|}{ Town arsenic concentrations } \\
\hline \multicolumn{6}{|c|}{ Sagadahoc County-Continued } \\
\hline Bowdoin & 45 & 39 & $<0.5$ & 52.0 & 0.5 \\
\hline Bowdoinham & 39 & 37 & $<.5$ & 18.0 & $<.5$ \\
\hline Phippsburg & 78 & 69 & $<.5$ & 46.0 & .7 \\
\hline Richmond & 55 & 47 & $<.5$ & 7.9 & $<.5$ \\
\hline Topsham & 43 & 35 & $<.5$ & 20.0 & .7 \\
\hline West Bath & 31 & 26 & $<.5$ & 14.0 & $<.5$ \\
\hline Athens & 12 & 11 & $<.5$ & 42.0 & 3.0 \\
\hline Attean Twp & 1 & 1 & $<.5$ & $<.5$ & $<.5$ \\
\hline Bingham & 6 & 4 & .7 & 3.5 & 2.1 \\
\hline Brighton Plt & 2 & 1 & .8 & .8 & .8 \\
\hline Cambridge & 5 & 5 & $<.5$ & 2.7 & 1.6 \\
\hline Canaan & 48 & 44 & $<.5$ & 41.0 & 1.5 \\
\hline Caratunk & 2 & 2 & 2.9 & 12.0 & 7.5 \\
\hline Carrying Place Twp & 1 & 1 & $<.5$ & $<.5$ & $<.5$ \\
\hline Cornville & 12 & 12 & $<.5$ & 27.0 & 3.4 \\
\hline Highland Plt & 1 & 1 & .7 & .7 & .7 \\
\hline Jackman & 17 & 13 & $<.5$ & 27.0 & .8 \\
\hline Lexington Twp & 1 & 1 & 3.6 & 3.6 & 3.6 \\
\hline Long Pond Twp & 3 & 3 & 1.1 & 11.0 & 1.5 \\
\hline Madison & 75 & 65 & $<.5$ & 44.0 & .9 \\
\hline Mercer & 8 & 7 & $<.5$ & 18.0 & $<.5$ \\
\hline Moose River & 3 & 3 & $<.5$ & 21.0 & $<.5$ \\
\hline Moscow & 4 & 4 & $<.5$ & 3.2 & 1.0 \\
\hline New Portland & 20 & 18 & $<.5$ & 36.0 & 5.5 \\
\hline Norridgewock & 21 & 19 & $<.5$ & 30.0 & 4.5 \\
\hline Palmyra & 25 & 20 & $<.5$ & 14.0 & 1.2 \\
\hline Pittsfield & 16 & 12 & $<.5$ & 8.3 & 1.9 \\
\hline Pleasant Ridge Plt & 3 & 2 & $<.5$ & .9 & .5 \\
\hline Rockwood Strip T1 R1 NBKP & 13 & 12 & $<.5$ & 19.0 & 2.1 \\
\hline
\end{tabular}


Appendix 2. Numbers of samples and wells with samples, by town, in Maine, and minimum, maximum, and median arsenic concentrations in each town with samples in the Maine Health and Environmental Testing Laboratory database, 2005-09.-Continued

[Statistics are calculated on wells, not total number of samples. See text for explanation of the treatment of multiple samples per well; $\mu \mathrm{g} / \mathrm{L}$, micrograms per liter; <, less than; Twp, township; Plt, plantation; UT, unincorporated territory]

\begin{tabular}{|c|c|c|c|c|c|}
\hline Town & $\begin{array}{l}\text { Number of } \\
\text { samples }\end{array}$ & $\begin{array}{c}\text { Number of wells } \\
\text { with samples }\end{array}$ & \multicolumn{3}{|c|}{ Town arsenic concentrations } \\
\hline Saint Albans & 13 & 11 & $<0.5$ & 20.0 & 1.1 \\
\hline Skowhegan & 50 & 34 & $<.5$ & 120 & 3.9 \\
\hline Solon & 17 & 14 & $<.5$ & 33.0 & 1.5 \\
\hline Starks & 3 & 2 & 5.5 & 39.0 & 22.3 \\
\hline The Forks Plt & 2 & 2 & $<.5$ & 2.2 & 1.2 \\
\hline Tomhegan Twp & 3 & 2 & 1.9 & 3.0 & 2.5 \\
\hline Upper Enchanted Twp & 1 & 1 & 2.1 & 2.1 & 2.1 \\
\hline Belfast & 53 & 42 & $<0.5$ & 51.0 & 1.9 \\
\hline Belmont & 11 & 11 & $<.5$ & 16.0 & 3.5 \\
\hline Brooks & 43 & 36 & $<.5$ & 53.0 & $<.5$ \\
\hline Burnham & 8 & 8 & $<.5$ & 12.0 & 1.0 \\
\hline Frankfort & 11 & 9 & $<.5$ & 11.0 & $<.5$ \\
\hline Freedom & 7 & 6 & $<.5$ & .7 & $<.5$ \\
\hline Islesboro & 10 & 7 & .7 & 17.0 & 4.0 \\
\hline Jackson & 12 & 12 & $<.5$ & 7.1 & $<.5$ \\
\hline Knox & 22 & 16 & $<.5$ & 6.2 & $<.5$ \\
\hline Palermo & 35 & 28 & $<.5$ & 13.0 & $<.5$ \\
\hline Prospect & 36 & 26 & $<.5$ & 16.0 & 1.3 \\
\hline Searsmont & 19 & 17 & $<.5$ & 31.0 & .7 \\
\hline Searsport & 19 & 15 & $<.5$ & 38.0 & .5 \\
\hline Stockton Springs & 28 & 23 & $<.5$ & 24.0 & 1.0 \\
\hline Swanville & 25 & 19 & $<.5$ & 52.0 & 2.3 \\
\hline Thorndike & 14 & 13 & $<.5$ & 12.0 & .7 \\
\hline Troy & 3 & 2 & $<.5$ & .6 & $<.5$ \\
\hline Unity & 33 & 26 & $<.5$ & 110 & 1.4 \\
\hline Waldo & 18 & 14 & $<.5$ & 16.0 & .5 \\
\hline Winterport & 47 & 41 & $<.5$ & 20.0 & $<.5$ \\
\hline \multicolumn{6}{|c|}{ Washington County } \\
\hline Addison & 22 & 21 & $<0.5$ & 30.0 & 1.6 \\
\hline Alexander & 7 & 5 & $<.5$ & 31.0 & 1.5 \\
\hline
\end{tabular}


Appendix 2. Numbers of samples and wells with samples, by town, in Maine, and minimum, maximum, and median arsenic concentrations in each town with samples in the Maine Health and Environmental Testing Laboratory database, 2005-09.-Continued

[Statistics are calculated on wells, not total number of samples. See text for explanation of the treatment of multiple samples per well; $\mu \mathrm{g} / \mathrm{L}$, micrograms per liter; <, less than; Twp, township; Plt, plantation; UT, unincorporated territory]

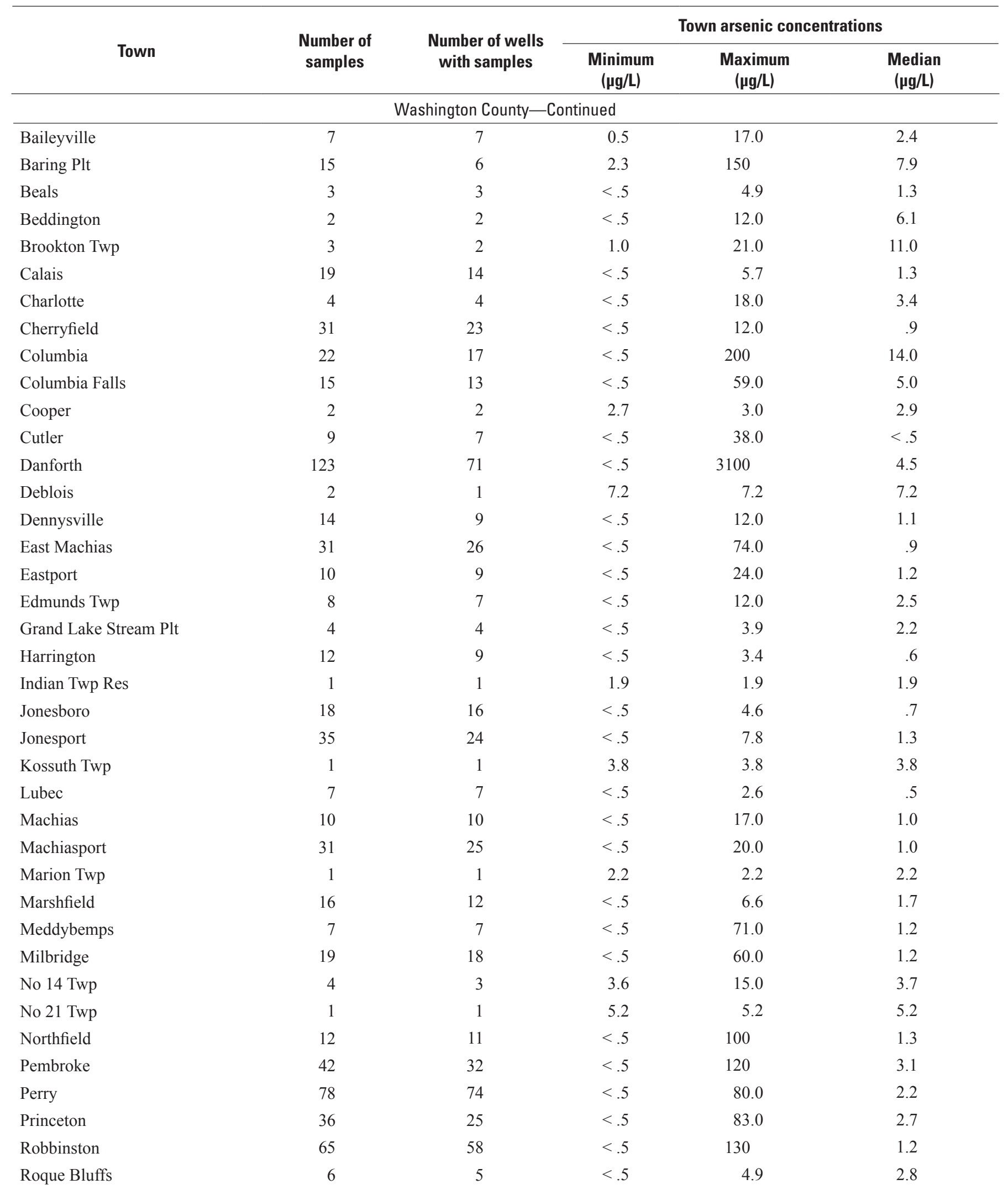


Appendix 2. Numbers of samples and wells with samples, by town, in Maine, and minimum, maximum, and median arsenic concentrations in each town with samples in the Maine Health and Environmental Testing Laboratory database, 2005-09.-Continued

[Statistics are calculated on wells, not total number of samples. See text for explanation of the treatment of multiple samples per well; $\mu \mathrm{g} / \mathrm{L}$, micrograms per liter; <, less than; Twp, township; Plt, plantation; UT, unincorporated territory]

\begin{tabular}{|c|c|c|c|c|c|}
\hline \multirow[b]{2}{*}{ Town } & \multirow{2}{*}{$\begin{array}{l}\text { Number of } \\
\text { samples }\end{array}$} & \multirow{2}{*}{$\begin{array}{l}\text { Number of wells } \\
\text { with samples }\end{array}$} & \multicolumn{3}{|c|}{ Town arsenic concentrations } \\
\hline & & & $\underset{(\mu g / L)}{\text { Minimum }}$ & $\begin{array}{c}\text { Maximum } \\
(\mu \mathrm{g} / \mathrm{L})\end{array}$ & $\begin{array}{c}\text { Median } \\
(\mu \mathrm{g} / \mathrm{L})\end{array}$ \\
\hline \multicolumn{6}{|c|}{ Washington County-Continued } \\
\hline Steuben & 27 & 22 & $<0.5$ & 3.2 & $<0.5$ \\
\hline T25 MD BPP & 1 & 1 & 13.0 & 13.0 & 13.0 \\
\hline T31 MD BPP & 1 & 1 & $<.5$ & $<.5$ & $<.5$ \\
\hline Topsfield & 5 & 2 & 1.0 & 1.1 & 1.1 \\
\hline Trescott Twp & 7 & 6 & $<.5$ & 130 & 1.1 \\
\hline Vanceboro & 2 & 2 & $<.5$ & .9 & .5 \\
\hline Wesley & 7 & 7 & $<.5$ & 170 & .7 \\
\hline Whiting & 17 & 16 & $<.5$ & 3.9 & .7 \\
\hline Whitneyville & 4 & 4 & $<.5$ & 5.2 & $<.5$ \\
\hline \multicolumn{6}{|c|}{ York County } \\
\hline Acton & 12 & 11 & $<0.5$ & 2.4 & $<0.5$ \\
\hline Alfred & 17 & 14 & $<.5$ & 2.9 & $<.5$ \\
\hline Arundel & 43 & 33 & $<.5$ & 37.0 & 4.7 \\
\hline Berwick & 29 & 27 & $<.5$ & 19.0 & 1.4 \\
\hline Biddeford & 21 & 18 & $<.5$ & 410 & 7.5 \\
\hline Buxton & 144 & 114 & $<.5$ & 270 & 5.2 \\
\hline Cornish & 12 & 8 & $<.5$ & 68.0 & 4.0 \\
\hline Dayton & 34 & 27 & $<.5$ & 84.0 & 1.2 \\
\hline Eliot & 55 & 39 & $<.5$ & 42.0 & 6.2 \\
\hline Hollis & 65 & 49 & $<.5$ & 260 & 2.1 \\
\hline Kennebunk & 23 & 20 & $<.5$ & 22.0 & $<.5$ \\
\hline Kennebunkport & 21 & 21 & $<.5$ & 9.6 & 1.6 \\
\hline Kittery & 15 & 14 & $<.5$ & 22.0 & 2.4 \\
\hline Lebanon & 20 & 19 & $<.5$ & 7.9 & .5 \\
\hline Limerick & 18 & 16 & $<.5$ & 36.0 & 1.3 \\
\hline Limington & 33 & 26 & $<.5$ & 85.0 & 1.4 \\
\hline Lyman & 60 & 46 & $<.5$ & 12.0 & $<.5$ \\
\hline Newfield & 18 & 16 & $<.5$ & 28.0 & 9.0 \\
\hline North Berwick & 15 & 14 & $<.5$ & 45.0 & 5.1 \\
\hline Ogunquit & 1 & 1 & 2.0 & 2.0 & 2.0 \\
\hline Old Orchard Beach & 4 & 4 & $<.5$ & .7 & $<.5$ \\
\hline Parsonsfield & 27 & 20 & $<.5$ & 17.0 & 1.4 \\
\hline Saco & 84 & 63 & $<.5$ & 350 & 3.2 \\
\hline Sanford & 24 & 21 & $<.5$ & 18.0 & $<.5$ \\
\hline Shapleigh & 11 & 10 & $<.5$ & 31.0 & 2.1 \\
\hline South Berwick & 17 & 16 & $<.5$ & 24.0 & 1.1 \\
\hline Waterboro & 57 & 35 & $<.5$ & 51.0 & .6 \\
\hline Wells & 44 & 31 & $<.5$ & 14.0 & 1.0 \\
\hline York & 41 & 38 & $<.5$ & 35.0 & .6 \\
\hline
\end{tabular}


Appendix 3. Exceedence percentages for towns with more than 20 wells sampled for arsenic, from samples in the Maine Health and Environmental Testing Laboratory database, 2005-09.

[ $\mu \mathrm{g} / \mathrm{L}$, micrograms per liter; As, arsenic]

\begin{tabular}{|c|c|c|c|c|c|}
\hline Town & $\begin{array}{c}\text { Number of } \\
\text { wells sampled }\end{array}$ & $\begin{array}{l}\text { Percentage of wells } \\
\text { exceeding } \\
10 \mu \mathrm{g} / \mathrm{L} \mathrm{As}\end{array}$ & $\begin{array}{l}\text { Percentage of wells } \\
\text { exceeding } \\
50 \mu \mathrm{g} / \mathrm{L} \mathrm{As}\end{array}$ & $\begin{array}{l}\text { Percentage of wells } \\
\text { exceeding } \\
100 \mu \mathrm{g} / \mathrm{L} \mathrm{As}\end{array}$ & $\begin{array}{c}\text { Percentage of wells } \\
\text { exceeding } \\
500 \mu \mathrm{g} / \mathrm{L} \mathrm{As}\end{array}$ \\
\hline \multicolumn{6}{|c|}{ Androscoggin County } \\
\hline Auburn & 37 & 32 & 3 & 3 & 0 \\
\hline Durham & 43 & 0 & 0 & 0 & 0 \\
\hline Greene & 43 & 37 & 9 & 2 & 0 \\
\hline Leeds & 27 & 26 & 4 & 4 & 0 \\
\hline Lisbon & 38 & 11 & 0 & 0 & 0 \\
\hline Livermore & 20 & 0 & 0 & 0 & 0 \\
\hline Minot & 32 & 34 & 3 & 3 & 0 \\
\hline Poland & 69 & 9 & 0 & 0 & 0 \\
\hline Sabattus & 62 & 18 & 2 & 0 & 0 \\
\hline Turner & 95 & 18 & 2 & 0 & 0 \\
\hline \multicolumn{6}{|c|}{ Aroostook County } \\
\hline Presque Isle & 27 & 0 & 0 & 0 & 0 \\
\hline \multicolumn{6}{|c|}{ Cumberland County } \\
\hline Bridgton & 43 & 0 & 0 & 0 & 0 \\
\hline Brunswick & 93 & 9 & 1 & 0 & 0 \\
\hline Casco & 36 & 0 & 0 & 0 & 0 \\
\hline Cumberland & 84 & 8 & 1 & 0 & 0 \\
\hline Falmouth & 53 & 11 & 0 & 0 & 0 \\
\hline Freeport & 61 & 7 & 2 & 2 & 0 \\
\hline Gorham & 218 & 57 & 22 & 8 & 0 \\
\hline Gray & 111 & 27 & 5 & 1 & 0 \\
\hline Harpswell & 87 & 5 & 0 & 0 & 0 \\
\hline Harrison & 29 & 0 & 0 & 0 & 0 \\
\hline Naples & 79 & 0 & 0 & 0 & 0 \\
\hline New Gloucester & 75 & 16 & 1 & 0 & 0 \\
\hline North Yarmouth & 44 & 9 & 0 & 0 & 0 \\
\hline Portland & 22 & 14 & 0 & 0 & 0 \\
\hline Raymond & 52 & 2 & 0 & 0 & 0 \\
\hline Scarborough & 61 & 48 & 10 & 3 & 0 \\
\hline Sebago & 26 & 0 & 0 & 0 & 0 \\
\hline Standish & 120 & 23 & 8 & 6 & 0 \\
\hline Windham & 81 & 19 & 6 & 1 & 0 \\
\hline \multicolumn{6}{|c|}{ Franklin County } \\
\hline Carrabassett Valley & 20 & 25 & 0 & 0 & 0 \\
\hline Farmington & 35 & 0 & 0 & 0 & 0 \\
\hline New Sharon & 24 & 8 & 0 & 0 & 0 \\
\hline Rangeley & 37 & 35 & 8 & 5 & 0 \\
\hline \multicolumn{6}{|c|}{ Hancock County } \\
\hline Bar Harbor & 57 & 18 & 2 & 2 & 0 \\
\hline Blue Hill & 75 & 57 & 15 & 11 & 3 \\
\hline
\end{tabular}


Appendix 3. Exceedence percentages for towns with more than 20 wells sampled for arsenic, from samples in the Maine Health and Environmental Testing Laboratory database, 2005-09.-Continued

[ $\mu \mathrm{g} / \mathrm{L}$, micrograms per liter; As, arsenic]

\begin{tabular}{|c|c|c|c|c|c|}
\hline Town & $\begin{array}{c}\text { Number of } \\
\text { wells sampled }\end{array}$ & $\begin{array}{l}\text { Percentage of wells } \\
\text { exceeding } \\
10 \mu \mathrm{g} / \mathrm{L} \mathrm{As}\end{array}$ & $\begin{array}{l}\text { Percentage of wells } \\
\text { exceeding } \\
50 \mu \mathrm{g} / \mathrm{L} \mathrm{As}\end{array}$ & $\begin{array}{l}\text { Percentage of wells } \\
\text { exceeding } \\
100 \mu \mathrm{g} / \mathrm{L} \mathrm{As}\end{array}$ & $\begin{array}{l}\text { Percentage of wells } \\
\text { exceeding } \\
500 \mu \mathrm{g} / \mathrm{L} \mathrm{As}\end{array}$ \\
\hline \multicolumn{6}{|c|}{ Hancock County-Continued } \\
\hline Brooklin & 32 & 3 & 0 & 0 & 0 \\
\hline Brooksville & 40 & 15 & 3 & 0 & 0 \\
\hline Bucksport & 31 & 10 & 3 & 0 & 0 \\
\hline Dedham & 40 & 28 & 0 & 0 & 0 \\
\hline Deer Isle & 56 & 5 & 0 & 0 & 0 \\
\hline Ellsworth & 219 & 37 & 11 & 5 & 0 \\
\hline Franklin & 31 & 16 & 3 & 3 & 0 \\
\hline Gouldsboro & 82 & 1 & 0 & 0 & 0 \\
\hline Hancock & 45 & 20 & 2 & 0 & 0 \\
\hline Lamoine & 44 & 7 & 0 & 0 & 0 \\
\hline Mount Desert & 35 & 0 & 0 & 0 & 0 \\
\hline Orland & 40 & 35 & 3 & 3 & 0 \\
\hline Penobscot & 31 & 32 & 6 & 3 & 0 \\
\hline Sedgwick & 33 & 33 & 12 & 9 & 0 \\
\hline Stonington & 21 & 0 & 0 & 0 & 0 \\
\hline Sullivan & 94 & 15 & 2 & 1 & 0 \\
\hline Surry & 120 & 51 & 33 & 23 & 2 \\
\hline Tremont & 24 & 8 & 0 & 0 & 0 \\
\hline Trenton & 44 & 39 & 5 & 0 & 0 \\
\hline \multicolumn{6}{|c|}{ Kennebec County } \\
\hline Albion & 24 & 33 & 0 & 0 & 0 \\
\hline Augusta & 151 & 25 & 5 & 1 & 0 \\
\hline Belgrade & 95 & 33 & 2 & 1 & 0 \\
\hline Chelsea & 75 & 3 & 1 & 1 & 0 \\
\hline China & 80 & 14 & 3 & 0 & 0 \\
\hline Farmingdale & 31 & 16 & 3 & 0 & 0 \\
\hline Fayette & 44 & 11 & 2 & 0 & 0 \\
\hline Gardiner & 28 & 4 & 4 & 0 & 0 \\
\hline Litchfield & 110 & 42 & 15 & 5 & 0 \\
\hline Manchester & 111 & 62 & 19 & 3 & 0 \\
\hline Monmouth & 111 & 45 & 14 & 6 & 0 \\
\hline Mount Vernon & 86 & 35 & 5 & 1 & 0 \\
\hline Oakland & 71 & 24 & 1 & 0 & 0 \\
\hline Pittston & 95 & 1 & 0 & 0 & 0 \\
\hline Readfield & 129 & 49 & 12 & 3 & 0 \\
\hline Rome & 22 & 14 & 0 & 0 & 0 \\
\hline Sidney & 123 & 30 & 6 & 0 & 0 \\
\hline Vassalboro & 60 & 35 & 2 & 2 & 0 \\
\hline Wayne & 50 & 8 & 0 & 0 & 0 \\
\hline West Gardiner & 123 & 24 & 5 & 0 & 0 \\
\hline
\end{tabular}


Appendix 3. Exceedence percentages for towns with more than 20 wells sampled for arsenic, from samples in the Maine Health and Environmental Testing Laboratory database, 2005-09.-Continued

[ $\mu \mathrm{g} / \mathrm{L}$, micrograms per liter; As, arsenic]

\begin{tabular}{|c|c|c|c|c|c|}
\hline Town & $\begin{array}{c}\text { Number of } \\
\text { wells sampled }\end{array}$ & $\begin{array}{c}\text { Percentage of wells } \\
\text { exceeding } \\
10 \mu \mathrm{g} / \mathrm{L} \mathrm{As}\end{array}$ & $\begin{array}{c}\text { Percentage of wells } \\
\text { exceeding } \\
50 \mu \mathrm{g} / \mathrm{L} \mathrm{As}\end{array}$ & $\begin{array}{c}\text { Percentage of wells } \\
\text { exceeding } \\
100 \mu \mathrm{g} / \mathrm{L} \mathrm{As}\end{array}$ & $\begin{array}{c}\text { Percentage of wells } \\
\text { exceeding } \\
500 \mu \mathrm{g} / \mathrm{L} \mathrm{As}\end{array}$ \\
\hline \multicolumn{6}{|c|}{ Kennebec County-Continued } \\
\hline Windsor & 67 & 10 & 0 & 0 & 0 \\
\hline Winslow & 21 & 10 & 0 & 0 & 0 \\
\hline Winthrop & 130 & 46 & 12 & 2 & 0 \\
\hline Rockport & 22 & 36 & 18 & 9 & 0 \\
\hline Saint George & 27 & 0 & 0 & 0 & 0 \\
\hline South Thomaston & 21 & 14 & 5 & 0 & 0 \\
\hline Union & 36 & 33 & 8 & 3 & 0 \\
\hline Boothbay & 52 & 4 & 0 & 0 & 0 \\
\hline Bristol & 48 & 4 & 0 & 0 & 0 \\
\hline Damariscotta & 23 & 0 & 0 & 0 & 0 \\
\hline Dresden & 57 & 5 & 0 & 0 & 0 \\
\hline Edgecomb & 35 & 0 & 0 & 0 & 0 \\
\hline Jefferson & 76 & 22 & 3 & 0 & 0 \\
\hline Newcastle & 29 & 0 & 0 & 0 & 0 \\
\hline Nobleboro & 30 & 3 & 0 & 0 & 0 \\
\hline South Bristol & 32 & 0 & 0 & 0 & 0 \\
\hline Dixfield & 23 & 0 & 0 & 0 & 0 \\
\hline Norway & 32 & 0 & 0 & 0 & 0 \\
\hline Oxford & 24 & 0 & 0 & 0 & 0 \\
\hline Peru & 20 & 10 & 0 & 0 & 0 \\
\hline Rumford & 20 & 5 & 0 & 0 & 0 \\
\hline Woodstock & 20 & 5 & 0 & 0 & 0 \\
\hline \multicolumn{6}{|c|}{ Penobscot County } \\
\hline Bangor & 32 & 9 & 0 & 0 & 0 \\
\hline Carmel & 23 & 13 & 0 & 0 & 0 \\
\hline Chester & 27 & 4 & 0 & 0 & 0 \\
\hline Corinna & 20 & 5 & 0 & 0 & 0 \\
\hline Corinth & 37 & 8 & 0 & 0 & 0 \\
\hline Eddington & 25 & 0 & 0 & 0 & 0 \\
\hline Enfield & 23 & 22 & 4 & 4 & 0 \\
\hline Glenburn & 50 & 12 & 0 & 0 & 0 \\
\hline
\end{tabular}


Appendix 3. Exceedence percentages for towns with more than 20 wells sampled for arsenic, from samples in the Maine Health and Environmental Testing Laboratory database, 2005-09.-Continued

[ $\mu \mathrm{g} / \mathrm{L}$, micrograms per liter; As, arsenic]

\begin{tabular}{|c|c|c|c|c|c|}
\hline Town & $\begin{array}{c}\text { Number of } \\
\text { wells sampled }\end{array}$ & $\begin{array}{l}\text { Percentage of wells } \\
\text { exceeding } \\
10 \mu \mathrm{g} / \mathrm{L} \mathrm{As}\end{array}$ & $\begin{array}{l}\text { Percentage of wells } \\
\text { exceeding } \\
50 \mu \mathrm{g} / \mathrm{L} \mathrm{As}\end{array}$ & $\begin{array}{c}\text { Percentage of wells } \\
\text { exceeding } \\
100 \mu \mathrm{g} / \mathrm{L} \mathrm{As}\end{array}$ & $\begin{array}{l}\text { Percentage of wells } \\
\text { exceeding } \\
500 \mu \mathrm{g} / \mathrm{L} \mathrm{As}\end{array}$ \\
\hline \multicolumn{6}{|c|}{ Penobscot County—Continued } \\
\hline Hampden & 47 & 4 & 0 & 0 & 0 \\
\hline Hermon & 60 & 8 & 0 & 0 & 0 \\
\hline Holden & 55 & 7 & 0 & 0 & 0 \\
\hline Lagrange & 25 & 24 & 0 & 0 & 0 \\
\hline Levant & 31 & 3 & 3 & 0 & 0 \\
\hline Lincoln & 40 & 10 & 0 & 0 & 0 \\
\hline Medway & 34 & 3 & 0 & 0 & 0 \\
\hline Old Town & 28 & 7 & 4 & 0 & 0 \\
\hline Orrington & 31 & 0 & 0 & 0 & 0 \\
\hline Plymouth & 44 & 11 & 0 & 0 & 0 \\
\hline \multicolumn{6}{|c|}{ Piscataquis County } \\
\hline Dover-Foxcroft & 34 & 9 & 0 & 0 & 0 \\
\hline \multicolumn{6}{|c|}{ Sagadahoc County } \\
\hline Arrowsic & 20 & 0 & 0 & 0 & 0 \\
\hline Bowdoin & 39 & 15 & 3 & 0 & 0 \\
\hline Bowdoinham & 37 & 3 & 0 & 0 & 0 \\
\hline Georgetown & 40 & 3 & 0 & 0 & 0 \\
\hline Phippsburg & 69 & 6 & 0 & 0 & 0 \\
\hline Richmond & 47 & 0 & 0 & 0 & 0 \\
\hline Topsham & 35 & 6 & 0 & 0 & 0 \\
\hline West Bath & 26 & 4 & 0 & 0 & 0 \\
\hline Woolwich & 63 & 3 & 3 & 3 & 2 \\
\hline \multicolumn{6}{|c|}{ Somerset County } \\
\hline Canaan & 44 & 16 & 0 & 0 & 0 \\
\hline Fairfield & 24 & 33 & 0 & 0 & 0 \\
\hline Madison & 65 & 12 & 0 & 0 & 0 \\
\hline Palmyra & 20 & 10 & 0 & 0 & 0 \\
\hline Skowhegan & 34 & 32 & 12 & 6 & 0 \\
\hline \multicolumn{6}{|c|}{ Waldo County } \\
\hline Belfast & 42 & 17 & 2 & 0 & 0 \\
\hline Brooks & 36 & 3 & 3 & 0 & 0 \\
\hline Liberty & 23 & 0 & 0 & 0 & 0 \\
\hline Lincolnville & 30 & 27 & 10 & 7 & 0 \\
\hline Montville & 26 & 0 & 0 & 0 & 0 \\
\hline Northport & 35 & 37 & 14 & 6 & 0 \\
\hline Palermo & 28 & 4 & 0 & 0 & 0 \\
\hline Prospect & 26 & 8 & 0 & 0 & 0 \\
\hline Stockton Springs & 23 & 9 & 0 & 0 & 0 \\
\hline Unity & 26 & 19 & 8 & 4 & 0 \\
\hline Winterport & 41 & 2 & 0 & 0 & 0 \\
\hline
\end{tabular}


Appendix 3. Exceedence percentages for towns with more than 20 wells sampled for arsenic, from samples in the Maine Health and Environmental Testing Laboratory database, 2005-09.-Continued

[ $\mu \mathrm{g} / \mathrm{L}$, micrograms per liter; As, arsenic]

\begin{tabular}{|c|c|c|c|c|c|}
\hline Town & $\begin{array}{c}\text { Number of } \\
\text { wells sampled }\end{array}$ & $\begin{array}{c}\text { Percentage of wells } \\
\text { exceeding } \\
10 \mu \mathrm{g} / \mathrm{L} \mathrm{As}\end{array}$ & $\begin{array}{l}\text { Percentage of wells } \\
\text { exceeding } \\
50 \mu \mathrm{g} / \mathrm{L} \mathrm{As}\end{array}$ & $\begin{array}{c}\text { Percentage of wells } \\
\text { exceeding } \\
100 \mu \mathrm{g} / \mathrm{L} \mathrm{As}\end{array}$ & $\begin{array}{l}\text { Percentage of wells } \\
\text { exceeding } \\
500 \mu \mathrm{g} / \mathrm{L} \mathrm{As}\end{array}$ \\
\hline \multicolumn{6}{|c|}{ Washington County } \\
\hline Addison & 21 & 14 & 0 & 0 & 0 \\
\hline Cherryfield & 23 & 4 & 0 & 0 & 0 \\
\hline Danforth & 71 & 42 & 20 & 11 & 8 \\
\hline East Machias & 26 & 12 & 8 & 0 & 0 \\
\hline Jonesport & 24 & 0 & 0 & 0 & 0 \\
\hline Machiasport & 25 & 12 & 0 & 0 & 0 \\
\hline Pembroke & 32 & 28 & 6 & 3 & 0 \\
\hline Perry & 74 & 20 & 3 & 0 & 0 \\
\hline Princeton & 25 & 24 & 8 & 0 & 0 \\
\hline Robbinston & 58 & 9 & 5 & 2 & 0 \\
\hline Steuben & 22 & 0 & 0 & 0 & 0 \\
\hline \multicolumn{6}{|c|}{ York County } \\
\hline Arundel & 33 & 30 & 0 & 0 & 0 \\
\hline Berwick & 27 & 7 & 0 & 0 & 0 \\
\hline Buxton & 114 & 41 & 11 & 5 & 0 \\
\hline Dayton & 27 & 33 & 11 & 0 & 0 \\
\hline Eliot & 39 & 38 & 0 & 0 & 0 \\
\hline Hollis & 49 & 35 & 16 & 6 & 0 \\
\hline Kennebunk & 20 & 10 & 0 & 0 & 0 \\
\hline Kennebunkport & 21 & 0 & 0 & 0 & 0 \\
\hline Limington & 26 & 27 & 4 & 0 & 0 \\
\hline Lyman & 46 & 2 & 0 & 0 & 0 \\
\hline Parsonsfield & 20 & 10 & 0 & 0 & 0 \\
\hline Saco & 63 & 30 & 10 & 5 & 0 \\
\hline Sanford & 21 & 5 & 0 & 0 & 0 \\
\hline Waterboro & 35 & 17 & 3 & 0 & 0 \\
\hline Wells & 31 & 3 & 0 & 0 & 0 \\
\hline York & 38 & 5 & 0 & 0 & 0 \\
\hline
\end{tabular}


Prepared by the Pembroke and West Trenton Publishing Service Centers.

For more information concerning this report, contact:

Director

U.S. Geological Survey

Maine Water Science Center

196 Whitten Road

Augusta, ME 04330

dc_me@usgs.gov

or visit our Web site at:

http://me.water.usgs.gov 
